\title{
Bambus nativos (Poaceae, Bambusoideae) no Parque Estadual das Fontes do Ipiranga, São Paulo, SP, Brasil
}

\author{
Regina Tomoko Shirasuna ${ }^{2,3}$ e Tarciso de Sousa Filgueiras ${ }^{2}$
}

Recebido: 10.05.2012; aceito: 11.04.2013

\begin{abstract}
Native bamboos (Poaceae, Bambusoideae) in the Parque Estadual das Fontes do Ipiranga, São Paulo, São Paulo State, Brazil). A floristic survey of the native bamboos in Parque Estadual das Fontes do Ipiranga (PEFI), São Paulo, São Paulo State, Brazil is presented. Forty-one field excursions were undertaken (January 2010 through September 2011). Identification keys, descriptions, illustrations, distribution, phenology, popular names and an evaluation of the conservation status of each species are provided. Five genera and 17 species were recorded. The genus with the highest number of species is Merostachys (9 spp.), followed by Chusquea (3) and Olyra (3). Aulonemia and Parodiolyra are both represented by a single species. Merostachys burmanii, M. scandens, M. skvortzovii and Olyra loretensis are considered endangered in the São Paulo State.
\end{abstract}

Key words: Bambuseae, conservation, Gramineae, Olyreae, taxonomy

RESUMO - (Bambus nativos (Poaceae, Bambusoideae) no Parque Estadual das Fontes do Ipiranga, São Paulo, SP, Brasil). O presente trabalho apresenta a composição florística dos bambus nativos do Parque Estadual das Fontes do Ipiranga (PEFI), São Paulo, SP, Brasil. Foram feitas 41 excursões de coleta (janeiro/2010 a setembro/2011). São apresentadas chaves de identificação, descrições padronizadas, ilustrações, distribuição e ecologia, nomes populares, fenologia e status conservacionista para cada espécie. Bambusoideae está representada no Parque por cinco gêneros e 17 espécies nativas. $\mathrm{O}$ gênero com maior número de espécies é Merostachys (9 spp.), seguido de Chusquea (3), Olyra (3), Aulonemia e Parodiolyra com uma espécie cada. Merostachys burmanii, M. scandens, M. skvortzovii e Olyra loretensis são consideradas ameaçadas de extinção no Estado.

Palavras-chave: Bambuseae, conservação, Gramineae, Olyreae, taxonomia

\section{Introdução}

Poaceae (Gramineae) é uma das famílias de angiospermas mais amplamente distribuídas em todo o mundo. Cerca de $40 \%$ da cobertura vegetal no mundo é composta principalmente por gramíneas (Gibson et al. 2009). É a quarta maior família em número de espécies no mundo, totalizando ca. 668 gêneros e 11.160 espécies (Stevens 2012). No Brasil registra-se a ocorrência de 210 gêneros e 1.413 espécies de Poaceae (Filgueiras et al. 2012).

A família é considerada um grupo monofilético (Stevens 2012). Pertence às monocotiledôneas, clado Commelinídeas, ordem Poales (APG III 2009). De acordo com o Grass Phylogeny Work Group (GPWG 2001) são reconhecidas 13 subfamílias: Anomochlooideae, Pharoideae,
Puelioideae, Bambusoideae, Ehrhartoideae, Pooideae, Aristidoideae, Arundinoideae, Chloridoideae, Centothecoideae, Panicoideae, Danthonioideae e Micrairoideae.

A subfamília Bambusoideae é caracterizada pelas seguintes sinapomorfias: plantas perenes (raro anuais), hábito rizomatoso, ramificação simples ou complexa, folhas pseudopecioladas, mesofilo com células invaginantes fortemente assimétricas, associadas a células fusóides e células buliformes, tricomas bicelulares (micropelos) alongados, com paredes delgadas (Judziewicz et al. 1999), folhas embrionárias com margens que se sobrepõem, plântula sem a primeira folha (Stevens 2012).

A subfamília reune três clados, correspondendo às tribos Olyreae (bambus herbáceos), Bambuseae (bambus lignificados) e Arundinarieae (bambus

1. Parte da Dissertação de Mestrado da primeira Autora

2. Instituto de Botânica, Caixa Postal 68041, 04045-972 São Paulo, SP, Brasil

3. Autor para correspondência: regina.shirasuna@hotmail.com 
lignificados de clima temperado) (Sungkaew et al. 2009). Está representada no Brasil por ca. 34 gêneros e 252 espécies nativas, representando $16,6 \%$ de todas as espécies de bambus do mundo (Filgueiras et al. 2012). Desse total, nove gêneros e 159 espécies são endêmicos (Filgueiras et al. 2012).

$\mathrm{O}$ presente trabalho visou contribuir para o estudo da composição florística dos bambus do PEFI, ampliando o conhecimento sobre sua taxonomia, distribuição e o estado de conservação, colaborando, dessa forma, para a conclusão dos estudos florísticos da família Poaceae do Parque e atualizando o conhecimento da flora de Poaceae no Estado de São Paulo.

\section{Material e métodos}

Caracterização da área de estudos - O presente levantamento foi realizado no Parque Estadual das Fontes do Ipiranga (PEFI - 526,38 ha.), situado na capital do Estado de São Paulo (233' $08^{\prime \prime}-23^{\circ} 40^{\prime} 18^{\prime \prime S}$ E $\left.46^{\circ} 36^{\prime} 48^{\prime \prime}-46^{\circ} 38^{\prime} 00^{\prime \prime} \mathrm{W}\right)$ com altitudes médias entre 770 e 825 m.s.m. (Nastri et al. 1992). O clima é do tipo Cwb, pela classificação de Köppen, com temperatura média anual de $19,1{ }^{\circ} \mathrm{C}$ e precipitação média anual de $1.540 \mathrm{~mm}$ (Santos \& Funari 2002). Está situada na sub-zona das Colinas de São Paulo, ou seja, um sistema de colinas pequenas com espigões locais, que se desenvolvem sobre sedimentos da bacia São Paulo e áreas pré-cambrianas (Ponçano et al. 1981). A vegetação é caracterizada como Mata Atlântica (Pivello \& Peccinini 2002, IBGE \& MMA 2004), com ocorrência de espécies características tanto da floresta ombrófila densa quanto de espécies da floresta estacional semidecidual, embora, haja maior similaridade com a floresta ombrófila do que com as florestas estacionais do interior (Struffaldi-De-Vuono et al. 1984, Gomes 1992, 1998, Mantovani 1993, Aragaki 1997); é uma vegetação secundária em processo de regeneração (Barros et al. 2002).

Segundo o estudo realizado pelo Plano de Manejo do PEFI (Santos 2006, figura 1) foram reconhecidas seis categorias dos tipos vegetacionais quanto à estrutura, composição florística e localização na área. Embora o sistema de classificação do Plano de Manejo apresente controvérsias, foi adotado no presente trabalho por ser uma publicação oficial do Estado.

Coleta de material botânico e tratamento taxonômico A trilha principal que atravessa o Parque como também as trilhas secundárias e a que o circunda foram percorridas, além de caminhadas aleatórias pela mata tentando-se cobrir outras áreas do PEFI. Para as coletas foram seguidas as normas propostas por Soderstrom \& Young (1983) e Mori et al. (1989). As exsicatas foram depositadas no Herbário SP e as duplicatas distribuídas para outros herbários.

As coordenadas geográficas foram coletadas com o aparelho de GPS Garmin 60CSX.

Para o mapeamento das espécies utilizou-se do programa Arc Gis 10.0, adotando-se o Índice Internacional de Nomenclatura para o sistema UTM: MC:-45 ZONA : 23-WGS 84.

As espécies foram identificadas com base em literatura especializada, consulta aos especialistas L.G. Clark e P.L. Viana e visitas pessoais aos seguintes herbários paulistas: ESA, PMSP, SP, SPF, SPSF e UEC. Foram ainda analisadas as listas de exsicatas do site da internet http://splink.cria.org.br, provenientes dos seguintes herbários paulistas: BOTU, IAC, HRCB, HSJRP e HUMCA. Alguns herbários internacionais também foram consultados via internet: MO, NY e US. Várias exsicatas foram analisadas por empréstimos dos herbários: IAC, MO e NY. Os acrônimos dos herbários são citados de acordo com o Index Herbariorum (Thiers 2012).

As descrições da subfamília e gêneros foram adaptadas de Calderón \& Soderstrom (1980), Sendulsky (1992, 1995, 2001), Judziewicz, et al. (1999), Longhi-Wagner et al. (2001). As descrições das espécies foram baseadas nos materiais examinados. A terminologia adotada nas descrições é a de Soderstrom \& Young (1983) e Longhi-Wagner et al. (2001). As medidas das panículas foram tomadas sem os pedúnculos. Todas as partes da planta foram analisadas detalhadamente com o auxílio de estereomicroscópio, e as medidas feitas com régua e paquímetro digital.

A distribuição geográfica das espécies dentro da área de estudos foi baseada nos dados das etiquetas das exsicatas examinadas e nos dados de campo.

O estado de conservação das espécies nativas do Parque tomou como base os critérios descritos no Livro Vermelho das Espécies Vegetais Ameaçadas do Estado de São Paulo (Mamede et al. 2007).

Foram utilizadas as seguintes abreviações: ca. (cerca de), Cien Tec (Centro de Ciência e Tecnologia da Universidade de São Paulo), fl. (material fértil), IBt (Instituto de Botânica de São Paulo, m.s.m. (metralis supra mare: metros acima do nível do mar), s.a. (sine anno, sem data), s.col. (sem coletor), s.n. (sem número), UCs (unidades de conservação), veg. (material vegetativo). 


\section{Parque Estadual das Fontes do Ipiranga}

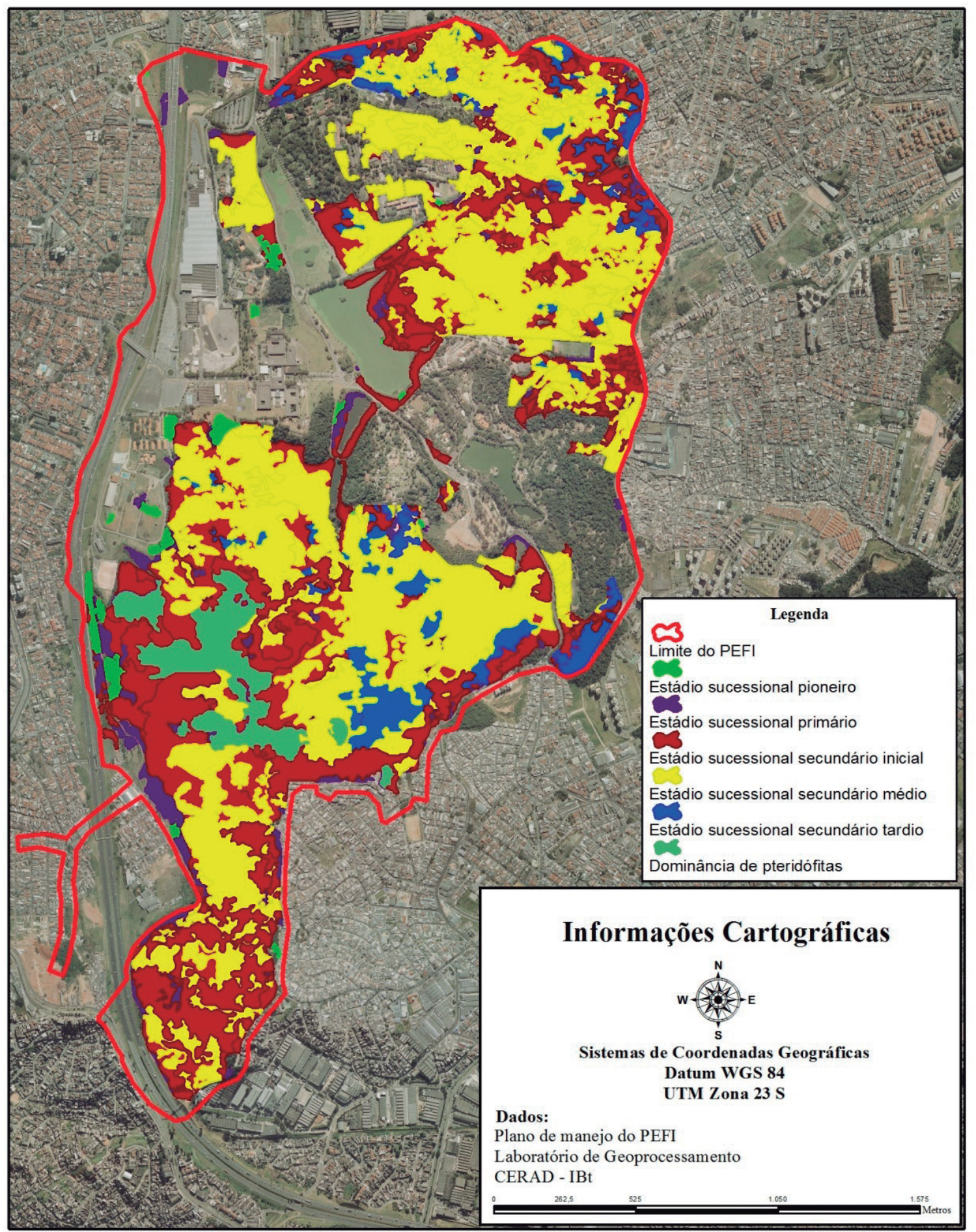

Figura 1. Estádios sucessionais do Parque Estadual das Fontes do Ipiranga, São Paulo, SP, Brasil, segundo o Plano de Manejo (2005).

Figure 1. Succesional vegetational stages of Parque Estadual das Fontes do Ipiranga, São Paulo, São Paulo State, Brazil, according to the Management Plan (2005). 
Adotou-se o sistema de classificação Stevens (2012). Para o gênero Chusquea seguiu-se a classificação de Fisher et al. (2009) e para demais gêneros seguiu-se Filgueiras et al. (2012).

As espécies foram ilustradas incluindo partes vegetativas e florais pelo ilustrador Klei Sousa utilizandose de câmara-clara acoplada ao estereomicroscópio, finalizando com cobertura em nanquin.

\section{Resultados e Discussão}

Foram realizadas 41 excursões de coletas durante o período de janeiro de 2010 a setembro de 2011, resultando 47 coleções; além disso, foram examinadas 514 coleções provenientes de seis herbários paulistas, totalizando 561 espécimes examinados.

Bambusoideae está representada no Parque por cinco gêneros e 17 espécies nativas (figura 2).

Chave para identificação dos gêneros de Bambusoideae nativos no PEFI

1. Plantas herbáceas, subarbustivas, sublignificadas; folhas dos ramos sem lígula externa; espiguetas unissexuadas

2. Plantas geralmente sem ramificações nos nós do colmo, ocasionalmente com 1 ramificação em direção aoápice; espiguetas femininas maiores que as masculinas; desarticulação das espiguetas femininas acima das glumas 4. Olyra

2. Plantas com 1-3 ramificações basais nos nós do colmo; espiguetas femininas do mesmo comprimento que as masculinas; desarticulação das espiguetas femininas abaixo das glumas

\section{Parodiolyra (5.1. P. micrantha)}

1. Plantas arbustivas a arbóreas, escandentes, lignificadas; folhas dos ramos com lígula externa, espiguetas bissexuadas

3. Plantas com 1 ramo nos nós do colmo; sinflorescência em panícula contraída 1. Aulonemia (1.1. A. aristulata)

3. Plantas com 3-300 ramos nos nós do colmo; sinflorescênciaemracemopectinado ou panícula laxa a contraída

4. Entrenó do colmo fistuloso; 3-300 ramos subiguais em cada nó; ramificação apsidada; sinflorescência em racemo . 2. Merostachys

4. Entrenó do colmo sólido; 3-60 ramos, ramificação constelada; sinflorescência em panícula 3. Chusquea

\section{Tribo Bambuseae Nees}

A tribo Bambuseae está representada no PEFI por duas subtribos: Arthrostylidiinae Soderstrom \& Ellis, com os gêneros Aulonemia e Merostachys, e Chusqueinae Soderstrom \& Ellis, com o gênero Chusquea.

1. Aulonemia Goudot, Ann. Sci Nat., Bot., ser. 3, 5: 75. 1846.

Caracteres diagnósticos: ramificação intravaginal, complemento de ramo com um único ramo (às vezes com nova ramificação em padrão dicotômico), bainha das folhas dos complementos de ramos com fímbrias apicais, raro nulas, pseudopecíolo presente, sinflorescência panícula-espiciforme, laxa, raro contraída, determinada, terminal, espiguetas bissexuadas, basítonas, glumas 2(-5-7), entrenó de ráquila presente; antécios férteis 1-10, antécio apical reduzido ou desenvolvido 1 , lema 1; pálea 1 , rudimentar ou nula; estames 3; estigmas 2; lodículas 3 , cariopse nucoide, hilo linear.

O gênero Aulonemia é composto por 38 espécies (Judziewicz et al. 2000, Clark et al. 2007) com distribuição Neotropical. São reconhecidas 14 espécies de ocorrência para o Brasil (Viana 2010a, Viana 2012). No PEFI verificou-se a ocorrência de uma única espécie, Aulonemia aristulata (Döll) McClure.

\subsection{Aulonemia aristulata (Dö1l) McClure,}

Smithsonian Contr. Bot. 9: 56. 1973.

Figura 3

Rizoma paquimorfo, pescoço curto. Colmos 0,5-8,5 m compr., eretos, decumbentes a escandentes, formando densas moitas sobre a vegetação; 1-3 mm diâm., entrenós 4,5-14,5 cm compr., fistulosos, glabros ou pubérulos próximo à região nodal, verdes a castanhos, maculados ou não. Linha nodal verde-acastanhada, glabra, anel supranodal conspícuo. Folhas do colmo: sem distinção nítida entre as folhas dos ramos. Folhas dos complementos de ramos: bainha, glabra a hirsuta, verde a castanho-clara, às vezes maculada, margem lisa a finamente ciliolada; fímbrias apicais 2-10(-16) mm compr., tardiamente caducas, achatadas, livres, eretas na base e pouco onduladas no ápice, antrorso-escabras, estramíneas a vináceas; lígula externa 0,1-0,2 mm, membranoso-ciliolada; lígula interna $0,1-0,3 \mathrm{~mm}$ membranoso-ciliolada; pseudopecíolo 1-2 mm compr., face adaxial pubescente a hirsuta, face abaxial glabra a hirsuta; lâmina 4,5-18,5(-21,5) ×0,6-2,3(-3,3) cm, face 


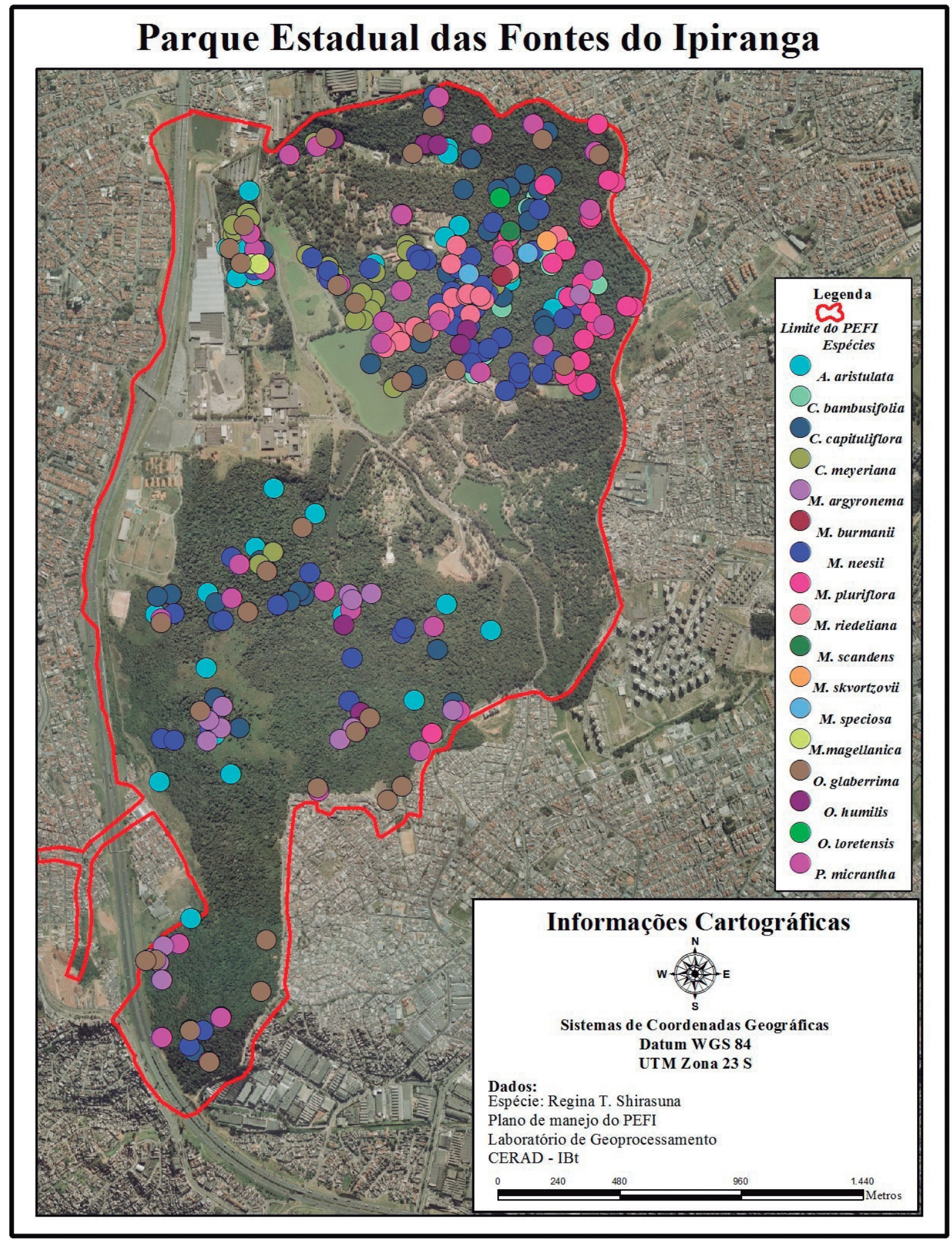

Figura 2. Distribuição conhecida das 17 espécies nativas da subfamília Bambusoideae no Parque Estadual das Fontes do Ipiranga, São Paulo, SP, Brasil.

Figure 2. Known distribution of the 17 native species in subfamily Bambusoideae of the Parque Estadual das Fontes do Ipiranga, São Paulo, São Paulo State, Brazil. 
adaxial glabra a pilosa, geralmente escabra próximo a uma das margens, face abaxial glabra a densamente pilosa, concolor, base assimétrica, arredondada, ápice acuminado, margens antrorso-escabras. Panículas 20-35 cm compr., oblonga a piramidal, laxa. Espiguetas $12-35 \mathrm{~mm}$, linear a linear-lanceoladas, glumas 2, antécios férteis 3-7, antécio apical rudimentar 1; gluma I, 5-6 mm compr., 3-5(-7)-nervada, oblongo-lanceolada, aristada a mucronada, arista 1-1,5 mm compr., raro maculada, glabra a pilosa; gluma II, 9-10 mm compr., (-5)7-9-nervada, lanceolada, aristada, arista 1,0-1,5 mm compr., geralmente com máculas vináceas ou estramíneas, glabrescente a pubérula; lema 10-12 mm compr., 7-9-nervado, oblongo-lanceolado, aristado, arista 4-5 mm, maculado, pubérulo; pálea 5-8 $\mathrm{mm}$ compr., 4-nervada, linear-lanceolado, não maculada, raro maculada, creme, glabra, ápice naviculado e escabérulo; lodículas $0,5-1 \mathrm{~mm}$, linear-lanceoladas a oval-lanceoladas, ciliadas próximo ao ápice; anteras 4-5 mm compr., cremes. Cariopse ca. 5,5 mm compr., lanceolada, castanho-clara, ápice e base agudos.

Material examinado: BRASIL. São Paulo: São Paulo, Parque Estadual das Fontes do Ipiranga, IBt, 1-IX-1976, fl., P.H. Davis \& T. Sendulsky 60426 (UEC); IBt, 21-X-2008, fl., R.T. Shirasuna \& A. Costa 1807 (SP); Cien Tec, 29-VII-2010, veg., R.T. Shirasuna 2860; IBt, 17-XII-1959, fl., Borba s.n. (SP358966); IBt, 10-X-1974, fl., T. Sendulsky 1426 (SP); IBt, 1-XI-1974, fl., T. Sendulsky 1428 (SP); IBt, X-1976, fl., T. Sendulsky 1688 (SP); IBt, 13-IV-1974, fl., T. Sendulsky 1393 (SP); IBt, 5-X-2007, fl., D. Vinha s.n. (SP398161).

Aulonemia aristulata apresenta ampla variação morfológica no padrão, tipo e densidade de indumento nas folhas da bainha, pseudopecíolo, lâmina foliar e dimensão das fímbrias (Viana 2010b). Os espécimes do PEFI apresentam as bainhas dos ramos glabras até finamente estrigosas e maculadas, pseudopecíolo híspido-pubescente na face adaxial e híspido na abaxial, cor castanha, lâmina dos ramos com um tufo de tricomas na base da face abaxial; fímbrias conspícuas com até $16 \mathrm{~mm}$ compr., bases eretas com ápice ondulado, castanho-claras a vináceas.

Está amplamente distribuída nas áreas do IBt e Cien Tec, concentrada nas florestas em estágio sucessional secundário médio.

Após a floração em 2007-2008, ocorreu a morte de todas as populações do PEFI, seguida de alta germinação das cariopses, dando prosseguimento à geração seguinte. Devido a esse evento recente, toda a população encontrada estava em estágio de plântulas, concentradas em grandes áreas próximas à população anterior.

Conhecida como: criciúma, taquari (M. Kuhlmann 188, F.C. Hoehne s.n. SP557).

Nos herbários, há registros das florações dos espécimes do PEFI nos anos de 1959, 1974, 1976, 2007 e 2008, o que sugere um ciclo reprodutivo de 15-16 anos, confirmando a citação de Viana (2010b). Uma floração não registrada por volta de 1989-1990 deve ter ocorrido. Outra floração foi registrada pela primeira autora (R.T. Shirasuna et al. 2850) em uma população jovem no Parque Estadual do Rio Turvo, Rio Turvo, SP, em julho/2010.

No Livro Vermelho das Espécies Vegetais Ameaçadas do Estado de São Paulo (Mamede et al. 2007), está inserida na categoria "vulnerável" pelos seguintes critérios: distribuição geográfica restrita em no máximo três municípios do Estado e ocorrência desconhecida em Unidades de Conservação. No entanto, neste estudo constatou-se que essa espécie ocorre em mais de três municípios do Estado de São Paulo e há registros em várias UCs como PEFI, Parque Estadual do Morro do Diabo, Estação Ecológica Juréia-Itatins, entre outras. Portanto, sugere-se aqui a retirada do nome dessa espécie da categoria "vulnerável", colocando-o em outra que reflita o atual nível de conhecimento sobre o seu estado de conservação.

2. Merostachys Spreng., Syst. Veg. 1: 132, 249. 1824.

Caracteres diagnósticos: ramificação intravaginal, complemento de ramo 3-340 ramos subiguais de disposição apsidada, folha do colmo pseudopeciolada, reflexa, sinflorescência racemosa, pectinada, rara não pectinada, espiciforme, determinada, terminal, espiguetas bissexuadas, basítonas, alternas, aos pares, raro ternada; glumas 2, desiguais, extensão de ráquila presente; antécios férteis 1-3(-5); lema 1; pálea 1 ; antécio apical rudimentar 1 ; estames 3 , estigmas 2 , lodículas 3, cariopse nucoide, hilo linear.

Merostachys ocorre na América Central e na América do Sul (Venezuela, Argentina, Paraguai), sendo o Brasil o centro de diversidade (Sendulsky 1992), e o gênero com maior número de espécies com 53 espécies (Filgueiras \& Santos-Gonçalves 2004). Insuficientemente conhecido, com muitas espécies endêmicas e muitas ainda não descritas pela ciência, Merostachys carece de estudos adequados para as diversas espécies ocorrentes no Brasil.

No PEFI registra-se a ocorrência de nove espécies. 


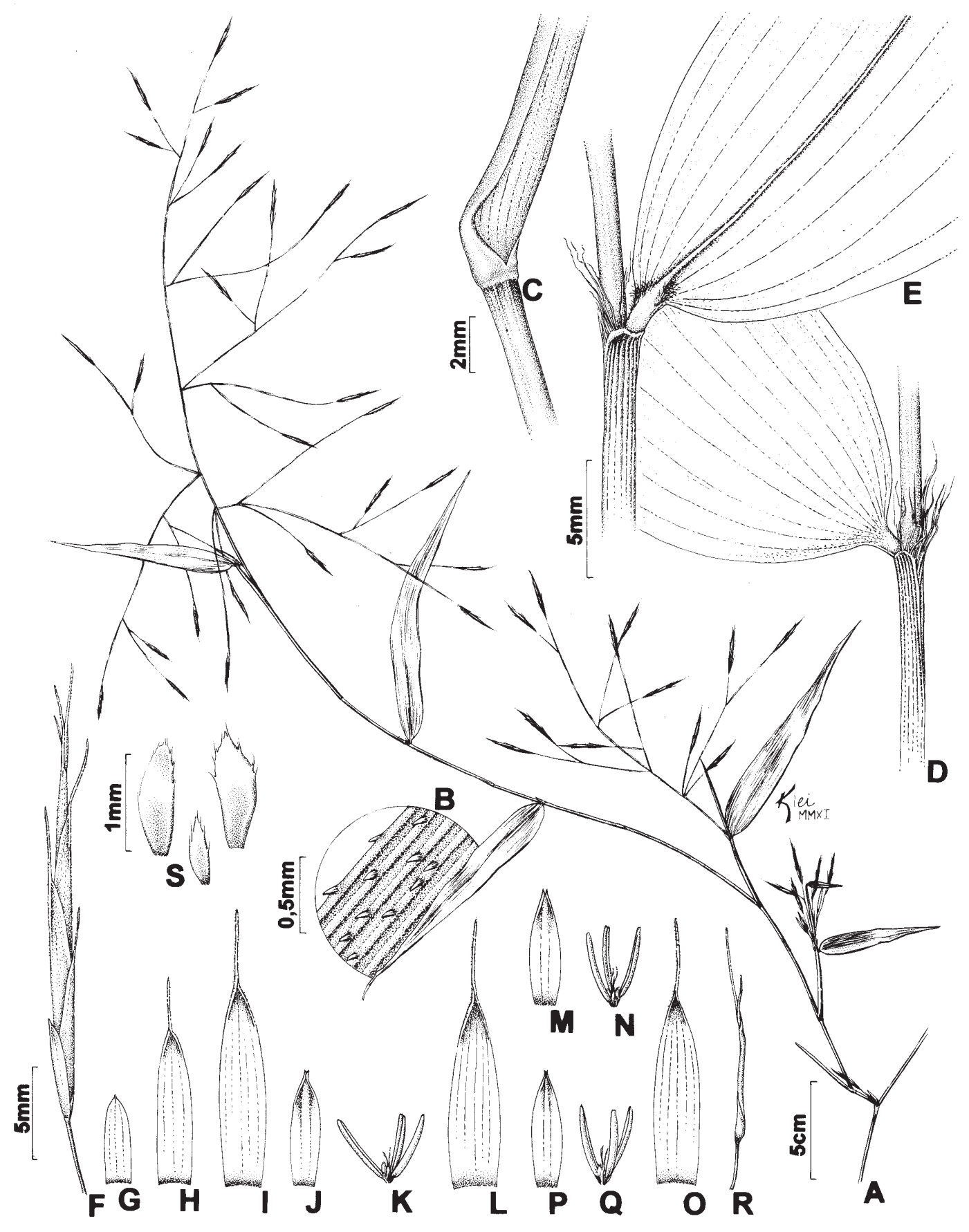

Figura 3. Aulonemia aristulata. A. Ramo fértil. B. Escabrosidade próxima a uma das margens da lâmina. C. Nó da folha do complemento de ramo. D. Fímbrias da folha do complemento de ramo. E. Fímbria da folha do complemento de ramo, com detalhe da base da face abaxial da lâmina. F. Espigueta. G. Gluma I. H. Gluma II. I. Lema do antécio I. J. Pálea do antécio I. K. Flor do antécio I. L. Lema do antécio II. M. Pálea do antécio II. N. Flor do antécio II. O. Lema do antécio III. P. Pálea do antécio III. Q. Flor do antécio III. R. Antécio apical reduzido. S. Lodículas. (D. Vinha S.n. SP398161).

Figure 3. Aulonemia aristulata. A. Fertile branch. B. Scabrous area near the blade margin. C. Node of the foliage leaf. D. Fimbriae of foliage leaf. E. Fimbriae of foliage leaf, with base detail of the blade, abaxial face. F. Spikelet. G. Glume I. H. Glume II. I. Lemma of anthoecium. I J. Palea of anthoecium I. K. Flower of anthoecium I. L. Lemma of the anthoecium II. M. Palea of anthoecium II. N. Flower of anthoecium II. O. Lemma of anthoecium III. P. Palea of anthoecium III. Q. Flower of anthoecium III. R. Apical, reduced anthoecium. S. Lodicules. (D. Vinha s.n. SP398161). 
Chave para identificação das espécies de Merostachys ocorrentes no PEFI

1. Nós dos complementos de ramos dilatados, glabros e negros; fímbrias das folhas do colmo e complementos de ramos ausentes....

1. Nós dos complementos de ramos não dilatados, nem glabros e nem negros; fímbrias das folhas do colmo e complemento de ramos presentes.

2. Linha nodal com faixa de tricomas branco-prateados, muito densos acima e abaixo da linha nodal; entrenós do colmo fortemente maculados com estrias verde-escuras e acinzentados, densamente escabrosos ao longo do colmo; espiguetas com 2-5 antécios férteis ..... 2.5. M. pluriflora

2. Linha nodal sem faixa de tricomas branco-prateados, sem tricomas densos acima e abaixo da linha; entrenós do colmo sem máculas e estrias fortemente marcadas, se presentes, pouco marcadas, fracamente escabrosas, e escabrosidade concentrada na parte distal; espiguetas com apenas 1 antécio fértil

3. Entrenó do colmo pubescente; fímbrias das folhas dos complementos de ramos persistentes, achatadas, unidas na base, margem lisa, brancas 2.1. M. agyronema

3. Entrenó do colmo glabro ou híspido; fímbrias das folhas dos complementos de ramos sem o conjunto de caracteres.

4. Fímbrias das folhas dos complementos de ramos 2-3 mm compr., caducas; sinflorescência não pectinada, i.e., espiguetas inseridas dos dois lados da raquis, raro pectinada

5. Complemento de ramos 100-130 ramos por nó; fímbrias das folhas dos complementos de ramos unidas na base, esbranquiçadas; sinflorescência 8-11 cm compr. 2.2. M. burmanii

5. Complemento de ramos 40-60(-100) ramos por nó; fímbrias das folhas dos complementos de ramos livres, castanho-douradas; sinflorescência 5-6 cm compr. 2.7. M. scandens

4.Fímbrias das folhas dos complementos de ramos 4-25 mm compr., persistentes; sinflorescência pectinada, i.e., espiguetas inseridas somente em um lado da raquis

6. Lâmina das folhas dos complementos de ramos com um tufo de tricomas na base da face abaxial

7. Espiguetas 31-42 por sinflorescência 2.6. M. riedeliana

7. Espiguetas $16-18$ por sinflorescência 2.8. M. skvortzovii

6. Lâmina das folhas dos complementos de ramos sem um tufo de tricomas na base da face abaxial

8. Fímbrias das folhas dos complementos de ramos 3-10 mm compr., livres; 36-40 espiguetas por sinflorescência; espiguetas 11-14 mm compr. 3. M. magellanica

8. Fímbrias das folhas dos complementos de ramos $15-25 \mathrm{~mm}$ compr., unidas na base; 19-25(-33) espiguetas por sinflorescência; espiguetas 17-20 mm compr. 9. M. speciosa

2.1. Merostachys argyronema Lindm., Kongl. Svenska Vetenskapsakad. Handl. 34(6): 22, t.15. 1900. Figura 4

Rizoma paquimorfo, pescoço curto. Colmos 8-10 m alt., eretos na base, arqueados ou escandentes no ápice, 10-20 mm diâm.; entrenós 35-60 cm compr., fistulosos, escabros, pilosos, curtos tricomas esbranquiçados, maculados. Linha nodal castanhoescura, com faixa de tricomas densos acastanhados abaixo da linha nodal. Folhas do colmo: bainha 5-19(-20) × 1,1-3 cm, face abaxial pubescente, castanha, adaxial glabra, castanho-clara, brilhante, margem apical fimbriada, fímbrias ca. $3 \mathrm{~cm}$ compr., esbranquiçadas; lígula externa margem saliente, ciliolada; lígula interna $0,3-0,5 \mathrm{~mm}$ compr., membrano- ciliolada; fímbrias apicais 2,5-30 $\mathrm{mm}$ compr., achatadas, glabras, unidas e eretas, esbranquiçadas; lâmina 1,8-10,5 × 0,3-0,9 cm, híspido-pilosa em ambas as faces, verde-vináceas, margem escabra. Complemento de ramo 10-25 ramos, 20-60 cm compr., 5-9 lâminas por ramo, eretos, ligeiramente geniculados, nós salientes, castanho-escuros. Folhas dos complementos de ramos: bainha glabra, margem pilosa; fímbrias apicais 10-23(-27) mm compr., persistentes, adpressas, achatadas, unidas e eretas na base, ápice viloso, margem lisa, esbranquiçadas; lígula externa margem saliente, ciliolada, glabra; lígula interna 0,1-0,2 mm compr., membranosa, ápice ciliolada; pseudopecíolo 3-5 $\mathrm{mm}$ compr., piloso em ambas as faces, tricomas caducos, verde- 


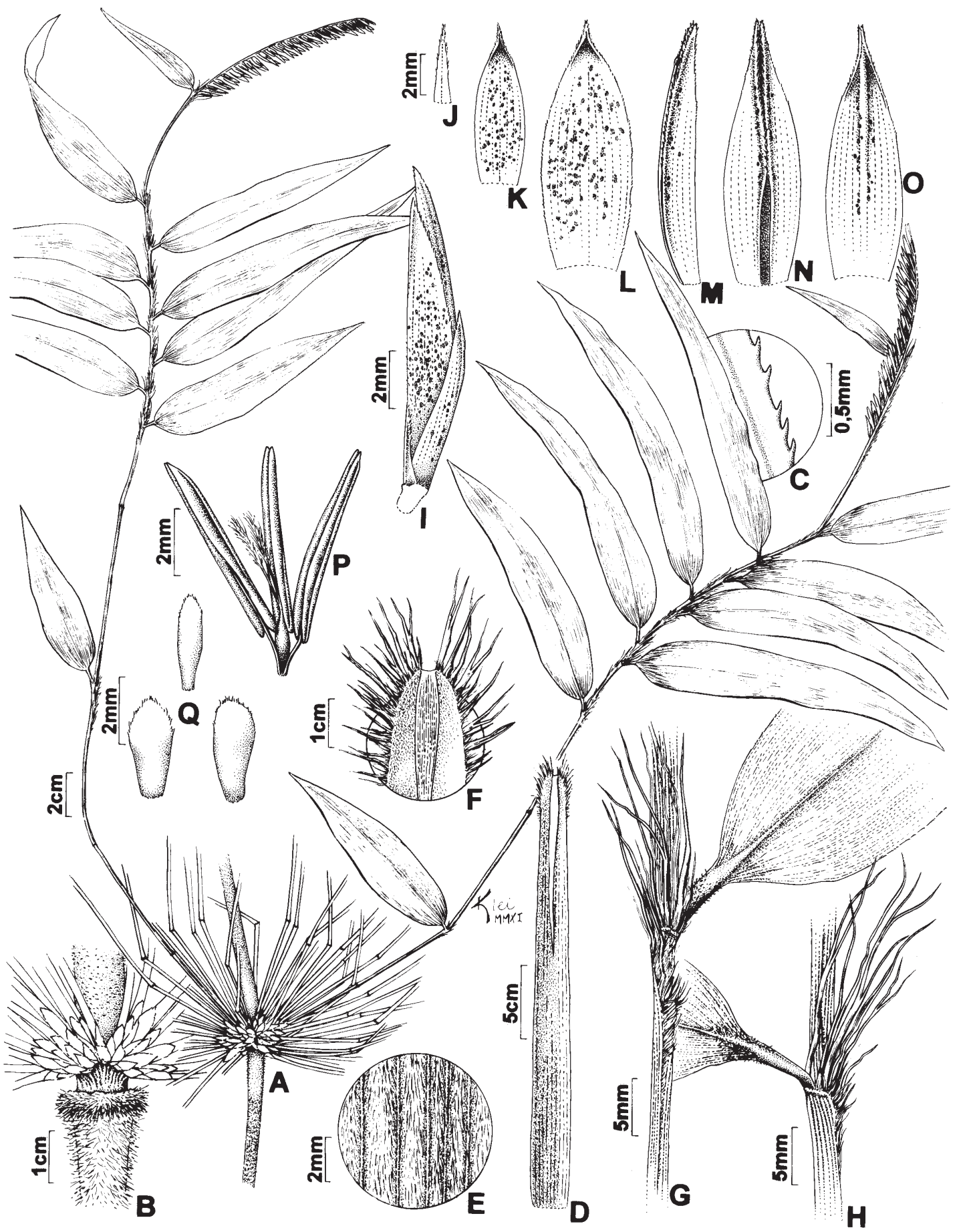

Figura 4. Merostachys argyronema. A. Ramo fértil. B. Nó do colmo com complemento de ramo. C. Margem da lâmina da folha do complemento de ramo. D. Folha do colmo. E. Superfície abaxial da bainha da folha do colmo. F. Ápice da folha do colmo. G. Fímbrias da folha do complemento de ramo com detalhe da base da face adaxial da lâmina. H. Fímbrias da folha do complemento de ramo com detalhe da base da face abaxial da lâmina. I. Espigueta. J. Gluma I. K. Gluma II. L. Lema. M. Pálea. N. Vista dorsal da pálea. O. Vista ventral da pálea. P. Flor. Q. Lodículas. (F. Pinheiro et al. 277- parte fértil; R.T. Shirasuna 2868- parte vegetativa).

Figure 4. Merostachys argyronema. A. Fertile branch. B. Node of the culm with branch complement. C. Blade margin of foliage leaf. D. Culm leaf. E. Abaxial surface of the sheath culm leaf. F. Apex of the culm leaf. G. Fimbriae of foliage leaf, with base detail of the blade, adaxial face. H. Fimbriae of foliage leaf, with detail of the base of the abaxial face of the blade. I. Spikelet. J. Glume I. K. Glume II. L. Lemma. M. Palea. N. Palea, dorsal view. O. Palea, ventral view. P. Flower. Q. Lodicules. (F. Pinheiro et al. 277- fertile organs; R.T. Shirasuna 2868- vegetative organs). 
vináceos; lâmina (9-)14-19 × (1,2-)2,7-3,5 cm, glabra em ambas as faces, exceto na base da face abaxial apresentando um tufo de tricomas e base adaxial 5-7 fileiras de tricomas escabros marginais em um dos lados. Racemo 10-12 cm compr., 40-44 espiguetas por racemo, pectinados, alternos, raque híspida com tricomas esbranquiçados nas margens. Espiguetas (10-)13-15 mm compr., lanceoladas, antécio fértil 1; gluma I (3-)3,5-4 mm compr., 1-nervada, linear-lanceolada, ápice agudo, puberulenta, tricomas concentrados nas margens e nervura apical; gluma II 7-8 mm compr., 7-10-nervada, oblongolanceolada, aristado, arista ca. 1,5 mm compr., maculada, puberulenta, tricomas concentrados nas margens apicais; estípite 1-1,4 mm compr., híspido; lema 9-10 mm compr., 13-15-nervado, lanceolado, internamente maculado, puberulento, tricomas brancos na margem apical, ápice agudo; pálea 12-13 mm compr., 12-nervada, maculada internamente, externamente lisa, puberulenta, tricomas finos nas margens apicais; extensão de ráquila 9-9,5 mm compr., pequeno rudimento apical; lodículas 3-3,2 mm compr., lanceoladas, margem fimbriada; anteras 4-5 mm compr., castanho-claras a alaranjadas. Cariopse não vista.

Material examinado: BRASIL. São PAULo: São Paulo, Parque Estadual das Fontes do Ipiranga, Cien Tec, III-2009, veg., M.T. Grombone-Guaratini s.n. (SP); IBt, 9-IV-1974, veg., T. Sendulsky 1375 (ESA, SP, UEC); IBt, 12-III-2010, veg., R.T. Shirasuna 2791 (SP); Zoológico, 29-VII-2010, veg., R.T. Shirasuna 2866 (SP); Cien Tec, 5-VIII-2010, veg., R.T. Shirasuna 2868 (SP).

Merostachys argyronema é uma das espécies mais facilmente reconhecidas vegetativamente no PEFI por apresentar o entrenó piloso e as fímbrias das folhas dos ramos muito conspícuas, com 10-23 mm compr., achatadas e esbranquiçadas. Pouco se sabe sobre essa espécie devido à escassez de informações bibliográfica e registro de material fértil.

Ocorre na América Central e América do Sul. No Brasil ocorre no domínio da Mata Atlântica, com registro somente na região Sudeste (SP) (Shirasuna 2012b).

Na Grande São Paulo, foi coletada em diversos fragmentos todos fora de UCs, como em Mauá, São Bernardo do Campo e na capital, no bairro de Parelheiros.

Está bem representada no Parque em florestas em estádio sucessional secundário inicial e médio.
Devido à recente floração (2008), todas as populações estavam em estágio de plântula ou ainda muito jovens ca. 2,5 m de altura.

Conhecida como taquara (Filgueiras \& SantosGonçalves, 2006).

A espécie ainda não foi coletada fértil no PEFI. São conhecidas somente duas coletas férteis no Estado de São Paulo, uma na fazenda Castanheiras (2008) e outra em Ubatuba, no litoral paulista (2004). Não há registro sobre seu ciclo de vida. Maiores estudos são necessários para definir esse padrão fenológico.

A espécie não consta do Livro Vermelho das Espécies Vegetais Ameaçadas do Estado de São Paulo (Mamede et al. 2007) e este estudo indica que não está ameaçada de extinção.

2.2. Merostachys burmanii Send., Novon 2(2): 111, f. 1.1992.

Figura 5

Rizoma paquimorfo, pescoço não visto. Colmos 10-15 m alt., eretos na base, arqueados a escandentes no ápice, ca. $40 \mathrm{~mm}$ diâm.; entrenós 38-40 cm compr., fistulosos, maior parte lisa com áreas fortemente escabras, jovens maior parte escabros. Linha nodal escura, com uma camada inferior de tricomas aveludados e esbranquiçados, às vezes com cerosidade. Folhas do colmo: bainha 28-30 × ca. $10 \mathrm{~cm}$, face abaxial com base glabrescente, ápice retrorsamente escabro, castanho-clara; adaxial glabra, castanho-clara, brilhante; lígula externa com margem saliente, ciliolada; lígula interna 1-2 mm compr., membranosa, margem lisa; fímbrias apicais somente no ápice, fímbrias ca. 0,5 mm compr., roliças, glabras, separadas, vilosas e acastanhadas; lâmina 16-17 × 1,8-2,0 cm, glabras em ambas as faces, verde-acastanhadas, margem escabra; Complemento de ramo 100-130 ramos, 50-65 $\mathrm{cm}$ compr., 7-9 lâminas por ramo, nós proeminentes, negros, às vezes castanho-escuros. Folhas dos complementos de ramos: bainha glabra, lisa densamente maculada, margem glabra; fímbrias apicais 2-3 mm compr., caducas, achatadas, unidas na base, eretas com tricomas antrorso-escabras somente na base, ápice viloso e liso, esbranquiçadas a castanho-claras; lígula externa com margem saliente, ciliolada, glabra; lígula interna ca. $1 \mathrm{~mm}$ compr., coriácea, membrano-ciliolada; pseudopecíolo ca. 4 mm compr., glabro, negro; lâmina 15-17 $\times 2-3 \mathrm{~cm}$, glabra em ambas as faces, sem um tufo de tricomas na base da face abaxial, exceto na face adaxial com 2-3 fileiras marginais escabras 


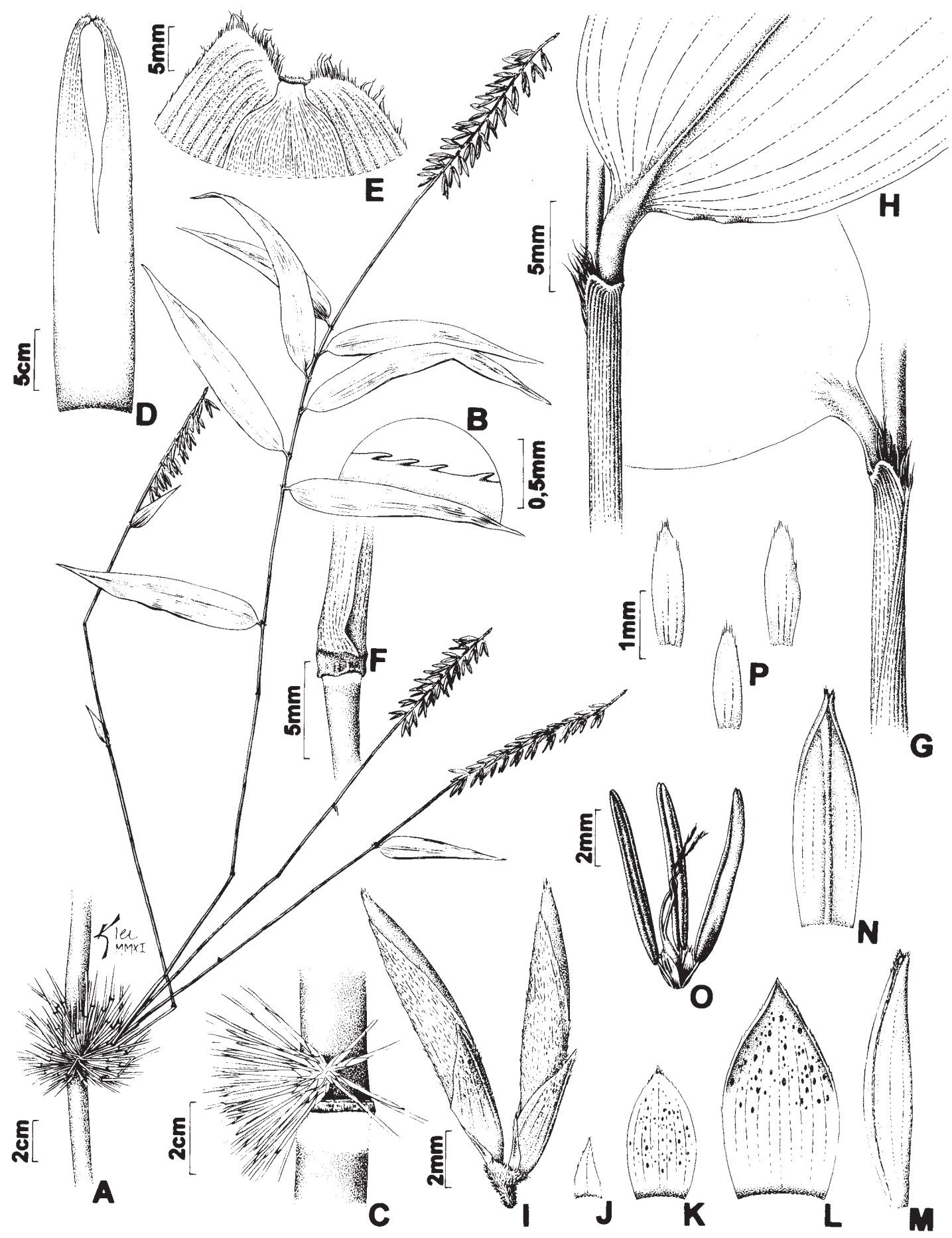

Figura 5. Merostachys burmanii. A. Ramo fértil. B. Margem da lâmina da folha do complemento de ramo. C. Nó do colmo com complemento de ramos. D. Folha do colmo. E. Ápice da folha do colmo. F. Nó do complemento de ramo. G. Fímbrias da folha do complemento de ramo com detalhe da base da face adaxial da lâmina. H. Fímbrias da folha do complemento de ramo com detalhe da base da face abaxial da lâmina. I. Espiguetas. J. Gluma I. K. Gluma II. L. Lema. M. Pálea. N. Vista dorsal da pálea. O. Flor. P. Lodículas. (M. Kuhlmann s.n. SP79757-Holótipo-parte fértil; J.F. Toledo s.n. SP238492-Parátipo-parte vegetativa).

Figure 5. Merostachys burmanii. A. Fertile branch. B. Blade margin of the blade of foliage leaf. C. Node of the culm with branch complement. D. Culm leaf. E. Apex of the culm leaf. F. Node of the branch complement. G. Fimbriae of foliage leaf, with base detail of the blade, adaxial face. H. Fimbriae of foliage leaf, with detail of the base of the abaxial face of the blade. I. Spikelet. J. Glume I. K. Glume II. L. Lemma. M. Palea. N. Palea, dorsal view. O. Flower. P. Lodicules. (M. Kuhlmann s.n. SP79757, fertile organs; J.F. Toledo s.n. SP238492, vegetative organs). 
em um dos lados. Racemo 8-11 cm compr., 40-44 espiguetas por racemo, não pectinado, espiguetas dispostas em ambos os lados da raque, espiguetas aos pares, lateralmente expandidas, frequentemente um dos pares rudimentar ou depauperada, às vezes solitária, raro ternada, maioria deflexa, raque pubescente. Espiguetas $8-11 \mathrm{~mm}$ compr., lanceoladas, antécio fértil 1; gluma I 2-2,5 mm compr., 1-nervada, triangular, ápice acuminado, face abaxial esparsamente hirsuta ao longo do nervo, adaxial ápice pubérulo, tricomas esbranquiçados; gluma II 3,5-5 mm compr., 5-7-nervada, oblongo-lanceolada, não aristada, margem ciliada em direção ao ápice, face adaxial densamente maculada, base abraçando totalmente o lema; estípite ca. $1 \mathrm{~mm}$ compr., híspido; lema 8-10 mm compr., 10-11-nervado, oblongo-lanceolado, levemente curvado, envolvendo totalmente a base da pálea, face adaxial maculado; pálea 8-9 mm compr., 6-nervada, bífida, 2-quilhada, quilha fina e esparsamente denticulada, lanceolada, curvada, estreitamente sulcada abaxialmente; extensão de ráquila ca. $7 \mathrm{~mm}$ compr., tão longo quanto a pálea, finamente pubescente com pequeno rudimento apical; lodículas ca. $2 \mathrm{~mm}$ compr., lanceoladas, finamente cilioladas no ápice; anteras ca. $6 \mathrm{~mm}$ compr., castanho-claras. Cariopse 6-7 mm compr., oblongolanceolada, rostrada, castanho-escura.

Material examinado: BRASIL. São PAulo: São Paulo, Parque Estadual das Fontes do Ipiranga, IBt, 19-I-1944, fl., J.F. Toledo s.n. (SP50362-Parátipo); IBt, Picada Borba, além do lago das Guaricangas à esquerda, 19-V-1959, fl., J.F. Toledo s.n. (SP238492Parátipo); IBt, 23-III-1944, fl., A. Gehrt \& M. Kuhlmann s.n. (SP50462-Parátipo).

Merostachys burmanii assemelha-se a M. scandens por apresentar as sinflorescências não pectinadas, i.e., espiguetas dispostas em ambos os lados da raque, e fímbrias das folhas dos complementos de ramos com 2-3 mm compr. Merostachys burmanii apresenta colmo com 10-15 m alt., 100-130 ramos por nó, 7-9 lâminas por ramo com espiguetas aos pares, $8-11 \mathrm{~mm}$ compr., enquanto que $M$. scandens apresenta colmo com ca. $6 \mathrm{~m}$ alt., 40-60(-100) ramos por nó, 5-6 lâminas por ramo, espigueta solitárias, 10-14 mm compr.

O material tipo desta espécie foi coletado nas matas do PEFI. Sendulsky (1992) citou a ocorrência de espiguetas com 2-3 antécios (Burman \& Soderstrom 525). Esse fenômeno é explicado pela autora como devido ao estresse de um crescimento tardio, enquanto que a maioria já frutificou e morreu, poucas plantas desenvolvem tardiamente novos brotos, que portam as espiguetas anormais, devido ao desenvolvimento contínuo da ráquila.

Ocorre no bioma Mata Atlântica com distribuição nas regiões nordeste (BA) e sudeste (RJ e SP), (400-)600-1.600 m.s.m. (Sendulsky 1992, Shirasuna 2012b).

No PEFI essa espécie não foi localizada durante os trabalhos de campo. Nos rótulos dos materiais tipo não há nenhuma indicação precisa do local de coleta.

Como o tipo de rizoma não é descrito no protólogo (Sendulsky 1992) e a planta não foi encontrada no Parque durante a fase de coletas, não foi possível determinar seu hábito.

Conhecida como taquara (Filgueiras \& SantosGonçalves, 2006).

Foi registrada fértil nos anos de 1915, 1944, 1948, 1959, 1972, 1976 e 1978. Por esses registros parece não haver um padrão de floração muito definido. Mais estudos são necessários para uma definição exata de seu padrão fenológico.

No Livro Vermelho das Espécies Vegetais Ameaçadas do Estado de São Paulo (Mamede et al. 2007) está inserida na categoria "presumivelmente extinta" pelo fato de não haver novos registros nos últimos 50 anos e também pela distribuição restrita no Estado com ocorrência exclusiva em um tipo de formação vegetal. Pelo fato de não ter sido localizada no PEFI durante os trabalhos de campo, mantém-se aqui a mesma avaliação proposta no Livro Vermelho das Espécies Ameaçadas do Estado de São Paulo (Mamede et al. 2007).

2.3. Merostachys magellanica Send., Novon 5(1): 86, f. 6. 1995.

Figura 6

Rizoma paquimorfo, pescoço curto. Colmos 6-13 m alt., eretos na base e pendentes no ápice, 12-14 mm diâm.; entrenós 60-80 cm compr., fistulosos, porção inferior glabros com máculas e faixas esverdeadas, superior com tricomas escabros. Linha nodal castanho-esverdeada com faixa de tricomas acima e abaixo, densos, lanuginosos. Folhas do colmo: bainha $25-30(-36) \times 5-7(-12,8) \mathrm{cm}$, face abaxial com tricomas esbranquiçados, adaxial glabra, brilhante, margem apical fimbriada, fímbrias ca. $5 \mathrm{~mm}$ compr., castanho-douradas; lígula externa com margem saliente, híspida; lígula interna 0,5-0,9 mm compr., membrano-ciliolada; fímbrias apicais 5-6 $\mathrm{mm}$ compr., 


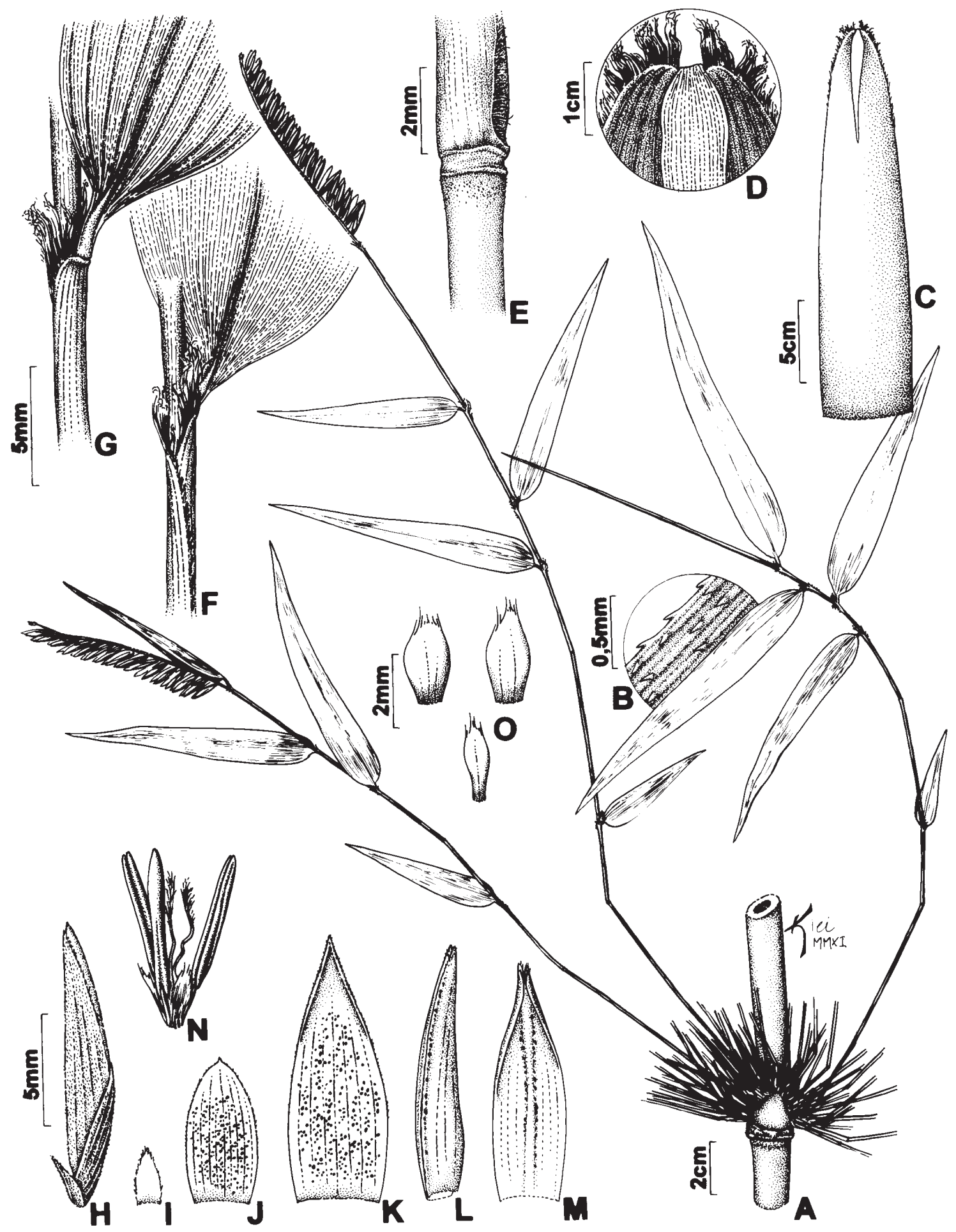

Figura 6. Merostachys magellanica. A. Ramo fértil. B. Margem da lâmina da folha do complemento de ramo. C. Folha do colmo. D. Ápice da folha do colmo. E. Nó do complemento de ramo. F. Fímbrias da folha do complemento de ramo com detalhe da base da face adaxial da lâmina. G. Fímbrias da folha do complemento de ramo com detalhe da base da face abaxial da lâmina. H. Espigueta. I. Gluma I. J. Gluma II. K. Lema. L. Pálea. M. Vista da face dorsal da pálea. N. Flor. O. Lodículas. (F. Barros 2024).

Figure 6. Merostachys magellanica. A. Fertile branch. B. Margin detail of the margin of the blade of foliage leaf. C. Culm leaf. D. Apex of the culm leaf. E. Node of the branch complement. F. Fimbriae of foliage leaf, with base detail of the blade, adaxial face of the blade. G. Fimbriae of foliage leaf, with base detail of the blade, abaxial face of the blade. H. Spikelet. I. Glume I. J. Glume II. K. Lemma. L. Palea. M. Palea, dorsal surface view. N. Flower. O. Lodicules. (F. Barros 2024). 
livres, onduladas e castanho-douradas no ápice, base eretas e esbranquiçadas; lâmina 5-12 × 0,9-1,8 cm, face adaxial híspida, abaxial glabra, margem escabra. Complemento de ramo 12-130 ramos, 15-65 cm compr., 4-7 lâminas por ramo, eretos, ligeiramente geniculados; nós salientes, glabros, castanho-escuros. Folhas dos complementos de ramos: bainha glabra, estriada, margem lisa a pouco ciliolada; fímbrias apicais 3-10 mm compr., persistentes, cilíndrico-achatadas, livres, base eretas e antrorso-escabras, ápice crespo e liso, castanhodouradas; lígula externa com pequena margem saliente, ciliolada; lígula interna $0,2-0,5 \mathrm{~mm}$ compr., membrano-ciliolada; pseudopecíolo 4-5 mm compr., ambas as faces glabras a esparsamente híspidas, verde-vináceos; lâmina $8-17 \times 1,5-2 \mathrm{~cm}$, glabras a subglabras em ambas as faces, sem um tufo de tricomas na base da face abaxial, exceto em uma das margens, adaxial, basal com 2-8 fileiras de tricomas escabros, margem escabra. Racemo 6-18 cm compr., aberto com as espiguetas expandidas, 36-40 espiguetas por racemo, pectinadas, alternas. Espiguetas 11-14 mm compr., lanceoladas, estrigosas, antécio fértil 1; gluma I 3-3,5 mm compr., 1-nervada, triangular, maculada, curtamente estrigosa, vinácea; gluma II 5,5-7,5 mm compr., 9-nervada, lanceolada, maculada, curtamente estrigosa; estípite ca. 2,5 mm compr., finamente estrigoso, tricomas esbranquiçados; lema 10-11,5 mm compr., 14-15-nervado, oblongolanceolado, maculado, finamente estrigoso, margem ciliada; pálea 10,5-12,5 mm compr., menor que o lema, 8-12-nervada, maculada, curvada, 2-quilhada, o dorso das quilhas branco, formando duas linhas brancas longitudinais e paralelas, curtamente ciliadas; extensão de ráquila $10-11 \mathrm{~mm}$ compr., pequeno rudimento apical; lodículas ca. 3,3 $\mathrm{mm}$ compr., finamente ciliolada no ápice com 2-3 nervuras fracas; anteras ca. $9 \mathrm{~mm}$ compr., castanho-claras. Cariopse 6-7 mm compr., rostrada, brilhante, castanho-clara.

Material examinado: BRASIL. São PAULO: São Paulo, Parque Estadual das Fontes do Ipiranga, IBt, 4-II-2009, veg., M.T. Grombone-Guaratini, s.n. (SP412132); IBt, 18-II-2009, veg., R.T. Shirasuna 2168 (SP).

Merostachys magellanica assemelha-se a M. burmanii por apresentar colmos de 13-15 m altura, até 130 ramos por nó, ca. 40 espiguetas por sinflorescência, espiguetas 11-14 mm compr. Porém, difere por M. magellanica apresentar sinflorescências pectinadas e $M$. burmanii apresentar sinflorescência não pectinada, i.e., com espiguetas dispostas em ambos os lados da raque. Segundo Sendulsky (1995), essa espécie é caracterizada pela presença de duas linhas longitudinais brancas formadas pelas quilhas das páleas e por possuir inflorescências congestas. Quando maduras, as sinflorescências são duas vezes tão longas quanto largas, cariopses castanho-claras dorsiventralmente assimétricas (Sendulsky 1995).

Ocorre no bioma Mata Atlântica conhecida somente da região sudeste (SP, RJ) a ca. 700 m.s.m. ocorrendo em solos pobres (Sendulsky 1995, Shirasuna 2012b).

No PEFI foi coletada em apenas dois pontos. Está restrita a apenas uma pequena população em um fragmento de floresta em estádio médio de regeneração na área do IBt.

Conhecida como taquara (Filgueiras \& SantosGonçalves 2006).

Foi registrada fértil nos anos de 1891, 1921, 1922 , 1944, 1956, 1987, 1988 e 1990, nenhuma coleta no Parque. Os dados disponíveis sugerem um ciclo de vida de 30-34 anos (Sendulsky 1995). Porém, mais estudos são necessários para se averiguar o exato padrão fenológico da espécie e a possível existência de florescimento esporádico.

A espécie não consta do Livro Vermelho das Espécies Vegetais Ameaçadas do Estado de São Paulo (Mamede et al. 2007), e essa avaliação é confirmada no presente estudo.

2.4. Merostachys neesii Rupr., Bambuseae: 37, t. 10, f. 31.1839.

Figura 7

Rizoma paquimorfo, pescoço curto. Colmos 10-20 m alt., eretos na base, pendentes a escandentes no ápice, 10-35 mm diâm.; entrenós 24-74 cm compr., fistulosos, glabros, verde-escuros com máculas verdeclaras. Linha nodal castanho-escura a acinzentada, glabra. Folhas do colmo: bainha $24-41 \times 10,9-15,5 \mathrm{~cm}$, glabra em ambas as faces, abaxial castanha a vinácea, opaca, adaxial castanho-brilhante; lígula externa margem saliente, glabra; lígula interna ca. $5 \mathrm{~mm}$ compr., membrano-ciliolada; fímbrias apicais nulas; lâmina 9,4-12,5 × 0,5-1,2 cm, glabra em ambas as faces, margem lisa a obscuramente escabra. Complemento de ramo $11-50$ ramos, $28-95 \mathrm{~cm}$ compr., 4-10 lâminas por ramo, eretos, geniculados, nós 3-4 mm, dilatados, glabros, negros. Folhas dos complementos de ramos: bainha glabra, transverso rugulosa ou papilosa entre as nervuras; fímbrias 


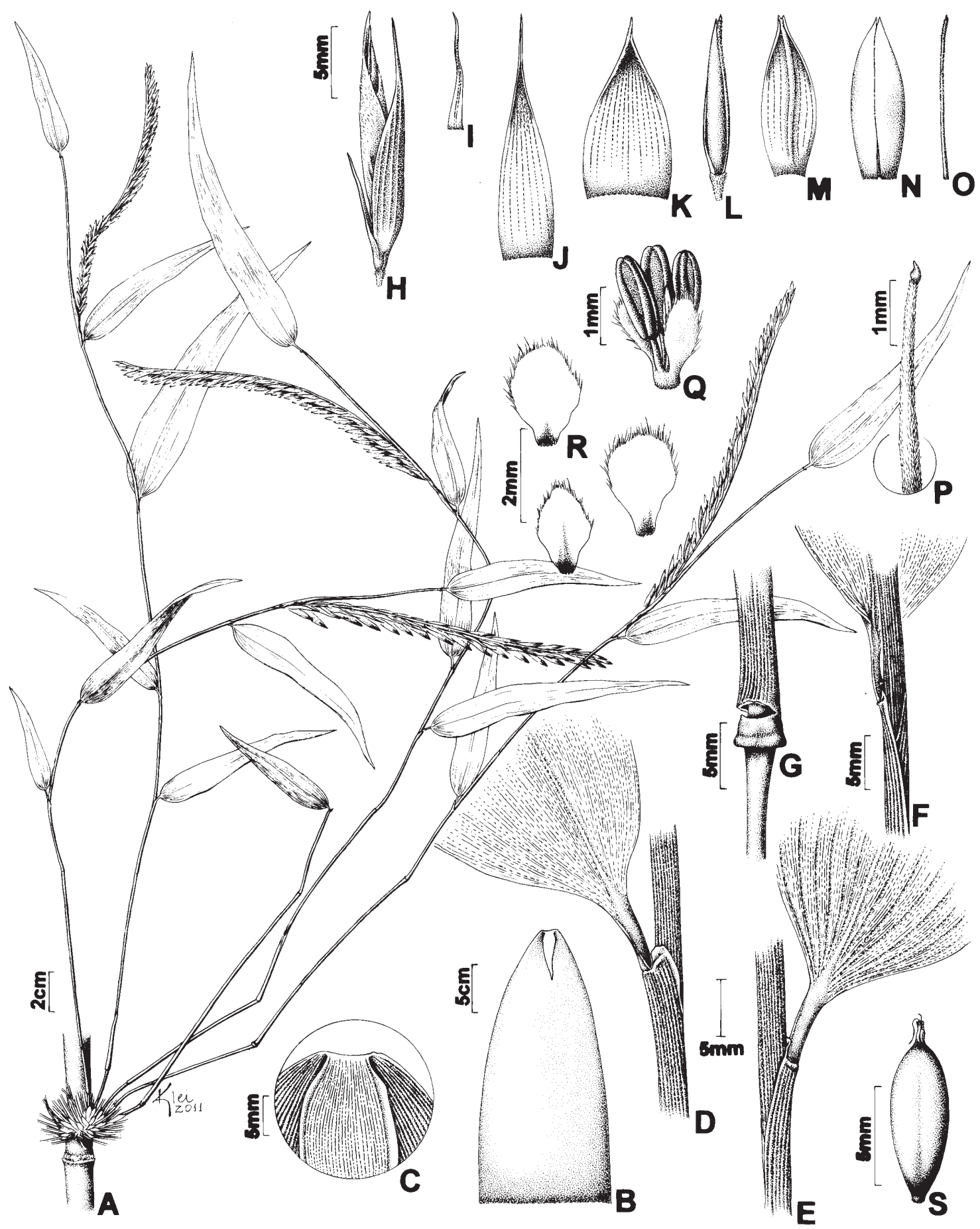

Figura 7. Merostachys neesii. A. Ramo fértil. B. Folha do colmo. C. Detalhe do ápice da folha do colmo. D. Detalhe do ápice da bainha e da base da face adaxial da lâmina do complemento de ramo. E. Detalhe do ápice da bainha e da base da face abaxial da lâmina do complemento de ramo. F. Detalhe da margem da bainha do complemento de ramo. G. Nó do complemento de ramo. H. Espigueta. I. Gluma I. J. Gluma II. K. Lema. L. Pálea. M. Vista ventral da pálea. N. Vista dorsal da pálea. O-P. Extensão de ráquila e rudimento apical. Q. Flor. R. Lodículas. S. Cariopse. (R.T. Shirasuna 2881).

Figure 7. Merostachys neesii. A. Fertile branch. B. Culm leaf. C. Apex detail of the apex of the culm leaf. D. Detail of sheath apex and base of the base of the adaxial side of the foliage leaf. E. Detail of sheath apex and base of the foliage leaf abaxial side. F. Detail of the sheath margin of the sheath of the foliage leaf. G. Node of the branch complement. H. Spikelet. I. Glume I. J. Glume II. K. Lemma. L. Palea. M. Palea, ventral view. N. Palea, dorsal view. O-P. Rachilla extension and apical rudiment. Q. Flower. R. Lodicules. S. Caryopsis. (R.T. Shirasuna 2881). 
apicais nulas; lígula externa miudamente sulcada, glabra; lígula interna 0,2-1,5 mm compr.; membranosa, arredondada; pseudopecíolo 3-6(-8) mm compr., glabro em ambas as faces, castanho-escuro a negro; lâmina 8,8-27 × 1,8-4,5 cm, glabra em ambas as faces, sem um tufo de tricomas na base da face abaxial, base assimétrica, arredondada, ápice acuminado, margem escabra. Racemo 12-20,5(-32,5) cm compr., 13-48(-60) espiguetas por racemo, pectinadas, alternas, raque híspida com tricomas esbranquiçados. Espiguetas 17-21 mm compr., oblongo-lanceoladas, híspido-pilosas, antécio fértil 1; gluma I, 5-8,5 mm compr., 1-nervada, estreitamente lanceolada, acuminada, híspida; gluma II, 15-19(-21) mm, 7-9-nervada, lanceolada, acuminado-aristulada, arista 1-2 mm compr., tricomas esparsos muito curtos; estípite (1-)2-4 mm compr., híspido; lema 12,5-18 mm compr., 17-nervado, oblongo-lanceolado, agudo, híspido, tricomas dourados a enegrescidos, mais densos na margem em direção ao ápice; pálea 12,8-16 mm compr., 10-14-nervada, lanceolada, glabra, naviculada, 2-quilhada, quilhas finamente cilioladas, ápice bifurcado; extensão de ráquila 10-12 mm compr. com pequeno rudimento apical; lodículas 2-2,1 mm compr., oblongas, finamente cilioladas nas margens; anteras ca. $18 \mathrm{~mm}$ compr., castanho-claras. Cariopse ca. $1 \mathrm{~cm}$ compr., ovallanceolada, acastanhada.

Material examinado: BRASIL. São Paulo: São Paulo, Parque Estadual das Fontes do Ipiranga, IBt, 30-VI-1980, fl., S.A.C. Chiea et al. 121 (SP); IBt, 24-I-1949, fl., Hoehne W. Hoehne 2967 (SPF); IBt, 6-IV-1948, fl., M. Kuhlmann 15 (SP); IBt, 16-III-1948, fl., M. Kuhlmann \& E. Kuhn s.n. (SP 367915); IBt, 16-III-1948, fl., Kuhlmann s.n. (SP367917); IBt, 20-I-1949, fl., M. Kuhlmann 3152 (SP); IBt, 10-III-1948, fl., M. Kuhlmann \& J.F. Toledo 3149 (SP); IBt, 20-I-1949, fl., M. Kuhlmann 3154 (SP); IBt, XII-1915, fl., H. Luederwaldt s.n. (SP22354); IBt, 14-IX-1999, veg., L.S. Sarahyba \& D.M.S. Gomes 1033 (PMSP, SP); IBt, 14-IX-1999, veg., L.S. Sarahyba et al. 1035 (SP); IBt, VII-1980, fl., T. Sendulsky s.n. (SP236261); IBt, 18-I-1980, fl., T. Sendulsky s.n. (SP107884); IBt, 14-XII-2009, veg., R.T. Shirasuna 2693 (SP); IBt, 23³8'3,13"S, 46 37'28,9" W, 774 m, 8-II-2010, veg., R.T. Shirasuna 2759 (SP); Cien Tec, 2339'27,1" S, 46³7'25,5"W, 802 m, 29-VII-2010, veg., R.T. Shirasuna 2864 (SP); Cien Tec, 2339'14,7'S, 46³7'25,3"W, 797 m, 26-VIII-2010, fl., R.T. Shirasuna 2881 (SP); IBt, 17-I-1980, fl., T.S. Silva s.n. (SP169275).
Merostachys neesii é facilmente reconhecida por ser a única espécie do PEFI sem fímbrias tanto nas folhas do colmo quanto nas folhas dos ramos e pelos nós dos complementos de ramos dilatados e negros.

Ocorre no bioma Mata Atlântica com distribuição conhecida nas regiões nordeste (BA) e sudeste (RJ, SP) (Shirasuna 2012b). Na Grande São Paulo, foi coletado no município de São Bernardo do Campo e na capital, no bairro de Parelheiros. Todas as coletas foram feitas em fragmentos florestais fora de UCs (Filgueiras \& Shirasuna 2009). Uma pequena população desenvolve-se nas florestas da Estação Biológica do Alto da Serra de Paranapiacaba.

No PEFI foi coletada em 52 pontos. É a espécie do gênero Merostachys mais amplamente distribuída no Parque. A maioria das populações encontra-se em floresta em estádio secundário inicial e secundário médio e algumas em estádio secundário tardio.

Conhecida como taquara (Filgueiras \& SantosGonçalves 2006, Kuhlmann 15).

Foi registrada fértil nos anos de 1915, 1948, 1949, 1980, 1985, 2010 e 2011. Estes dados sugerem um ciclo de 30-33 anos.

Foram encontrados alguns colmos férteis de uma única touceira em 2010 na área do Cien Tec e uma touceira fértil em 2011 no IBt, caracterizando o início do florescimento em massa. Em 2012 quase todos os colmos encontrados no parque foram vistos férteis. Algumas populações da Reserva Florestal do Morro Grande (Cotia, SP) e do bairro de Parelheiros (Capital, SP) foram também avistadas férteis.

No Livro Vermelho das Espécies Vegetais Ameaçadas do Estado de São Paulo (Mamede et al. 2007) está inserida na categoria "presumivelmente extinta", pela ausência de novos registros nos últimos 50 anos. Como $M$. neesii foi encontrada atualmente em diversas localidades inclusive em UCs e em diversos Estados, sugere-se a retirada do nome desta espécie da categoria "presumivelmente extinta", colocando-a na "não ameaçada", que reflete melhor o atual nível de conhecimento sobre o estado conservacionista da espécie (Filgueiras \& Shirasuna 2009).

2.5. Merostachys pluriflora Munro ex E.G. Camus, Bambusees 1: 77. 1913. Figura 8

Rizoma paquimorfo, pescoço curto. Colmos 7-12 $\mathrm{m}$ alt., eretos na base, pendentes a escandentes no ápice, 5-9 mm diâm.; entrenós 30-87 cm compr., fistulosos, fortemente maculados com estrias 


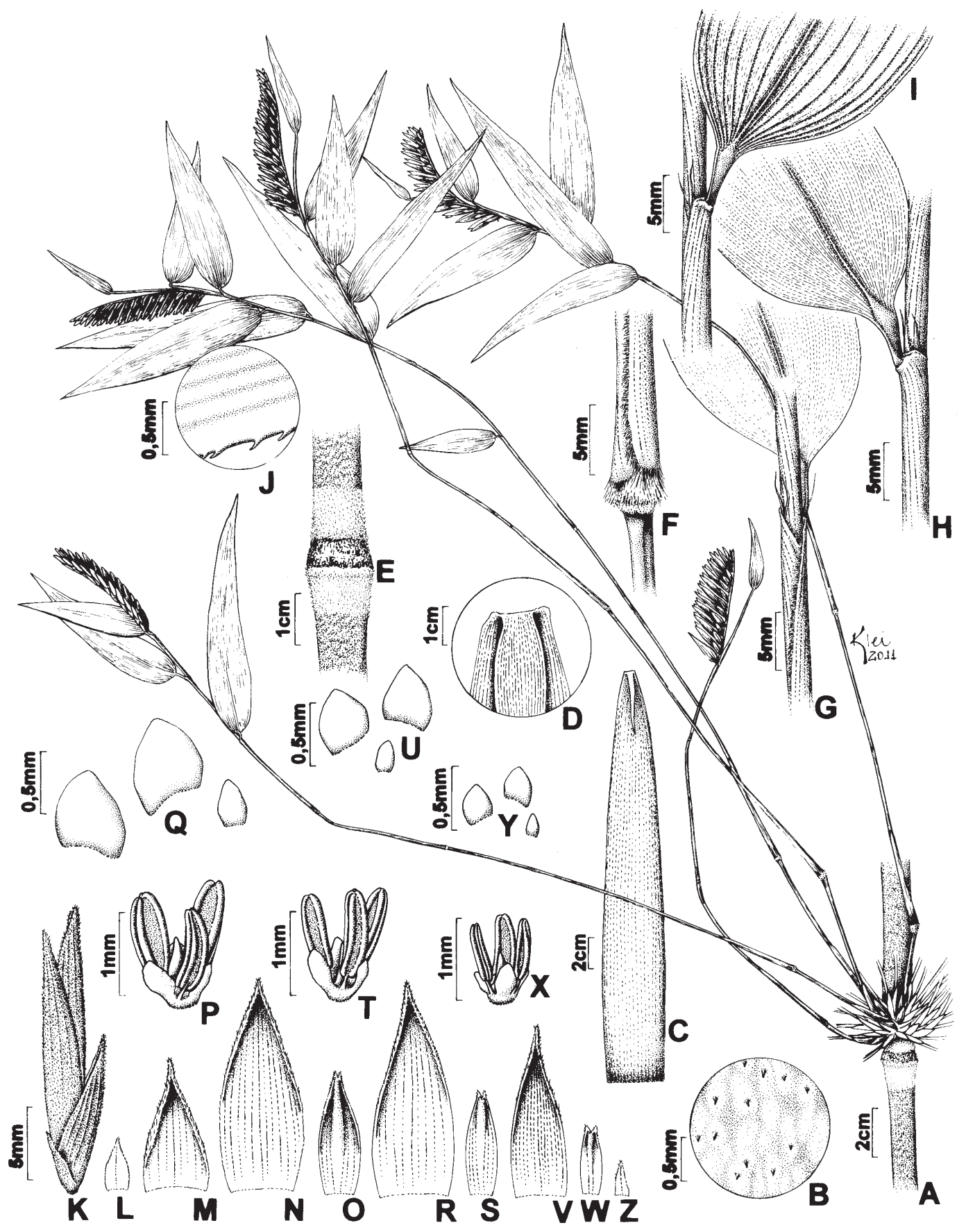

Figura 8. Merostachys pluriflora. A. Ramo fértil. B. Detalhe dos tricomas escabrosos da superfície do colmo. C. Folha do colmo. D. Detalhe do ápice da bainha do colmo. E. Nó do colmo. F. Nó do complemento de ramo. G. Detalhe da margem da bainha da folha do complemento de ramo. H. Fímbrias da folha do complemento de ramo com detalhe da base da face adaxial da lâmina. I. Fímbrias da folha do complemento de ramo com detalhe da base da face abaxial da lâmina. J. Margem da lâmina da folha do complemento de ramo. K. Espigueta com três antécios férteis. L. Gluma I. M. Gluma II. N. Antécio fértil e extensão de ráquila com rudimento apical. O. Lema. P. Pálea biquilhada. Q. Extensão de ráquila com rudimento apical. R. Flor. S. Lodículas. (T. Sendulsky s.n, SP367909-parte fértil, R.T. Shirasuna 2610-parte vegetativa).

Figure 8. Merostachys pluriflora. A. Fertile branch. B. Detail of scabrous trichomes on the culm surface. C. Apex detail of the culm sheath. D. Detail of the apex of the culm sheath. E. Node of the culm. F. Node of the branch complement. G. Detail of the sheath margin of the foliage leaf. H. Fimbriae of foliage leaf, with base detail of the blade, adaxial face. I. Fimbriae of foliage leaf, with base detail of the base of the abaxial face of the blade. J. Blade margin of the foliage leaf. K. Spikelet with three fertile anthoecia. L. Glume I. M. Glume II. N. Fertile anthoecium and rachilla extension with apical rudiment. O. Lemma. P. Palea. Q. Rachilla extension with apical rudiment. R. Flower. S. Lodicules. (T. Sendulsky, s.n., SP367909-fertile organs, R.T. Shirasuna 2610-vegetative organs). 
verde-escuras e acinzentadas, densamente escabros. Linha nodal negra com tricomas esbranquiçadas, faixa de tricomas branco-prateados, muito densos acima e abaixo da linha nodal. Folhas do colmo: bainha $25-42,5 \times 3,5-6,2 \mathrm{~cm}$, face abaxial esparsamente hirsuta a glabra, quando jovem, às vezes, escabra com nervação verde-escura nitidamente marcada, adaxial glabra, margem apical pouco fimbriada, caducas, fímbrias ca. $3 \mathrm{~mm}$ compr.; lígula externa uma margem glabra, saliente; lígula interna 1-2 $\mathrm{mm}$, membranociliolada; lâmina 4,3-15,3 × 0,5-1,2 cm, glabras em ambas as faces, margem escabra; fímbrias apicais nulas ou caducas 4-5 mm compr., quando presentes poucas cerdas. Complemento de ramo 20-84 ramos por nó, 30-80 cm compr., 3-16 lâminas por ramo, eretos raro geniculados, nós uma faixa densa de tricomas esbranquiçados. Folhas dos complementos de ramos: bainha glabra a escabra, margem pilosa; fímbrias apicais 4-8(-13) mm compr., caducas, cerdas 1-4, cilíndrico-achatadas, livres, eretas na base e crespas no ápice, totalmente antrorso-escabras, castanhoclaras com manchas vináceas; lígula externa borda saliente, margem ciliolada; lígula interna ca. $0,5 \mathrm{~mm}$, margem ciliolada; pseudopecíolo 3-7 mm compr., glabro em ambas as faces, verde-vináceo; lâmina 5,2-23,5 × 1,2-2,5 cm, lanceolada, glabra em ambas as faces, sem um tufo de tricomas na base da face abaxial, exceto face adaxial 5-9 fileiras escabras em um dos lados, margem escabra. Racemo 2,5-7 cm compr., 9-26 espiguetas por racemo, pectinada, alternas. Espiguetas 18-23 mm compr., antécios férteis 2-5; gluma I, 2-3(-4) mm compr., 1-nervada, oval-lanceolada, finamente puberulenta; gluma II, 4-11 mm compr., 10-15-nervada, oblongo-lanceolada, puberulenta; estípite nulo; lema 11-14 mm compr., 12-15-nervado, hirsuto com margens apicais ciliados; pálea 12-15 mm compr., 14-20-nervada, 2-quilhada, ápice bifurcado, puberulenta; extensão de ráquila 1,5-5 mm compr., com pequeno rudimento apical; lodículas 1,2-1,5 mm compr., oval-lanceoladas, margem inteira; anteras 6-9 mm compr., acastanhadas. Cariopse não vista.

Material examinado: BRASIL. São Paulo: São Paulo, Parque Estadual das Fontes do Ipiranga, IBt, Jardim Botânico, perto da "área em estudo", 18-III-1960, fl., J.A.F. Borba s.n. (SP153835, SPF); IBt, Perto do abrigo na beira da estrada, defronte a área de estudos, 25-XI-1959, fl., J.A.F. Borba s.n. (MOBOT, PMSP, SP 367908, SPSF); IBt, XI-1991, fl., T. Sendulsky s.n. (SP367909, SPF); IBt, 12-XII-1971, fl., T. Sendulsky s.n. (MOBOT,
PMSP, SP367910, SPF, SPSF); IBt, 13-V-1974, veg., T. Sendulsky 1399 (SP); IBt, 6-IV-1948, veg., M. Kuhlmann \& E. Kuhn s.n. (SP367920); IBt, 30-XI-2005, veg., R.T. Shirasuna \& F. Vitta 127 (SP); IBt, 18-II-2009, veg., R.T. Shirasuna 2172 (SP); Zoológico, 29-VII-2010, veg., R.T. Shirasuna 2865 (SP); IBt, 21-X-2008, veg., R.T. Shirasuna \& A. Costa 1811 (SP); IBt, 22-X-2009, veg., R. T. Shirasuna 2610 (SP); IBt, 4-XI-2009, veg., R.T. Shirasuna 2619 (SP).

Merostachys pluriflora assemelha-se a M. scandens pelo diâmetro do colmo e ápice pendente a escandente. Apresenta o colmo fistuloso com superfície fortemente escabra, enquanto que M. scandens apresenta o colmo meduloso quando jovem e superfície pouco escabrosa. Maiores detalhes estão nos comentários sobre $M$. scandens.

O nome M. pluriflora necessita ser lectotipificado pelo fato da coleção típica ser representado por dois espécimes. Este procedimento será feito posteriormente.

Ocorre no bioma Mata Atlântica com distribuição conhecida nas regiões sudeste (RJ, SP) e sul (SC) (Shirasuna 2012b).

No PEFI foi coletada em 25 pontos, estando bem distribuída. A maioria das populações encontra-se na floresta em estádio secundário médio.

Conhecida como taquara (Filgueiras \& SantosGonçalves 2006).

Foi registrada fértil nos anos de 1958, 1959, 1960, 1971, 1991, 2008 e 2009. Os dados disponíveis não permitem determinar um ciclo definido. São necessários mais dados para uma definição mais precisa do ciclo de floração desta espécie.

A espécie não consta do Livro Vermelho das Espécies Vegetais Ameaçadas do Estado de São Paulo (Mamede et al. 2007), esta avaliação é confirmada no presente estudo.

2.6. Merostachys riedeliana Rupr. ex Döll, Fl. Bras. 2(3): 213. 1880.

Figura 9

Rizoma paquimorfo, pescoço longo $30-100 \mathrm{~cm}$ compr., coberto por catafilos glabros, cremeacastanhados. Colmos 10-15 m alt., eretos na base, arqueados no ápice, 20-40 mm diâm.; entrenós 27-52 cm compr., fistulosos, híspidos com tricomas curtos, caducos, esbranquiçados e cera nos colmos jovens, adultos glabros, máculas longitudinais verdeclaras. Linha nodal escura, com faixa de tricomas esbranquiçados a acinzentados abaixo da linha nodal. 


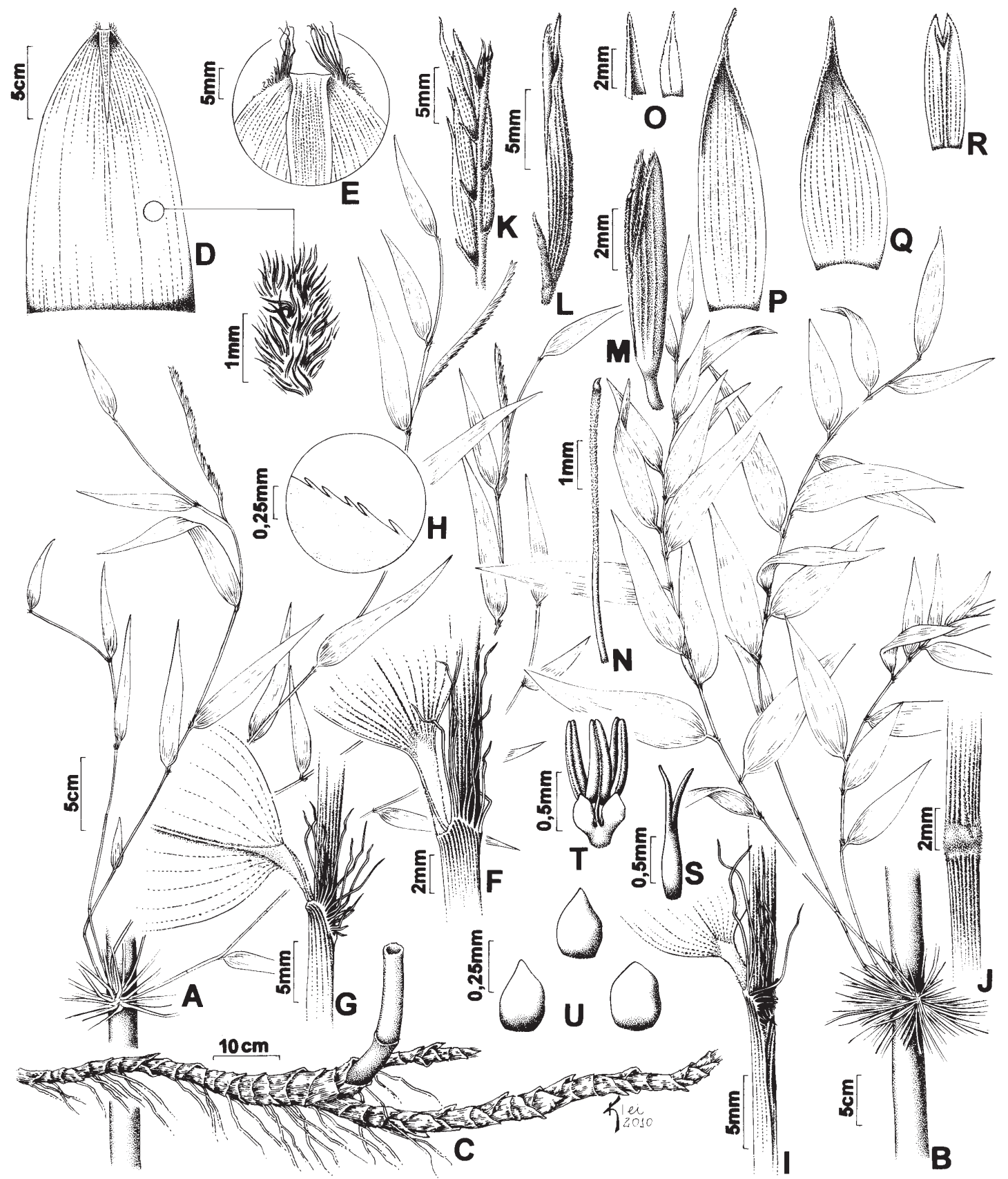

Figura. 9. Merostachys riedeliana. A. Ramo fértil. B. Complemento de ramo. C. Rizoma paquimorfo, pescoço longo revestido por catafilos. D. Folha do colmo com detalhe da superfície abaxial. E. Detalhe do ápice da folha do colmo. F. Fímbrias da folha do complemento de ramo com detalhe da base da face adaxial da lâmina. G. Fímbrias da folha do complemento de ramo com detalhe da base da face abaxial da lâmina. H. Detalhe da margem da lâmina da folha do complemento de ramo. I. Fímbrias da folha do complemento de ramo e pseudopecíolo. J. Nó do complemento de ramo. K. Ápice da sinflorescência. L. Espigueta. M. Pálea com extensão de ráquila e rudimento apical. N. Extensão de ráquila com rudimento apical. O. Distintas vistas da gluma I. P. Gluma II. Q. Lema. R. Pálea aberta biquilhada. S. Flor. T. Gineceu com estígma bífido. U. Lodículas. (parte fértil- T. Sendulsky 271 e vegetativa - R.T. Shirasuna 2831).

Figure 9. Merostachys riedeliana. A. Fertile branch. B. Branch complement. C. Long-necked rhizome covered with cataphylls. D. Culm leaf, detail of the abaxial surface. E. Apex detail of culm leaf. F. Fimbriae of foliage leaf, with base detail of the blade, adaxial face. G. Fimbriae of foliage leaf, with base detail of the blade, abaxial face. H. Detail of the margin foliage leaf. I. Fimbriae of the foliage leaf and pseudopetiole. J. Node of the branch complement. K. Apex of the sinflorescence. L. Spikelet. M. Palea with rachilla extension and apical rudiment. N. Rachilla extension with apical rudiment. O. Distinct views of the glume I. P. Glume II. Q. Lemma. R. Palea. S. Flower. T. Gynoecium with bifurcate stigma. U. Lodicules. (fertile organs- T. Sendulsky 271 and vegetative organs - R.T. Shirasuna 2831). 
Folhas do colmo: bainha 7,8-36,3 × 2-16,5 cm, face abaxial opaca com tricomas lanuginosos, alvo-translúcidos a esbranquiçadas, adaxial glabra, brilhante, margem apical fimbriada, fímbrias 0,5-1,1 mm compr.; lígula externa margem saliente, glabra; lígula interna 1-2 mm compr., membranociliolada; fímbrias apicais 12-21 mm compr., glabras, eretas na base, vilosas no ápice, esbranquiçadas; lâmina 3-12,3 × 0,6-2 cm, linear-lanceolada, abaxial glabra, adaxial híspida, quando jovem uma listra longitudinal, marginal verde-clara em cada lado da lâmina, margem escabra. Complemento de ramo 13-70 ramos por nó, 25-86 cm compr., 4-16 lâminas por ramo, eretos a levemente geniculados, nós pouco salientes, com tricomas curtos, castanho-escuros. Folhas dos complmentos de ramos: bainha glabra, estriada, margem lisa a ligeiramente ciliolada; fimbrias apicais 5-15(-18) mm compr., persistentes, cilíndricoachatadas, livres, ás vezes unidas na base, base eretas, antrorso-escabras, ápice viloso, castanho-claras a esbranquiçadas; lígula externa margem saliente glabra a híspida; lígula interna 0,2-1 mm compr., membranociliolada; pseudopecíolo 3-5(-6) mm compr., ambas as faces glabras ou híspidas, verde-vináceo; lâmina 13,5-21 $\times 2-4,2 \mathrm{~cm}$, glabras em ambas as faces, raro abaxial puberulenta, todas com um tufo de tricomas na base da face abaxial e na face adaxial apresentando 5-9 fileiras escabras marginais em um dos lados. Racemo 8-14,5 cm, (29-)31-42 espiguetas por racemo, pectinadas, alternas, raque híspida. Espiguetas 10-19,4(-21) mm compr., lanceoladas, antécio fértil 1; gluma I, 4-5,5(-7) mm compr., 1-nervada, longo-acuminada a aristada, arista ca. 1,5 mm compr., pubérula com margens apicais cilioladas, pouco maculadas; gluma II, 16-17,9(-19) mm compr., 12-15-nervada, acuminada, puberulenta com margens apicais cilioladas, maculada; estípite ca. $1 \mathrm{~mm}$ compr., puberulento; lema 13-14(-17) mm compr., 12-15-nervado, híspido, margem apical com tricomas esbranquiçados, raro castanho-escuros, totalmente maculado; pálea 6-15(-17) mm compr., 6-10-nervada, 2-quilhada, ápice bifurcada, puberulenta; extensão de ráquila $6-12(-16,5) \mathrm{mm}$ compr., com pequeno rudimento apical; lodículas $0,3-1 \mathrm{~mm}$ compr., oblongolanceoladas, magem inteira; anteras 6-10,5 mm compr., acastanhadas. Cariopse 8-10 mm compr., oblonga.

Material examinado: BRASIL. São PAUlo: São Paulo, Parque Estadual das Fontes do Ipiranga, IBt, 2-V-1949, veg., M. Kuhlmann s.n. (SP367919); IBt, 18-XII-1965, fl., T. Sendulsky 271 (SP); IBt, 12-III-2010, veg., R.T. Shirasuna 2792 (SP); IBt, 16-III-2010, veg., R.T. Shirasuna 2794 (SP); IBt,
16-III-2010, veg., R.T. Shirasuna 2797 (SP); IBt, 18-II-2009, veg., R.T. Shirasuna 2170 (SP); IBt, 22-X-2009, veg., R.T. Shirasuna 2607 (SP); IBt, 13-IV-2010, veg., R.T. Shirasuna 2831 (SP); IBt, 18-II-2009, veg., R.T. Shirasuna 2171 (SP); IBt, 21-X-2008, veg., R.T. Shirasuna \& A. Costa 1810 (SP); IBt, 30-XI-2005, veg., R.T. Shirasuna \& F. Vitta 126 (SP); IBt, 5-V-2010, veg., Shirasuna, R.T. 2832 (SP); IBt, 16-X-1963, veg., Skvortzov, B. 156 (SP); IBt, 22-XI-1963, veg., Skvortzov, B. 168 (US).

Através desse estudo foi possível registrar a ocorrência de um novo padrão de rizoma para o gênero Merostachys: rizoma paquimorfo com pescoçolongo ("long-necked") em $M$. riedeliana. Os rizomas alcançam $1 \mathrm{~m}$ compr., apresentado catafilos que se sobrepõem uns aos outros quando o rizoma cresce na superfície do solo, chegando a formar curvas. Esse novo padrão impõe hábito alastrante e não em touceira como ocorre com a maioria das epécies.

Todos os espécimes examinados seguem o padrão apresentado na descrição da espécie, porém a exsicata L. Danciguer s.n. (SP367904) apresentou a face abaxial das lâminas dos ramos totalmente híspidas, as demais, inclusive todas do PEFI, apresentaram a face abaxial das lâminas dos ramos glabras. A maioria dos espécimes e também todas do PEFI apresentou a margem apical do lema com tricomas esbranquiçados, somente I. Cordeiro et al. 1839, apresentou os tricomas castanho-escuros.

Ocorre no bioma Mata Atlântica com distribuição conhecida na região sudeste (MG, SP) (Shirasuna 2012b). No PEFI foi coletada em 19 pontos concentrando-se nos fragmentos em estádio sucessional secundário médio.

Conhecida como taquara (Filgueiras \& SantosGonçalves 2006, J. Mattos 14557), taquara-poca (Y. Mexia 5499A, 4770).

No PEFI M. riedeliana foi coletada fértil somente no ano de 1965. Registram-se materiais adicionais férteis nos anos de 1930, 1967, 1978, 1995, 1998 e 1999, sugerindo um ciclo de 30-35 anos.

A espécie não consta do Livro Vermelho das Espécies Vegetais Ameaçadas do Estado de São Paulo (Mamede et al. 2007), esta avaliação é confirmada no presente estudo.

2.7. Merostachys scandens Send., Novon 5(1): 92, f. 9. 1995.

Figura 10

Rizoma paquimorfo, pescoço curto. Colmos 5-6 $\mathrm{m}$ alt., eretos a arqueados na base, pendentes ou escandentes no ápice, 10-30 mm diâm.; entrenós 


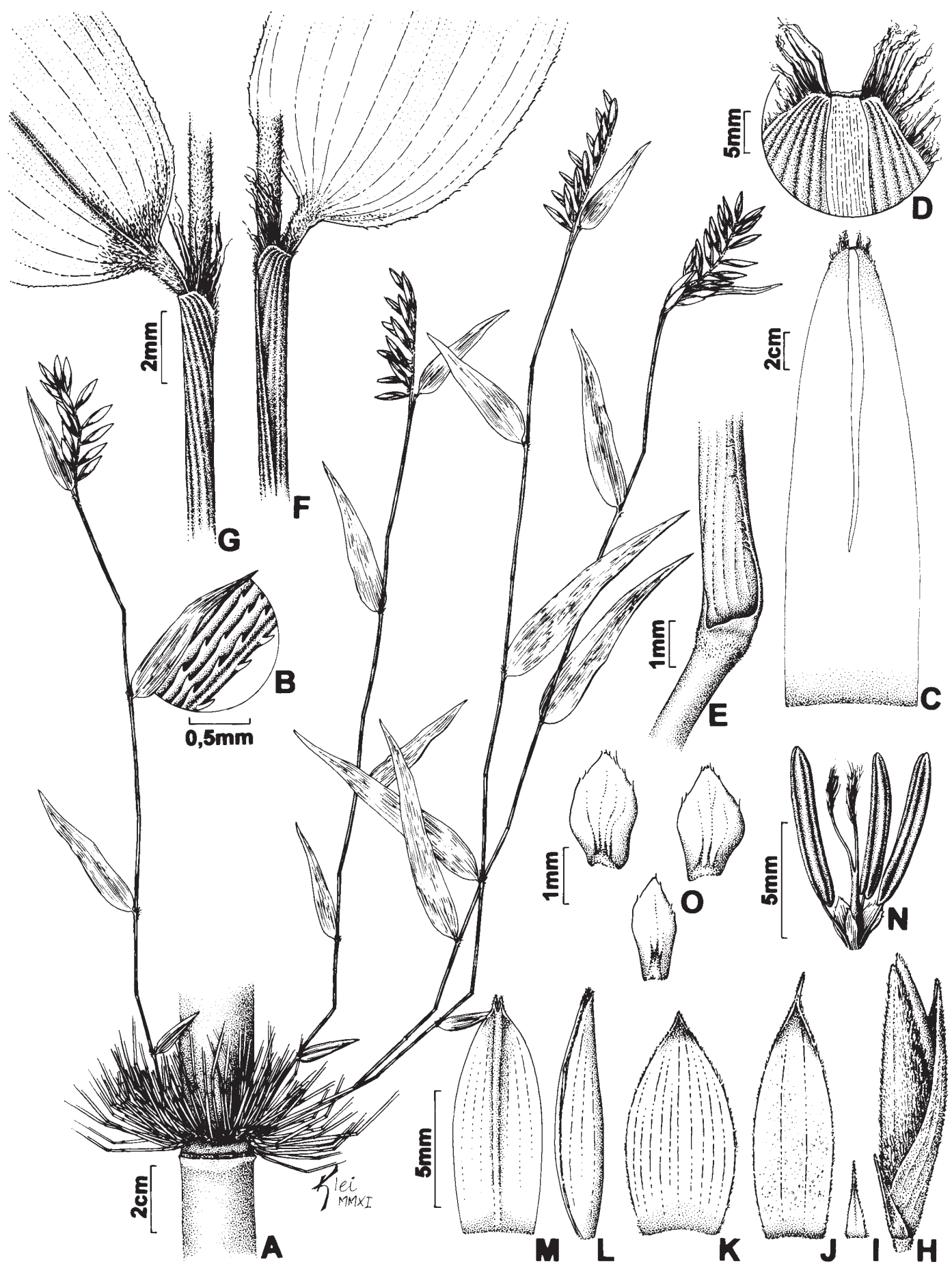

Figura 10. Merostachys scandens. A. Ramo fértil. B. Margem da lâmina da folha do complemento de ramo. C. Folha do colmo. D. Ápice da folha do colmo. E. Nó do complemento de ramo. F. Fímbrias da folha do complemento de ramo com detalhe da base da face adaxial da lâmina. G. Fímbrias da folha do complemento de ramo com detalhe da base da face abaxial da lâmina. H. Espigueta. I. Gluma I. J. Gluma II. K. Lema. L. Pálea e extensão de ráquila com rudimento apical. M. Vista ventral da pálea. N. Flor. O. Lodículas. (O. Handro s.n., SP79756; T. Sendulsky 1320-somente folha do colmo).

Figure 10. Merostachys scandens. A. Fertile branch. B. Blade margin of the blade of foliage leaf. C. Culm leaf. D. Apex of the culm leaf. E. Node of the branch complement. F. Fimbriae of foliage leaf, with base detail of the blade, adaxial face. G. Fimbriae of foliage leaf, with base detail of the blade, abaxial. H. Spikelet. I. Glume I. J. Glume II. K. Lemma. L. Palea and rachilla extension with apical rudiment. M. Palea, ventral view. N. Flower. O. Lodicules. (O. Handro s.n., SP79756; T. Sendulsky 1320-culm leaf). 
51-61 cm compr., medulosos quando jovens e fistulosos quando adultos, finamente escabrosos, verde-escuros acinzentados com listras opacas verde-claras. Linha nodal com tricomas adpressos, retrorsos e esbranquiçados abaixo da linha nodal, híspidos acima da linha. Folhas do colmo: bainha $15-25 \times 3,9-8 \mathrm{~cm}$, superfície adaxial glabra, às vezes, brilhante ou opaca, ápice tesselado, face abaxial híspida, margem apical fimbriada, fímbrias 4-6 mm compr., lígula externa margem saliente, glabra a finamente híspida; lígula externa 1,5-2 mm compr., membrano-ciliolada; fímbrias apicais $1 \mathrm{~cm}$ compr., híspidas, cilíndrico-achatadas, unidas na base, base creme, ápice castanho-dourados; lâmina $8-12 \times 0,4-0,5 \mathrm{~cm}$, face adaxial escabra, abaxial glabra, margem obscuramente escabra;. Complemento de ramo 40-60(-100) ramos por nó, 30-60 cm compr., 5-9 lâminas por ramo, nós vináceo-enegrescidos, não salientes, glabros, abaixo da linha nodal híspido com tricomas esbranquiçados. Folhas dos complmentos de ramos: bainha glabra, zona intercostal finamente transverso rugosa, maculada, margem lisa; fímbrias apicais 3-6(-9) mm compr., caducas, cilíndricoachatadas, livres, base creme, eretas e antrorsoescabras, ápice crespo e liso, castanho-douradas; lígula externa margem saliente, glabra a híspida; lígula interna ca. $0,8 \mathrm{~mm}$ compr., finamente ciliolada; pseudopecíolo 2,5-4 mm compr., levemente puberulento, ceroso; lâmina (3,5-)15-18 × (0,8-)1,5-2,3 cm, adaxialmente glabra, somente com 2-5 fileiras basais escabras, em uma das margens, abaxialmente glabra exceto base finamente estrigosa, sem um tufo de tricomas na base da face abaxial, margem apical estrigosa. Racemo 5-6 cm compr., 17-18 espiguetas arranjadas disticamente, separadas e lateralmente estendidas ao longo da raque, raro pectinada, raque densamente pilosa. Espiguetas 10-14 mm compr., elípticas, antécio fértil 1; gluma I, 4,5-5 mm compr., 1-nervada, lanceolada, atenuada em direção ao ápice, finamente puberulenta; gluma II, 9-10 mm compr., 15-nervada, oval-lanceolada, maculada, ápice escabro, aristulado, arista ca. $1 \mathrm{~mm}$ compr., margem finamente ciliolada; lema 9-12 mm compr., 19-23-nervado, lanceolado, maculado, margem apical densamente ciliado; pálea 9-13 mm compr., 12-nervada, fusiforme, 2-quilhada, quilhas finamente cilioladas, tricomas vináceos, estreitamente sulcada abaxialmente; extensão de ráquila ca. $9 \mathrm{~mm}$ compr. com pequeno rudimento apical; lodículas $2,5 \mathrm{~mm}$ compr., lanceoladas, finamente ciliadas no ápice; anteras 8-9 mm compr., escuras. Cariopse 5,5-6,5 mm compr., oval, rostrada, castanho-acinzentada.
Material examinado: BRASIL. São PaUlo: São Paulo, Parque Estadual das Fontes do Ipiranga, IBt, 8-III-1974, fl., T. Sendulsky 1365 (SP174491-Parátipo); IBt, 6-XII-1973, fl., T. Sendulsky 1320 (SP166799Parátipo); IBt, 17-XII-1973, fl., T. Sendulsky 1323 (SP166803-Parátipo); IBt, 6-XII-1973, fl., T. Sendulsky 1317 (SP166797-Parátipo); IBt, 1-XII-1941, fl., O. Handro s.n. (SP79756-Parátipo).

Merostachys scandens assemelha-se a M. pluriflora pelo diâmetro do colmo e ápice pendente a escandente. M. scandens apresenta o entrenó meduloso quando jovem e fistuloso quando adulto, superfície híspida a finamente escabrosa, verde-escura e nós acastanhados, enquanto M. pluriflora apresenta o entrenó fistuloso tanto jovem quanto adulto, superfície densamente escabra com estrias verde-escuras a acinzentadas e nós enegrescidos. Todos os caracteres são semelhantes entre o material tipo, descrito das matas do Parque e os indivíduos coletados, exceto o entrenó que no protólogo (Sendulsky 1995) é descrito como fistuloso, porém a autora não especifica se o colmo é meduloso quando jovem. Como em um parátipo (Sendulsky 1365) o entrenó mostra-se meduloso nos colmos jovens, optou-se por acrescentar mais este caráter à descrição.

O tipo de rizoma não consta do protólogo, sendo este aqui descrito como paquimorfo com pescoço curto.

O tamanho das lâminas dos ramos e o número de lâminas por ramo na descrição aqui apresentada divergem do protólogo. Isto se deve ao fato de que o material citado no protólogo ter sido coletado em estado fértil e os coletados durante este estudo estar em estado vegetativo. Os materiais vegetativos apresentam folhas maiores e em maior número.

É conhecida somente no bioma Mata Atlântica com distribuição restrita à região sudeste, apenas no Estado de São Paulo (Shirasuna 2012b), exclusiva do PEFI. Foi localizado somente uma pequena população em apenas um ponto próximo a trilha principal do IBt.

Conhecida como taquara (Filgueiras \& SantosGonçalves 2006).

Foi registrada fértil nos anos de 1941, 1972 e 1974, sugerindo um ciclo reprodutivo de 31-33 anos (Sendulsky 1995).

Segundo Sendulsky (1995) M. scandens floriu na mesma época que $M$. skvortzovii no PEFI, por volta de 1973-1974.

No Livro Vermelho das Espécies Vegetais Ameaçadas do Estado de São Paulo (Mamede et al. 
2007) está inserida na categoria "vulnerável", pelos seguintes critérios: distribuição geográfica restrita em no máximo três municípios do Estado e ocorrência desconhecida em Unidades de Conservação. Neste estudo confirmou-se sua ocorrência exclusiva no PEFI, sua localidade típica, onde é rara. Portanto, trata-se de uma espécie "criticamente ameaçada".

2.8. Merostachys skvortzovii Send., Novon 5(1): 94, f. 10. 1995.

Figura 11

Rizoma paquimorfo, pescoço curto. Colmos 4-12 m alt., eretos na base e flexuosos no ápice, 20-30 mm diâm.; entrenós 30-45 cm compr., medulosos quando jovem e fistulosos quando adultos, escabros, com manchas verde-claras bem marcadas. Linha nodal faixa larga de tricomas esbranquiçados acima e abaixo da linha nodal. Folhas do colmo: bainha 15-20 × 5-6 cm, auriculada, face abaxial opaca, escura, estriada, finamente ciliolada na margem, cílios esbranquiçados, adaxial glabra, escura, margem apical pouco fimbriada, fímbrias ca. $2 \mathrm{~mm}$ compr.; lígula externa margem saliente, ciliolada; lígula interna ca. $1 \mathrm{~mm}$ compr., membrano-ciliolada; fímbrias apicais 1-2 mm compr., cilíndricas, livres, antrorso-escabras, com poucos tricomas acastanhados; lâmina 6-10 × ca. $1 \mathrm{~cm}$, híspida em ambas as faces, verde-acastanhada, margem escabra. Complemento de ramo 50-200 ramos por nó, 20-50 cm compr., 5-7 lâminas por ramo, nós pouco salientes, acastanhados, híspidos. Folhas dos complementos de ramos: bainha glabra, estriada; fímbrias apicais 5-12 mm compr., persistentes, cilíndricas, livres, base eretas, antrorsoescabras, ápice crespo, acastanhadas; lígula externa margem saliente, ciliolada; lígula interna 0,8-1 mm compr., membrano-ciliolada; pseudopecíolo 2-3 mm compr., finamente puberulento, esverdeado; lâmina 3-15,5 × 0,6-2,7 cm, abaxialmente glabra a levemente pilosa, com tufo de tricomas na base, face adaxial 3-4 fileiras escabras na base de uma das margens. Racemo 1,5-8,5 cm compr., 16-18 espiguetas por panícula, pectinadas, alternas, raque híspido-piloso, tricomas esbranquiçados. Espiguetas 10-14 mm compr., fusiforme, antécio fértil 1; gluma I, 1,5-2 mm compr., 1-nervada, acuminada, finamente puberulenta; gluma II, 8-13 mm compr., 9-13-nervada, oval-lanceolada, maculada, aristulada, arista ca. $1 \mathrm{~mm}$ compr., finamente puberulenta, ápice escabro; lema 9-13 mm compr., 15-21-nervado, ovallanceolado, maculado, finamente puberulento, margem ciliada; pálea 10-13 mm compr., 13-14-nervada, 2-quilhada, quilhas finamente cilioladas, estreitamente sulcada abaxialmente, glabra, brilhante; extensão de ráquila ca. $8 \mathrm{~mm}$ compr., com pequeno rudimento apical; lodículas ca. 3,2 $\mathrm{mm}$ compr., oblongolanceoladas, margem finamente laciniada; anteras ca. $6 \mathrm{~mm}$ compr., escuras. Cariopse 3-5 mm compr., oval, rostrada, castanho-acinzentada.

Material examinado: BRASIL. São Paulo: São Paulo, Parque Estadual das Fontes do Ipiranga, IBt, 17-XII-1973, fl., T. Sendulsky 1321 (SP169753Parátipo); IBt, 23-XII-1973, fl., T. Sendulsky 1324 (SP166802-Parátipo); IBt, 21-X-1941, fl., A. Gehrt s.n. (SP46009-Parátipo); IBt, 7-II-1974, fl., T. Sendulsky 1341 (SP174478-Parátipo); IBt, 20-X-1973, fl., T. Sendulsky 1315 (SP166798-Parátipo); IBt, 17-XII-1973, fl., T. Sendulsky 1322 (SP166795Parátipo); IBt, 6-XII-1973, fl., T. Sendulsky 1318 (SP166796-Parátipo); IBt, 10-X-1973, fl., T. Sendulsky 1314 (SP166801-Parátipo); IBt, 14-IX-1999, veg., L.S. Sarahyba et al. 1034 (PMSP, SP).

Merostachys skvortzovii assemelha-se a $M$. riedeliana pelo porte robusto ca. $12 \mathrm{~m}$ altura com ápice arqueado, presença de um tufo de tricomas na base da face abaxial das lâminas dos ramos e sinflorescência pectinada. Apresenta 50-200 ramos por nó, 5-7 lâminas por ramo, 16-18 espiguetas por sinflorescência versus 13-70 ramos por nó, 4-16 lâminas por ramo, 31-42 espiguetas por sinflorescência em $M$. riedeliana. Assemelha-se a $M$. scandens por ter os entrenós do colmo medulosos quando jovens e fistulosos quando adultos.

O material tipo desta espécie foi baseado em coletas realizadas no Parque (Sendulsky 1995).

Tem distribuição conhecida no bioma Mata Atlântica nas regiões sudeste (SP) e sul (PR, RS, SC) (Shirasuna 2012b). Esta espécie não foi localizada em nenhuma área do PEFI durante a fase de coletas. Não há nenhuma indicação precisa do local de coleta nos rótulos das exsicatas. Foram encontradas algumas plantas jovens de Merostachys sp. que poderiam pertencer a esta espécie, porém não foi possível confirmar essa hipótese.

Conhecida como taquara (Filgueiras \& SantosGonçalves 2006), taquara-lixa (Liebsch \& Reginato 2009, http://pt.wikipedia.org/wiki/Bambu-taquara).

Foi registrada fértil nos anos de 1941, 1973, 1974, 2004 e 2005, sugerindo um ciclo de vida de 31-33 anos.

Há registros de florescimento massivo em 2004 e subsequente mortalidade em 2005-2007 em diversas 


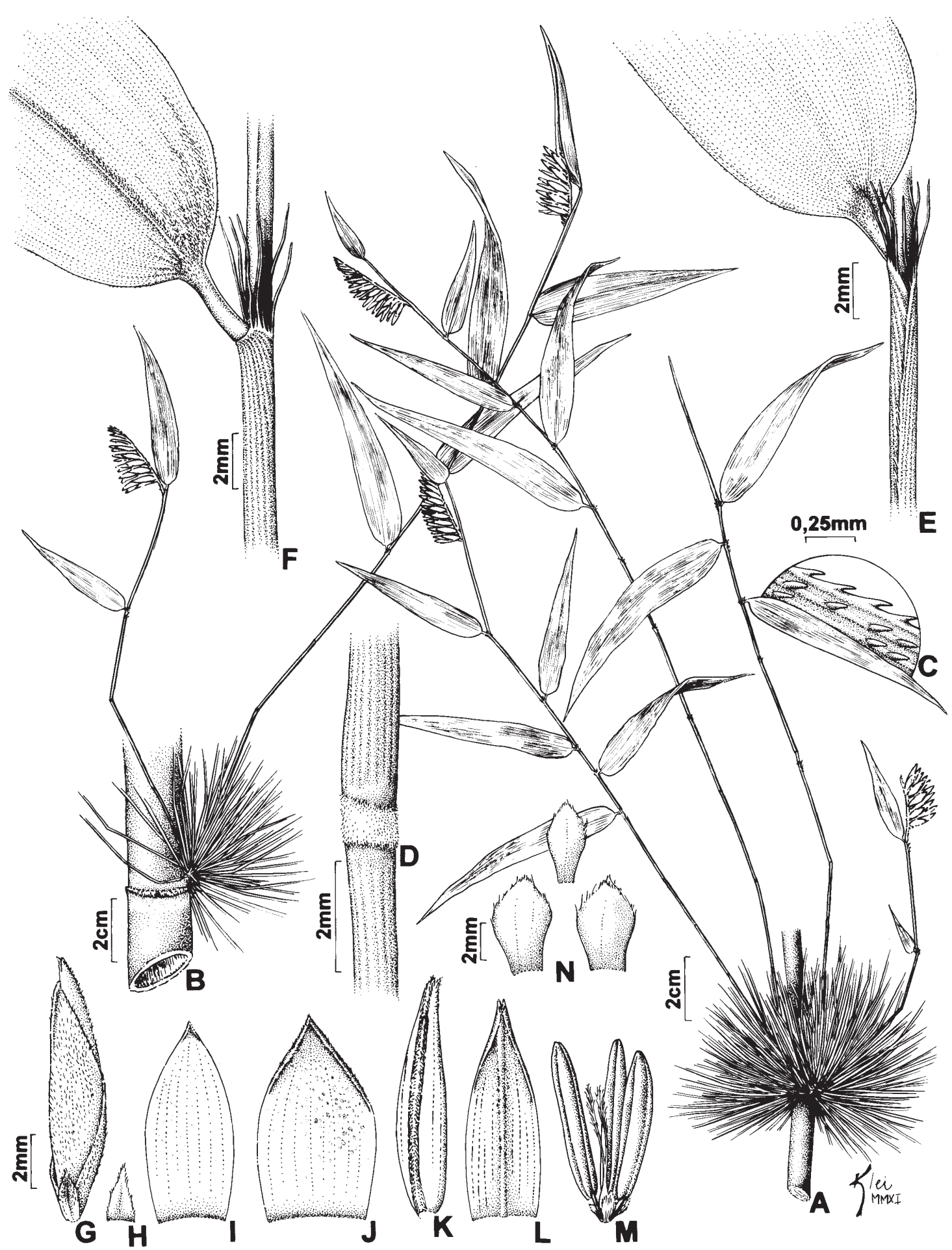

Figura 11. Merostachys skvortzovii. A. Ramo fértil, detalhe do colmo meduloso. B. Ramo fértil, detalhe do colmo fistuloso. C. Margem da lâmina da folha do complemento de ramo. D. Nó do complemento de ramo. E. Fímbrias da folha do complemento de ramo com detalhe da base da face adaxial da lâmina. F. Fímbrias da folha do complemento de ramo com detalhe da base da face abaxial da lâmina. G. Espigueta. H. Gluma I. I. Gluma II. J. Lema. K. Pálea com extensão de ráquila e rudimento apical. L. Vista ventral da pálea. M. Flor. N. Lodículas. (T. Sendulsky 1321, 1322-Parátipos).

Figure 11. Merostachys skvortzovii. A. Fertile branch, detail of the medulose culm. B. Fertile branch, detail of the fistulose culm. C. Blade margin of the blade of foliage leaf. D. Node of the branch complement. E. Fimbriae of foliage leaf, with base detail of the blade, adaxial face. F. Fimbriae of foliage leaf, with base detail of the blade, abaxial face. G. Spikelet. H. Glume I. I. Glume II. J. Lemma. K. Palea with rachilla extension and apical rudiment. L. Palea, ventral view. M. Flower. N. Lodicules. (T. Sendulsky 1321, 1322-Paratypes). 
localidades do Estado do Paraná e norte do Estado de Santa Catarina, confirmando o ciclo fenológico de aproximadamente 31-33 anos (Sendulsky 1995, Schwarzbach et al. 2008).

No Livro Vermelho das Espécies Vegetais Ameaçadas do Estado de São Paulo (Mamede et al. 2007) está inserida na categoria "vulnerável", pelos seguintes critérios: distribuição geográfica restrita em no mínimo três municípios do Estado e ocorrência desconhecida em Unidades de Conservação. Neste trabalho constatou-se que esta espécie ocorre em três municípios do Estado de São Paulo, porém com registros em duas UCs (PEFI e Estação Ecológica de Assis). Portanto, deve ser enquadrada em outra categoria mais adequada ao atual nível de conhecimento sobre a espécie.

2.9. Merostachys speciosa Spreng., Syst. Veg. 2: 249, f. $37 b-n .1825$.

Figura 12

Rizoma paquimorfo, pescoço curto. Colmos 10-15 m alt., eretos na base, escandentes no ápice, 20-30 mm diâm.; entrenós 35-88 cm, cilíndricos, fistulosos, glabros, verde-glauco com pequenas erupções alongadas e acastanhadas na superfície. Linha nodal faixa $0,3-0,7 \mathrm{~cm}$ glabra, acastanhada, exceto na base a ápice com tricomas esbranquiçados. Folhas do colmo: bainha 22-23,7 × 4-13,3 cm, face abaxial glabra, castanho-esverdeada a verde-glauca com cera esbranquiçada nas bainhas jovens, face adaxial castanho-brilhante, lisa, margem apical fimbriada, fímbrias ca. $12 \mathrm{~mm}$ compr., achatadas, unidas na base, ápice crespo, douradas; lígula externa margem saliente, ciliolada; lígula interna 1,5-2 mm compr., membranociliolada; fímbrias apicais 13-20(-25) mm compr., lisas, adpressas, bases eretas, achatadas e unidas, ápices livres, crespas, castanho-claras a douradas; lâmina 7,1-14,7 × 0,6-0,8 cm, glabra em ambas as faces, verdes, margem escabra. Complemento de ramo 13-40 ramos, 50-88 cm compr., 6-16 lâminas por ramo, nós salientes, castanho-escuros a negros, glabros. Folhas dos complementos de ramos: bainha glabra a pilosa com tricomas brancos, margem ciliolada; fímbrias apicais $15-25 \mathrm{~mm}$ compr., douradas a castanho-claras, persistentes, totalmente lisas, bases achatadas e unidas, ápices crespos, prolongando-se 2-4 mm pela margem da bainha; lígula externa borda saliente, glabra com margem irregular; lígula interna 0,3-1 mm compr., membranosa, irregular, margem finamente ciliolada; pseudopecíolo 5-6 mm compr., face adaxial glabro, abaxial glabro, hirsuto próximo à lâmina, castanho-escuro; lâmina 13,5-25 × 3-3,6 cm, ambas as faces glabras, sem um tufo de tricomas na base da face abaxial, exceto na face adaxial, 5-8 fileiras escabras, basais em uma das margens, base assimétrica, aguda, ápice agudo, margem escabra. Racemo 7-15,5 cm, 19-25(-33) espiguetas, pectinadas, alternas. Espiguetas 17-24 mm compr., lanceoladas, estrigosas, tricomas dourados, antécio fértil 1; gluma I, 4-6(-10) mm compr., 5-nervada, lanceolada, acuminado-aristulada a aristada, arista 3-4 mm compr, maculada, híspida, margem superior pilosa, tricomas castanho-dourados; gluma II, 16-18 mm compr., 7-nervada, lanceolada, acuminadoaristulada, arista (1-)3-4 mm compr., maculada, densamente pilosa próximo à margem; estípite 2-3 mm, híspido; lema (16-)19-20 mm compr., 16-18-nervado, oblongo-ovalado, aristado, arista 1,5-4 mm compr., esparsamente pilosa, mais denso na margem apical, tricomas dourados; pálea 19-20 mm compr., 8-nervada, lanceolada, dobrada, sulcada abaxialmente, glabra; extensão de ráquila 16-17,5 mm compr. com pequeno rudimento apical; lodículas ca. $4 \mathrm{~mm}$ compr., lanceoladas, margem fimbriada; anteras 12-14 mm compr., castanhas. Cariopse não vista.

Material examinado: BRASIL. São Paulo: São Paulo, Parque Estadual das Fontes do Ipiranga, IBt, 16-III-2010, veg., R.T. Shirasuna 2796 (SP); IBt, 16-III-2010, veg., R.T. Shirasuna 2798 (SP).

Material adicional: BRASIL. MinAs Gerais: Viçosa, 12-IV-1925, fl., veg. A. Chase 9466 (MOBOT). ParanÁ: Jacarehy, 23-XI-1915, fl., P. Dusén 17348 (MOBOT878197-Parátipo). São Paulo: São Paulo, Campinas, Fazenda Santa Elisa, 28-XI-1962, fl., J. Correa-Gomes Jr. 1268 (SPF, UB).

Merostachys speciosa assemelha-se a M. argyronema principalmente pelo crescimento em touceira, ápice escandente, fímbrias conspícuas das folhas dos ramos 10-25 mm compr. e sinflorescência pectinada. Difere por $M$. speciosa possuir 13-40 ramos por nó, 6-16 lâminas por ramo, fímbrias castanhodouradas, lâminas dos ramos sem um tufo de tricomas na base da face abaxial, espiguetas 17-24 mm compr., enquanto que $M$. argyronema apresenta 10-25 ramos por nó, 5-9 lâminas por ramo, fímbrias esbranquiçadas, lâmina dos ramos com um tufo de tricomas na base da face abaxial e espiguetas 13-15 mm compr. A coleta Dusén 17348 apresenta espigueta com apenas uma gluma e antécio inferior masculino, com pálea. 


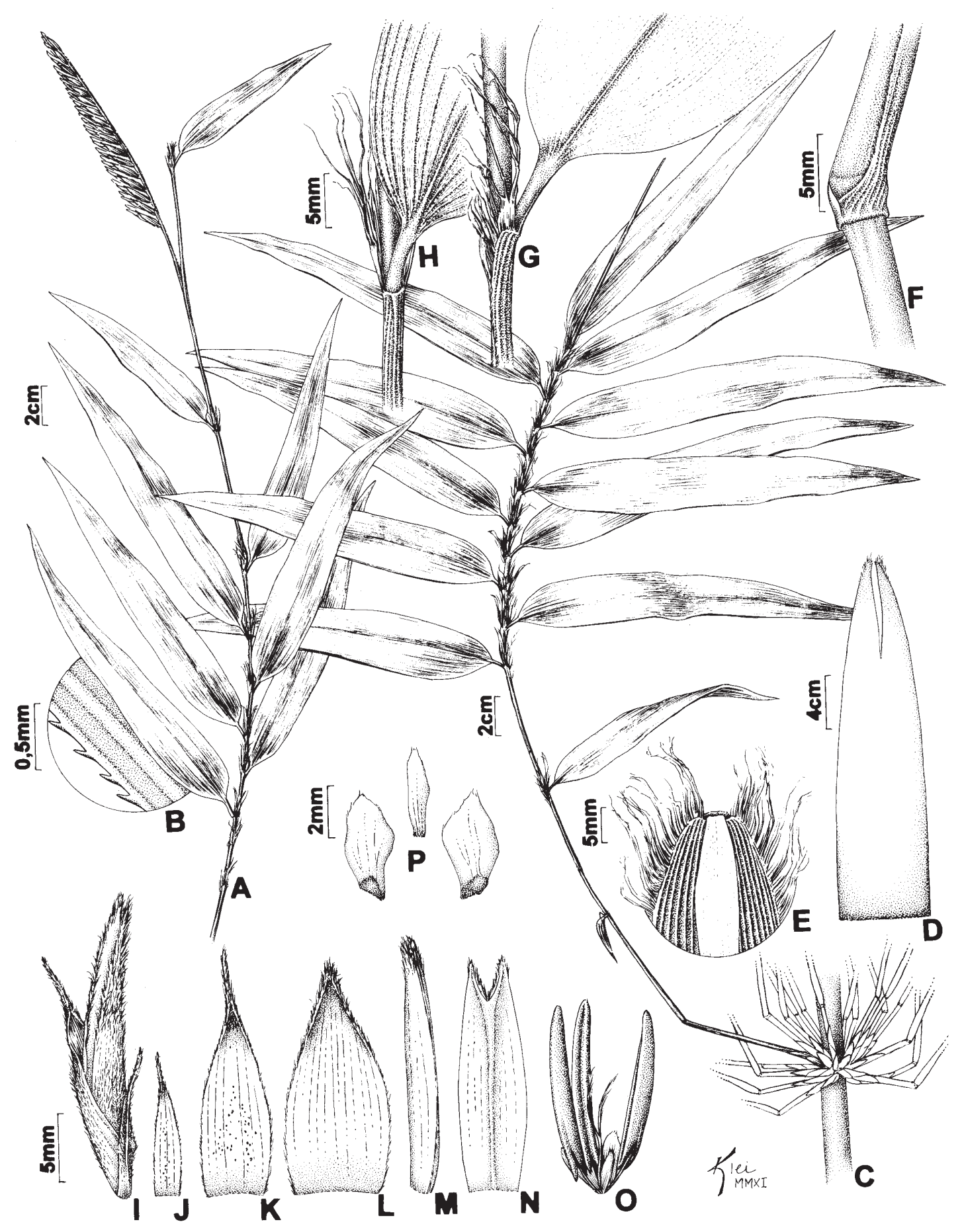

Figura 12. Merostachys speciosa. A. Ramo fértil. B. Margem da lâmina da folha do complemento de ramo. C. Complemento de ramo. D. Folha do colmo. E. Ápice da folha do colmo. F. Nó do complemento de ramo. G. Fímbrias da folha do complemento de ramo com detalhe da base da face adaxial da lâmina. H. Fímbrias da folha do complemento de ramo com detalhe da base da face abaxial da lâmina. I. Espigueta. J. Gluma I. K. Gluma II. L. Lema. M. Pálea. N. Pálea aberta. O. Flor. P. Lodículas. (P.K. Dusén 17348- parte fértil; R.T. Shirasuna 2796- parte vegetativa).

Figure 12. Merostachys speciosa. A. Fertile branch. B. Blade margin of foliage leaf. C. Branch complement. D. Culm leaf. E. Apex of the culm leaf. F. Node of the branch complement. G. Fimbriae of foliage leaf, with base detail of the blade, adaxial face. H. Fimbriae of foliage leaf, with base detail of the blade, abaxial face. I. Spikelet. J. Glume I. K. Glume II. L. Lemma. M. Palea. N. Palea. O. Flower. P. Lodicules. (P.K. Dusén 17348- fertile organs; R.T. Shirasuna 2796- vegetative organs). 
Ocorre no bioma Mata Atlântica com distribuição conhecida nas regiões sudeste (MG, SP) e sul (PR, RS, SC) (Sendulsky 2001, Shirasuna 2012b).

No PEFI foi coletada em apenas dois pontos com uma touceira cada, todas em floresta em estágio secundário médio.

Conhecida como taquara (Filgueiras \& SantosGonçalves 2006), taquara-póca (McClure \& Smith 1967).

A espécie nunca foi registrada fértil no PEFI, mas há registros de materiais adicionais férteis dos anos de 1915, 1925 e 1962. Estes dados são insuficientes para se determinar o padrão fenológico da espécie.

A espécie não consta do Livro Vermelho das Espécies Vegetais Ameaçadas do Estado de São Paulo (Mamede et al. 2007), esta avaliação é confirmada no presente estudo.

3. Chusquea Kunth, J. Phys. Chim. Hist. Nat. Arts 95: 151.1822.

Caracteres diagnósticos: rizoma paquimorfo, raro leptomorfo e anfimorfo, entrenós sólidos, ramificação infravaginal, extravaginal ou intravaginal, complemento de ramo com inserção constelada, folhas do colmo: bainha com fímbrias apicais nulas, aurículas nulas, folhas dos complementos de ramos: bainha sem fímbrias apicais, às vezes, com pequeno tufo de pêlos no ápice, aurículas nulas, sinflorescência paniculada, capitada, raro racemosa, laxa a contraída, determinada, terminal, espiguetas bissexuadas, acrótonas, glumas 2 desiguais; lemas estéreis 2 , pálea nula, antécio fértil 1; lema 1; pálea 1; extensão de ráquila nula, antécio apical rudimentar nulo.

Chusquea é o segundo gênero mais especioso dos bambus lignificados do Novo Mundo e do Brasil (Judziewicz et al. 2000). Exclusivamente do Continente Americano, ocorre do México até Argentina e Chile (McClure 1973, Clark 1995, Judziewicz et al. 1999), desde o nível do mar até 4.000 m.s.m.

No Brasil ocorre nos biomas da Amazônia, Cerrado e Mata Atlântica com distribuição no norte (AM, RO), nordeste (BA), sudeste (ES, MG, RJ, SP) e sul (PR, RS, SC) (Shirasuna 2012a). O sudeste do Brasil parece ser um centro de diversidade do gênero com 40 espécies descritas (Filgueiras \& SantosGonçalves 2004), embora os Andes também sejam considerados o principal centro de diversidade deste gênero (Clark 1995).

No PEFI registra-se a ocorrência de três espécies, todas com ramificação infravaginal.
Chave para identificação das espécies de Chusquea ocorrentes no PEFI

1. Lâmina das folhas dos complementos de ramos com um tufo de tricomas na base da face abaxial 3. C. meyeriana

1. Lâminas das folhas dos complementos de ramos sem um tufo de tricomas na base da face abaxial

2. Folhas dos complementos de ramos 4-7 por complemento de ramo; lâminas pubescentes na face abaxial; bainha densamente pilosa a escabra; lígula interna com margem glabra; sinflorescência capitada, 1-3 cm compr. 2. C. capituliflora var. pubescens

2. Folhas dos complementos de ramos 10-13 por complemento de ramo; lâminas glabras em ambas as faces; bainha escabra; lígula interna com margem ciliolada; sinflorescência sublaxa, 4,5-8,5 cm compr. ...... 1. C. bambusoides

3.1. Chusquea bambusoides (Raddi) Hack., Ergebn. Bot. Exp. Sudbras. 1: 20. 1906.

Figura 13

Rizoma paquimofo, pescoço curto. Colmos 2-10 m compr., apoiantes com ápice escandentes; entrenós 22-33 cm compr., cilíndricos, sólidos, lisos a escabros inferiormente a linha nodal. Linha nodal assimétrica, irregular, contornando abaixo da gema do ramo complementar, saliente, glabra, castanhoclara, região nodal 2-4 mm, glabra, verde-clara; anel supranodal inconspícuo; ramificação infravaginal. Folhas do colmo persistentes, não pseudopecioladas; bainha 16-19 × 0,9-1,8 cm, não aderentes, face abaxial escabra, castanho-clara com algumas manchas mais escuras, face adaxial glabra, brilhante, margem glabra a pilosa; lâmina 1,5-2,9 × 0,2-1,9 cm, triangular, ápice setosa, castanho-clara, glabra a escabra, tardiamente caduca, séssil, ereta. Complemento de ramo (3-)5-12 ramos subsidiários subiguais, com nós geniculados, dispostos em uma fileira curva ao redor do ramo central, com crescimento verticilado, dando aspecto aracnóide, podendo apresentar ramificações sucundárias, ca. $40 \mathrm{~cm}$ compr., 10-13 lâminas por ramo. Folhas dos ramos: bainha sem tricomas no ápice, glabra, maculada de verde, margem pilosa; lígula externa 0,4-1 mm larg., assimétrica, arredondada, ereta a patente, verde-clara, glabra; lígula interna 1-2,5 mm larg., assimétrica, obtusa, membranosociliolada; pseudopecíolo 1-3 mm compr., verde, glabro 


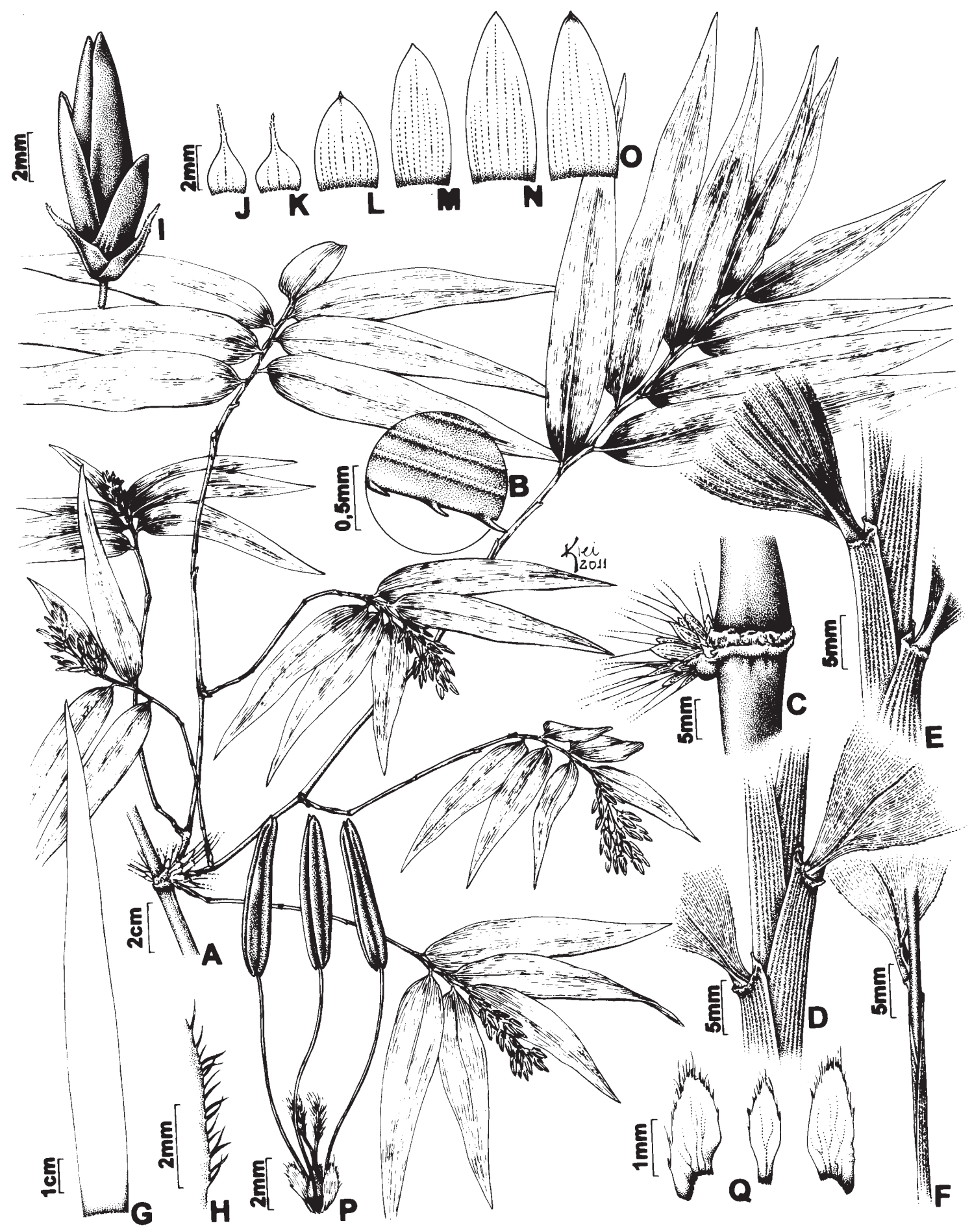

Figura 13. Chusquea bambusoides. A. Ramo fértil. B. Margem da lâmina da folha do ramo. C. Nó do colmo com complemento de ramos. D. Detalhe da lígula externa e base da face adaxial da lâmina do complemento de ramo. E. Detalhe da base abaxial da lâmina do complemento de ramo. F. Detalhe da margem da bainha do complemento de ramo. G. Folha do colmo. H. Margem da bainha da folha do colmo. I. Espigueta. J. Gluma I. K. Gluma II. L. Lema I. M. Lema II. N. Lema fértil. O. Pálea. P. Flor. Q. Lodículas. (T. Sendulsky 1402).

Figure 13. Chusquea bambusoides. A. Fertile branch. B. Blade margin of the blade foliage leaf. C. Node of the culm with branch complement. D. Detail of the external ligule and the adaxial face of the blade base of foliage leaf. E. Detail of foliage leaf blade, abaxial face. F. Margin detail of foliage leaf sheath. G. Culm leaf. H. Margin of the culm leaf. I. Spikelet. J. Glume I. K. Glume II. L. Lemma I. M. Lemma II. N. Fertile lemma. O. Palea. P. Flower. Q. Lodicule. (T. Sendulsky 1402). 
em ambas as faces; lâminas 6,5-21,5 × 1,2-5 cm, oblongo-lanceoladas, glabras em ambas as faces, margem lisa a escabra, sem um tufo de tricomas na base da face abaxial. Panícula 4,5-8,5 cm compr., sublaxas, terminais, espiguetas não adpressas aos ramos. Espiguetas 7-9(-10) mm compr.; gluma I, 2,8-3,8 mm compr., 3-nervada, aristada, arista 1-1,2 mm compr., tricomas concentrado no ápice da nervura principal; gluma II, 3-3,9 mm compr., 3-5-nervada, aristada, arista ca. $1 \mathrm{~mm}$ compr., glabra ou tricomas no ápice da nervura principal; lema I, 4,2-4,8(-5,8) mm compr., ca. 9-nervado, ápice obtuso a mucronado, jovens maculados de verde-escuro, glabro, ápice híspido; lema II, 6,8-7,3 mm compr., 9-11-nervado, ápice obtuso a mucronado, híspido; lema fértil, 8-8,2 mm compr., 11-15-nervado, ápice obtuso, glabro; pálea 6,5-8 mm compr., 6-nervada, ápice obtuso, glabro, face adaxial escabra entre as duas nervuras medianas; lodículas 2-2,4 mm compr., lanceoladas, margem ciliolada; anteras 3,5-4,8 mm compr., castanhas. Cariopse não vista.

Material examinado: BRASIL. São Paulo: São Paulo, Parque Estadual das Fontes do Ipiranga, IBt, 14-V-1974, fl., T. Sendulsky 1401 (SP); IBt, 14-V-1974, fl., T. Sendulsky 1402 (SP); IBt, 30-XI-2005, veg., R.T. Shirasuna \& F. Vitta 128 (SP); IBt, 1959, fl., s.col. s.n. (SP153839); IBt, 16-VII-1974, fl., M. Sakane 109 (SP); IBt, 10-V-1943, fl., O. Handro s.n. (ISC, SP48302, SPF); IBt, 21-X-2008, fl., R.T. Shirasuna 1809 (SP); IBt, 24-III-2010, fl., R.T. Shirasuna 2818 (SP).

Chusquea bambusoides está inserida no clado Chusquea subg. Rettbergia (Fisher et al. 2009). Assemelha-se a C. capituliflora var. pubescens pelo hábito pendente a escandente com folhas do colmo persistentes, eretas, não pseudopecioladas com pouca distinção entre a bainha e lâmina. Distingue-se desta por apresentar os entrenós glabros a híspidos (e não pubescentes a escabros); as bainhas do colmo escabras na face abaxial (e não densamente pilosa); lâmina dos ramos glabra sem um tufo de tricomas na base da face abaxial (e com um tufo de tricomas na base da face abaxial); sinflorescências panícula sublaxas (e não capitadas).

A cariopse desta espécie ainda não é conhecida. No material examinado nenhuma cariopse foi encontrada.

No Brasil C. bambusoides ocorre no bioma Mata Atlântica com distribuição conhecida nas regiões nordeste (BA), sudeste (ES, SP, RJ) e sul (PR, RS, SC) (Shirasuna 2012a).

No PEFI foi coletada em 10 pontos. Está concentrada somente na região nordeste em área do IBt, principalmente na floresta em estádio secundário tardio.

Devido a sua recente (2010) reprodução no PEFI, durante os trabalhos de campo, quase toda a população encontrou-se em estágio de plântula.

Conhecida como criciúma (McClure \& Smith 1967), taboca (Filgueiras \& Santos-Gonçalves 2006).

No PEFI, foi registrada fértil nos anos de 1943, 1959, 1974, 2008 e 2010. Parece ser uma espécie com florescimento mais ou menos frequente com ciclos de poucos anos (Clark 2001), porém os dados disponíveis sugerem um ciclo entre 15-17 anos.

A espécie não consta do Livro Vermelho das Espécies Vegetais Ameaçadas do Estado de São Paulo (Mamede et al. 2007), esta avaliação é confirmada no presente estudo.

\subsection{Chusquea capituliflora Trin. var. pubescens}

McClure \& L.B. Sm., Fl. Il. Catarin. Gram. Suppl.: 28. 1967.

Figura 14

Rizoma paquimorfo, pescoço curto. Colmos 4-10 m compr., apoiantes, ápice escandentes; entrenós 24-27 cm compr., cilíndricos, sólidos, pubescentes a escabros. Linha nodal assimétrica, irregular, contornando abaixo da gema do ramo complementar, saliente, com tricomas esparsos, castanho-vinácea, região nodal ca. $5 \mathrm{~mm}$, glabra, verde-clara; anel supranodal conspícuo, ramificação infravaginal. Folhas do colmo persistentes, não pseudopecioladas, bainha 12-25,7 × 1-2,7 cm, não aderente, face abaxial densamente tuberculoso-piloso e escabroso, castanho com pontuações escuras, face adaxial glabra, castanho-brilhante, margem pilosa; lâmina 2,5-9,7 $\times 0,4-0,5 \mathrm{~cm}$, lanceolada, castanho-clara, escabra, tardiamente caduca, séssil, ereta, ápice setoso. Complemento de ramo (5-)10-30 ramos subsidiários subiguais, nós basais geniculados, dispostos em 1-2 fileiras curvas ao redor do ramo central, dando aspecto aracnoide, alguns com ramificação secundária, 10-30 cm compr., 4-7 lâminas por ramo. Folhas dos complementos de ramos: bainha com finos tricomas no ápice, pubescentes, com máculas esverdeadas, margem ciliada ou não; lígula externa ca. 0,3 $\mathrm{mm}$ larg., assimétrica, arredondada, ereta a patente, verde-clara, glabra ou uma faixa de tricomas; 


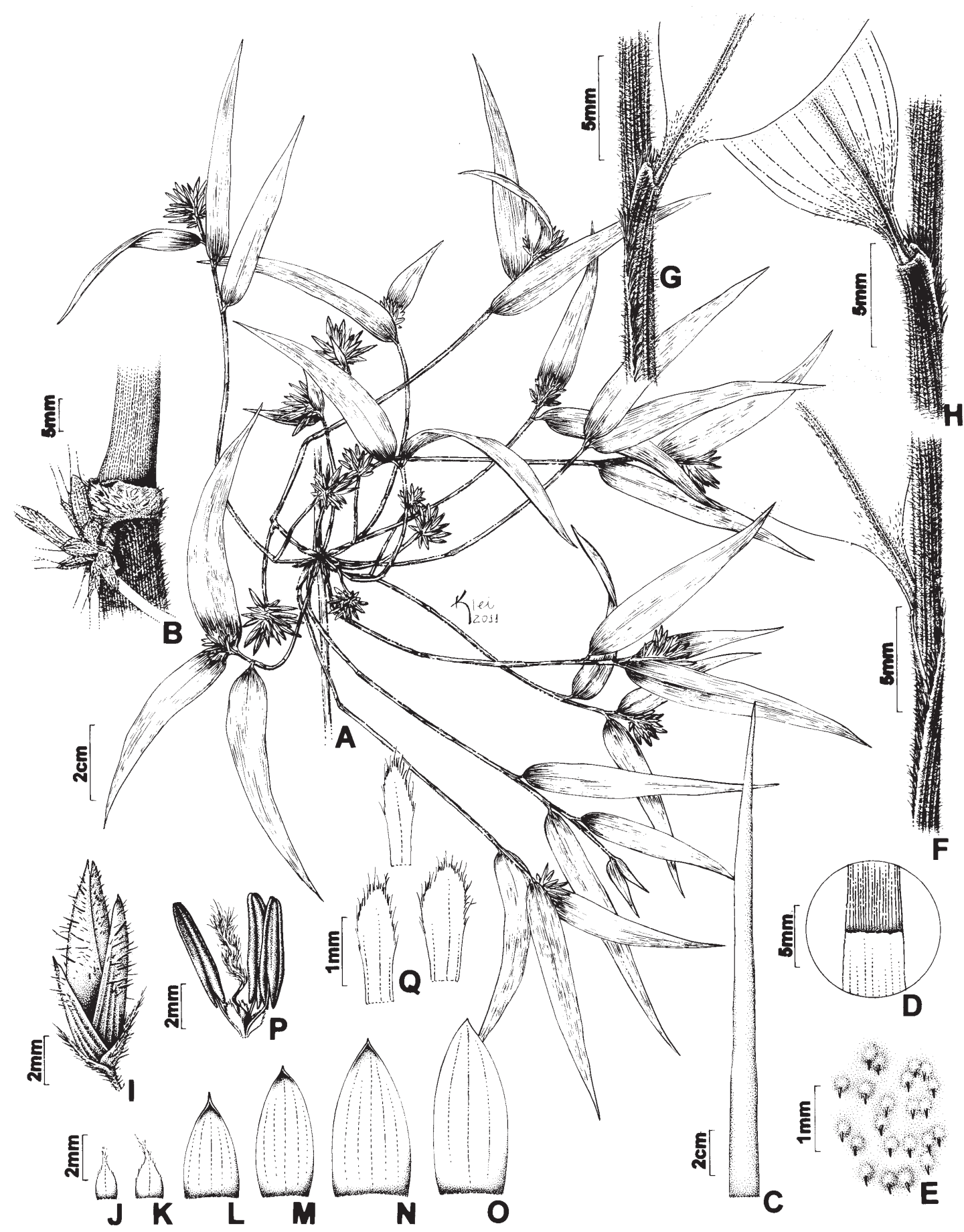

Figura 14. Chusquea capituliflora var. pubescens. A. Ramo fértil. B. Nó do colmo e complemento de ramos. C. Folha do colmo. D. Lígula interna da folha do colmo. E. Detalhe da superfície dorsal da bainha da folha do colmo. F. Detalhe da margem da bainha do complemento de ramo. G. Detalhe da lígula externa e base da face adaxial da lâmina do complemento de ramo. H. Detalhe da lígula externa e base da face abaxial da lâmina do complemento de ramo. I. Espigueta. J. Gluma I. K. Gluma II. L. Lema I. M. Lema II. N. Lema fértil. O. Pálea. P. Flor. Q. Lodículas. (R.T. Shirasuna \& F. Vitta 125; R.T. Shirasuna 2880- somente a folha do colmo).

Figure 14. Chusquea capituliflora var. pubescens. A. Fertile branch. B. Node of the culm and branch complement. C. Culm leaf. D. External ligule of culm leaf. E. Detail of culm leaf sheath, dorsal surface of the sheath of culm leaf. F. Margin detail of foliage leaf sheath. G. Detail of the external ligule and the adaxial face of the blade base of foliage leaf. H. Detail of the external ligule and the abaxial face of the blade base of foliage leaf. J. Glume I. K. Glume II. L. Lemma I. M. Lemma II. N. Fertile lemma. O. Palea. P. Flower. Q. Lodicules. (R.T. Shirasuna \& F. Vitta 125 ; R.T. Shirasuna 2880- culm leaf). 
lígula interna 0,8-1,2 mm larg., assimétrica, truncada, membranosa com margem inteira; pseudopecíolo 1-2 mm compr., verde-acastanhado, glabro a híspido em ambas as faces; lâminas 6,5-15,6 × 1-1,5(-2,4) cm, lanceoladas, glabras em ambas as faces ou face abaxial hirsuta, margem lisa a escabra, às vezes com um tufo de tricomas na base da face abaxial. Panícula 1-3 cm compr., capitada, terminal, espiguetas não adpressas aos ramos. Espiguetas (4-)6-8 mm compr.; gluma I, 2-4(-5) mm compr., 1-3-nervada, aristada, arista 1-1,8 $\mathrm{mm}$, pilosa; gluma II, 2-4 mm compr., 3-5-nervada, aristada, arista 1-1,8 mm, pilosa; lema I, 3-4,8 mm compr., 5-7-nervado, aristada, arista ca. $1 \mathrm{~mm}$, piloso; lema II, 5-6 mm compr., 7-nervado, ápice mucronado, glabro a metade superior piloso; lema fértil ca. $7 \mathrm{~mm}$ compr., 9-nervado, apiculado, glabro a metade superior piloso; pálea ca. $7 \mathrm{~mm}$ compr., 2-nervada, ápice obtuso, glabra, somente ápice híspido; lodículas 1,5-1,7 mm compr., lanceoladas, margem cilioladas; anteras ca. 4,5 mm compr., castanhas. Cariopse não vista.

Material examinado: BRASIL. São PAUlo: São Paulo, Parque Estadual das Fontes do Ipiranga, IBt, 15-VI-1926, fl., F.C. Hoehne s.n. (SP17392); IBt, 10-I-1942, fl., F.C. Hoehne s.n. (SP46306, SPF); IBt, 10-VII-1974, fl., T. Sendulsky 1422 (ISC, SP); IBt, 12-X-1974, fl., T. Sendulsky 1289 (SP); IBt, 6-XII-1974, fl., T. Sendulsky 1431 (SP); IBt, 23-IV-1974, fl., T. Sendulsky 1392 (SP); IBt, 5-IX-1974, fl., T. Sendulsky 1423 (SP); IBt, 12-X-1974, fl., T. Sendulsky 1289 (SP); IBt, 30-IX-1974, fl., T. Sendulsky 1424 (SP); IBt, 19-VII-1974, fl., T. Sendulsky 1421 (SP); IBt, 9-IV-1974, fl., T. Sendulsky 1369 (SP); IBt, 24-IX-1974, fl., T. Sendulsky 1424A (SP); IBt, 9-II-2010, veg., R.T. Shirasuna 2760 (SP); Cien Tec, 5-VIII-2010, veg., R.T. Shirasuna 2867 (SP); Cien Tec, 26-VIII-2010, veg., R.T. Shirasuna 2880 (SP); IBt, 17-XI-2009, fl., R.T. Shirasuna 2652 (SP); IBt, 18-II-2009, fl., R.T. Shirasuna 2169 (SP); IBt, 21-X-2008, fl., R.T. Shirasuna \& A. Costa 1808 (SP); IBt, 22-X-2009, fl., R.T. Shirasuna 2606 (SP); 30-XI-2005, fl., R.T. Shirasuna \& F. Vitta 125 (SP).

A variedade típica ( $C$. capituliflora var. capituliflora) apresenta as folhas dos ramos com bainhas e lâminas glabras, espiguetas com lema I, 4/5 do comprimento da espigueta e lema II subigual ao tamanho da espigueta. Esta não ocorre no PEFI. Somente C. capituliflora var. pubescens ocorre no PEFI, com bainhas dos ramos geralmente pubescentes, às vezes glabras, lâminas dos ramos pubescentes na face abaxial; lema I, 1/2 do comprimento da espigueta e lema II, 3/4 do tamanho da espigueta (Clark 2001).

A cariopse desta espécie ainda não é descrita. No material examinado nenhuma cariopse foi encontrada.

No Brasil Chusquea capituliflora var. pubescens é nativa do bioma Mata Atlântica com distribuição conhecida nas regiões sudeste (MG, RJ, SP) e sul (PR, RS, SC) (Shirasuna 2012a).

No PEFI foi coletada em 40 pontos e está amplamente distribuída em praticamente todas as partes da floresta em estádio secundário inicial e secundário médio. Devido à recente reprodução, todas as populações estavam em estágio de plântula ou ainda muito jovens. Uma quantidade muito grande de plântulas foi vista desenvolvendo-se em meio à floresta.

Conhecida como bambu-trepador (http:// pt.wikipedia.org/wiki/Bambu-trepador), gurixima (http://pt.wikipedia.org/wiki/Bambu-trepador), criciúma (http://pt.wikipedia.org/wiki/Bambutrepador), quixiúme (http://pt.wikipedia.org/wiki/ Bambu-trepador), taquari (Garcia, R.J.F. 99), taboca (Filgueiras \& Santos-Gonçalves 2006), taquarinha (http://pt.wikipedia.org/wiki/Bambu-trepador).

No PEFI, foi registrada fértil nos anos de 1926, 1942, 1974, 2005, 2008 e 2009. Esse padrão sugere um ciclo de vida de 16 anos podendo ocorrer florescimento esporádico (Clark 2001), sendo que nos anos de 1958 e 1990 deve ter ocorrido novo ciclo reprodutivo no PEFI, porém, não registrado nos herbários consultados. O holótipo (Klein, R.M. 572, US) e a coleta Reitz \& Klein 6203 , HBR, US) confirmam o ciclo de 16 anos.

A espécie não consta do Livro Vermelho das Espécies Vegetais Ameaçadas do Estado de São Paulo (Mamede et al. 2007), esta avaliação é confirmada no presente estudo.

3.3. Chusquea meyeriana Rupr. ex Döll, Fl. Bras. 2(3): 203, 1880.

Figura 15

Rizoma paquimorfo, pescoço curto. Colmos 3-6 m alt., eretos na base, arqueados a apoiantes na parte superior, ápice de alguns ramos podem ser escandentes; entrenós 16-19 cm compr., cilíndricos, sólidos, lisos, glabros, mais jovens com cera esbranquiçada. Linha nodal assimétrica, irregular, contornando abaixo da gema do ramo complementar, saliente, glabra, acastanhada, região nodal 0,7-0,9 mm glabra, verde-acastanhada; anel supranodal conspícuo; ramificação infravaginal. Folhas do colmo persistentes a tardiamente decíduas, não pseudopecioladas, 


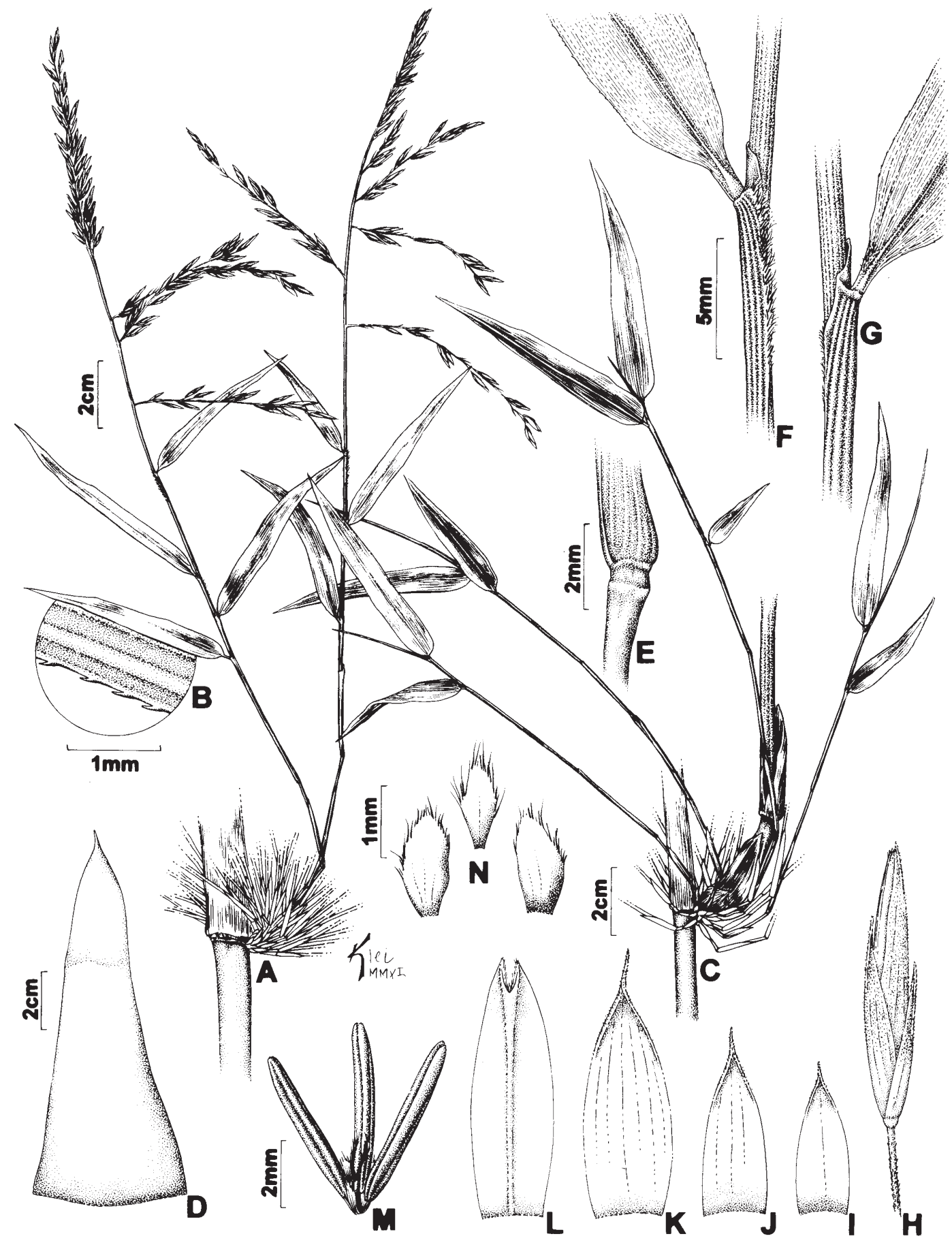

Figura 15. Chusquea meyeriana. A. Ramo fértil. B. Margem da lâmina da folha do complemento de ramo. C. Complemento de ramo evidenciando um ramo dominante. D. Folha do colmo. E. Nó do complemento de ramo. F. Detalhe da lígula interna e base da face adaxial da lâmina do complemento de ramo. G. Detalhe da lígula externa e base da face abaxial da lâmina do complemento de ramo. H. Espigueta com glumas escamiformes (cf. seta). I. Lema I. J. Lema II. K. Lema fértil. L. Pálea. M. Flor. N. Lodículas. (L. Kinoshita \& A. Tozzi 95-63, R.T. Shirasuna 2697- somente a folha do colmo).

Figure 15. Chusquea meyeriana. A. Fertile branch. B. Blade margin of foliage leaf. C. Branch complement with dominant branch. D. Culm leaf. E. Node of the branch complement. F.Detail of the inner ligule and the adaxial face of the face of the blade base of foliage leaf. G. Detail of the external ligule and the abaxial face of the blade base of foliage leaf. H. Spikelet with scaly glumes (cf. arrow). I. Lemma I. J. Lemma II. K. Fertile lemma. L. Palea. M. Flower. N. Lodicules. (L. Kinoshita \& A. Tozzi 95-63, R. T. Shirasuna 2697- culm leaf). 
adaxialmente com fraca distinção entre bainha e lâmina; bainha 9-9,5 × 2,3-2,8 cm, não aderentes, face abaxial glabra, às vezes escabras, castanhoclara, adaxial glabra, brilhante, margem glabra; lâmina ca. 4,4 × 1,5 cm, lanceolada, castanhoclara, glabra, tardiamente caduca, séssil, ereta, ápice agudo-acuminada. Complemento de ramo 15-60 ramos subsidiários, subiguais, eretos ou com nós geniculados, podendo apresentar ramificação secundária, dispostos em mais de uma fileira abaixo do ramo dominante, 25-40 cm compr., 5-9(-12) lâminas por ramo. Folhas dos complementos de ramos: bainha; sem tricomas no ápice, glabra, verde ou manchada de verde-escuro, as mais velhas com porção apical vinácea, margem finamente ciliolada; lígula externa 0,7-0,9 mm larg., assimétrica, arredondada, ereta, verde-vinácea, glabra; lígula interna 1,5-2,5 mm larg., assimétrica, arredondada, membranosa; pseudopecíolo 1-2,5 mm compr., vináceo, glabros em ambas as faces; lâminas 7-13 × 1,2-1,8 cm, lanceolada, glabras em ambas as faces, margem escabra, com um tufo de tricomas na base da face abaxial. Panícula 5-14 cm compr., laxa, terminal, espiguetas adpressas aos ramos. Espiguetas (6-)8-10 mm compr., híspidas; gluma I, 0,1-0,4 mm compr., enérvea, obtusa, glabra; gluma II, 0,2-0,4 mm compr., enérvea, obtusa, glabra; lema I, 3-4 mm compr., 3-5-nervada, mucronado, híspido, escabro sobre a nervura principal; lema II, 5-6 mm compr., 5-7-nervado, mucronado, glabro, híspido na metade superior; lema fértil 7-10 mm compr., 7-nervado, mucronado, híspido somente no ápice; pálea 7,2-10 mm compr., biquilhada, múcron bifurcado, finamente híspida; lodículas 1,5-2 mm compr., lanceoladas, fimbriadas nas margens; anteras ca. $6 \mathrm{~mm}$ compr., alaranjadas. Cariopse não vista.

Material examinado: BRASIL. São PaUlo: São Paulo, Parque Estadual das Fontes do Ipiranga, IBt, 5-V-1990, fl., L. Clark \& P. Windisch 732 (ISC, SP); IBt, 28-II-1992, fl., L. Clark \& X. Londoño 1054 (SP); IBt, 11-III-1994, fl., L. Clark 1213 (SP); IBt, 6-II-2009, veg., M.T. Grombone s.n. (SP412118); IBt, I-1992, fl., T. Sendulsky s.n. (SP258130); Cien Tec, 29-VII-2010, veg., R.T. Shirasuna 2862 (SP); IBt, 14-XII-2009, veg., R.T. Shirasuna 2697 (SP); IBt, 4-XI-2009, veg., R.T. Shirasuna 2618 (SP); IBt, 24-VI-2005, veg., R.T. Shirasuna 109 (SP); IBt, 24-VI-2005, veg., R.T. Shirasuna 112 (SP).

Chusquea meyeriana assemelha-se a C. capituliflora var. pubescens por apresentar um tufo de tricomas na face abaxial das lâminas.
Assemelha-se também a $C$. bambusoides por apresentar rizoma paquimorfo com pescoço curto, linha nodal asssimétrica, saliente e glabra.

Chusquea meyeriana difere das outras espécies de Chusquea do PEFI por apresentar hábito arqueado a apoiante e não escandente. Difere de $C$. capituliflora var. pubescens por esta apresentar a linha nodal com tricomas esparsos e não linha nodal glabra.

O nome Chusquea meyeriana deverá ser lectotipificado pelo fato de existirem quatro síntipos. Este procedimento será feito oportunamente.

A cariopse desta espécie ainda não foi descrita. No material examinado nenhuma cariopse foi encontrada.

No Brasil Chusquea meyeriana encontra-se no domínio da Mata Atlântica com distribuição conhecida nas regiões sudeste (MG, SP, RJ) e sul (PR, RS, SC) (Shirasuna 2012a). No PEFI foi coletada em 25 pontos e está bem distribuída. É a única espécie de Chusquea do PEFI que durante o período de coletas encontrava-se em estágio vegetativo bem desenvolvido (4-5 $\mathrm{m}$ altura).

Conhecida como: caará (Dutra 1938), criciúma (McClure \& Smith 1967), taboca (Filgueiras \& Santos-Gonçalves 2006).

No PEFI Chusquea meyeriana foi registrada fértil nos anos de 1990, 1992 e 1994. Materiais adicionais registram floração nestes mesmos anos, inclusive 1995. Esses dados são insuficientes para determinar o ciclo de vida desta espécie. Mais estudos e coletas são necessários para se tirar conclusões sobre o padrão fenológico da espécie.

A espécie não consta do Livro Vermelho das Espécies Vegetais Ameaçadas do Estado de São Paulo (Mamede et al. 2007), esta avaliação é confirmada no presente estudo.

\section{Tribo Olyreae Kunth}

No PEFI registra-se a ocorrência de dois gêneros Olyra e Parodiolyra.

Chave de identificação para os gêneros da tribo Olyreae ocorrentes no PEFI

1. Sinflorescências terminais; espiguetas femininas com pedicelo clavado e maiores do que as masculinas, desarticulação acima das glumas; hilo alongado, atingindo todo o comprimento da cariopse ......................... 4. Olyra

1. Sinflorescências terminais e axilares; espiguetas femininas com pedicelo filiforme e do mesmo tamanho que as masculinas, desarticulação abaixo das glumas; hilo curto, atingindo, no máximo, $3 / 4$ do comprimento da cariopse ...................................... 5. Parodiolyra 
4. Olyra L., Syst. Nat. (ed. 10): 1253, 1261, 1379. 1759.

Caracteres diagnósticos: colmos monomórficos, dimorficos até trimorficos, entrenós fistulosos, aurículas presentes ou nulas, sinflorescências panículas laxas a contraídas ou racemos contraídos, determinadas, terminais e ou axilares, ramos inferiores com espiguetas masculinas, com ou sem espigueta feminina terminal ou os superiores com masculinas inferiormente e ou 1-8 femininas terminais, pedicelos clavados, espiguetas unissexuadas, espiguetas femininas geralmente maiores que as masculinas, desarticulando acima das glumas, antécios férteis 1 , estigmas 2, espiguetas masculinas geralmente menores que as femininas.

O gênero Olyra apresenta ca. 23 espécies florestais nos Neotrópicos, do México ao sudeste dos Estados Unidos até a Argentina (Oliveira \& LonghiWagner 2001).

No Brasil Olyra está representado por 20 espécies distribuidas nos seguintes domínios fitogeográficos: Amazônia, Caatinga, Cerrado, Mata Atlântica e Pantanal com ocorrência nas regiões norte (AC, AM, AP, PA, RO, RR), nordeste (BA, CE, MA, PE, SE), centro-oeste (DF, GO, MS, MT), sudeste (ES, MG, RJ, SP) e sul (PR, RS, SC) (Filgueiras \& Oliveira 2012a).

No PEFI está representado por três espécies $O$. glaberrima Raddi, $O$. humilis Nees e $O$. loretensis Mez.

Chave para identificação das espécies de Olyra ocorrentes no PEFI

1. Colmos dimórficos, os vegetativos com lâminas e reprodutivos sem lâminas ou com lâminas rudimentares; espiguetas masculinas 2-2,5 mm compr. 4.3. O. loretensis

1. Colmos monomórficos, os vegetativos e reprodutivos com lâminas, sem distinção entre os vegetativos e reprodutivos; espiguetas masculinas 5-8(-10) mm compr.

2. Lâminas 4,5-12 × 1,4-3,4 cm, face adaxial escabra ..................................... 4.2. O. humilis

2. Lâminas $12-24 \times 3,5-6,6 \mathrm{~cm}$, face adaxial glabra 4.1. O. glaberrima

4.1. Olyra glaberrima Raddi, Agrostogr. Bras.: 19. 1823.

Figura 16

Rizoma curto. Colmos monomórficos, 50-200 cm compr., eretos, pouco geniculados nos nós inferiores; entrenós 2-33 cm compr., inferiores mais curtos e medianos maiores, cilíndricos, fistulosos, glabros a curtamente pubescentes, verde-acastanhados às vezes com máculas esverdeadas, superfície lisa. Linha nodal horizontal, aneliforme, glabra, vinácea. Folhas de ramo: bainha 6-30 × 0,9-1,2 cm, glabra, raro híspido-pilosa, verde a vinácea, fortemente estriada, margens glabras a longo-ciliadas, densamente em direção ao ápice; aurículas membranosas; pseudopecíolo (-1,5)2-5(-6) mm compr., híspidos a densamente pubescentes em ambas as faces com curtos tricomas esbranquiçados; lígula interna 0,4-1 mm compr., membranosa com margem finamente ciliolada; lâmina 12-24 × 3,5-6,6(-8,5) cm, oval-lanceolada, patente a deflexa, glabras em ambas as faces, não discolor, base assimétrica, truncada, ápice acuminado, margem escabérula a curtamente ciliolada. Panículas 9-20 cm compr., piramidal, laxa, difusa, terminal, ramos inferiores verticilados com numerosas espiguetas masculinas com uma feminina, terminal ou ramos superiores alternos com espiguetas masculinas inferiores e uma única feminina terminal. Pedicelo da espigueta feminina clavado, esparsamente híspido, pedicelo da espigueta masculina filiforme e escabro. Espiguetas femininas 12-17(-27) mm compr., fusiformes, oblongas, glumas desiguais, mais longas que o antécio, antécio fértil 1; gluma I, 9-21 mm compr. mais longa que a gluma II, 5-9-nervada, verde-oliváceo, glabra a escabra, aristada, arista (-2)3-7(-15) mm compr.; gluma II, (7-)9-10(-15) mm compr., 5-7-nervada, verde-oliváceo, glabra a escabérula, acuminada, raro aristada, arista 1-2 mm compr.; estípite nulo; antécio 5-7(-8) mm compr., esbranquiçado a estramíneo com máculas escuras na maturidade, lisa e brilhante, densamente pubescentes somente na base e ápice da superfície ventral; lema 5-7 mm compr., 5-nervado, com tricomas na base e ápice; pálea 5,8-6,8(-7,8) mm compr., 2-nervada, tricomas na base, esparsos em direção ao ápice a completamente glabra; estigmas plumosos; lodículas $0,6-0,8 \mathrm{~mm}$ compr., margem inteira, glabras. Espiguetas masculinas 5-8(-11) mm compr., lanceoladas, lema 6,5-9 mm compr., 3-nervado, castanho a vináceo, glabro, aristado, arista 0,8-2(-4) mm; pálea 5-6(-8,5) mm compr., 2-nervada, vinácea, glabra, acuminada a curto-aristada; lodículas 0,2-0,4 mm compr., margem inteira, glabras; anteras (3-)4-5,8(-6) mm compr., amarelo-alaranjadas. Cariopse 4,5-5,4 × ca. 2,8 mm, elíptica, hilo tão longo quanto à cariopse, castanha. 


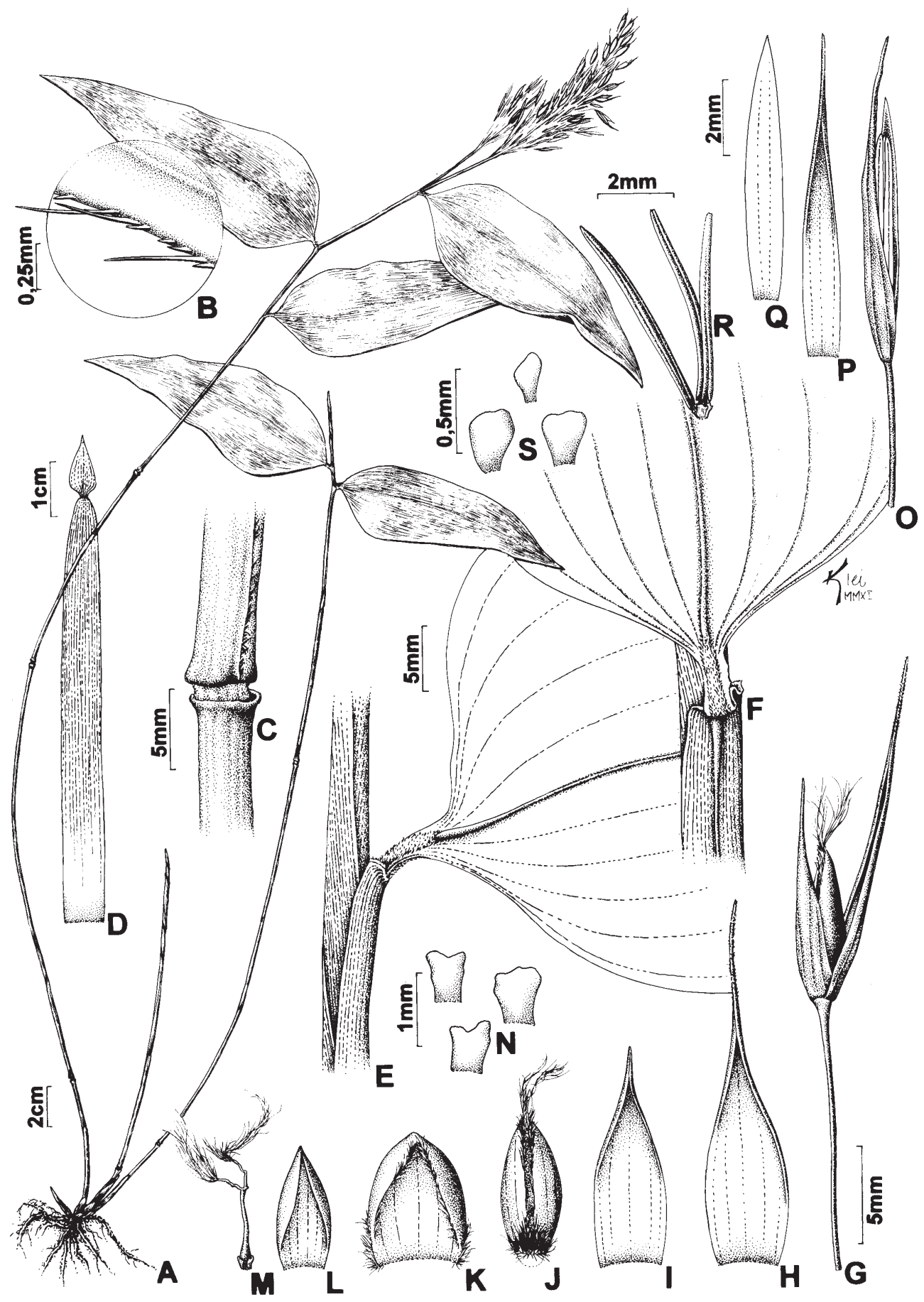

Figura 16. Olyra glaberrima. A. Hábito. B. Detalhe da margem da lâmina. C. Nó do colmo. D. Bainha com lâmina reduzida. E. Detalhe do pseudopecíolo e base da face adaxial da lâmina. F. Detalhe da face abaxial do pseudopecíolo e da base da face abaxial da lâmina. G. Espigueta feminina com pedicelo. H. Gluma I. I. Gluma II. J. Antécio com estígmas plumosos. K. Lema. L. Pálea. M. Flor feminina. N. Lodículas da flor feminina. O. Espigueta masculina com pedicelo. P. Lema. Q. Pálea. R. Flor masculina. S. Lodículas. (G. Davidse \& W.G. D’arcy 10424).

Figure 16. Olyra glaberrima. A. Habit. B. Edge detail of the blade. C. Node of the culm. D. Sheath with reduced blade. E. Detail of the pseudopetiole and the adaxial side of the blade base. F. Detail of the abaxial face of the pseudopetiole and the abaxial side of the blade. G. Female spikelet with pedicel. H. Glume I. I. Glume II. J. Anthoecium with plumose stigmas. K. Lemma. L. Palea. M. Female flower. N. Lodicules of the female flower. O. Male spikelet with pedicel. P. Lemma. Q. Palea. R. Male flower. S. Lodicules. (G. Davidse \& W.G. D'arcy 10424). 
Material examinado: BRASIL. São Paulo: São Paulo, Parque Estadual das Fontes do Ipiranga, IBt, 20-VII-1982, fl., T. Sendulsky 1904 (SP); IBt, 19-II-1978, fl., M. Kirizawa 410 (SP, HUEFS); IBt, 2-IV-1974, fl., T.S. Silva 177 (SP); IBt, 8-VIII-1979, fl., A. Custodio Filho 124 (SP); IBt, 18-V-1993, fl., R. Simão Bianchini \& L. Rossi 354 (SP); IBt, 30-XI-1965, fl., T. Sendulsky 276 (SP, HUEFS); IBt, 14-XI-1980, fl., A. Rosa \& J.M. Pires 3699 (SP, INPA); IBt, 1-IX-1982, fl., S. Romaniuc Neto 53 (SP, HUEFS); IBt, 8-V-1974, 1., T. Sendulsky 1400 (SP); IBt, 21-II-1976, fl., G. Davidse \& W.G. D'Arcy 10424 (SP); IBt, 2-II-1953, fl., D.M. Dedecca s.n. (SP118834); IBt, 23-XI-1966, fl., R. Faria \& O.G. Fonseca s.n. (SP99415); IBt, 9-I-1965, fl., W.D. Clayton \& G. Eiten 4188 (SP).

Olyra glaberrima assemelha-se a $O$. humilis em quase todos os caracteres, diferindo principalmente no tamanho e revestimento das lâminas. As plantas do PEFI de $O$. glaberrima apresentam lâminas maiores $(12-24 \times 3,5-6,6(-8,5) \mathrm{cm}) \mathrm{com}$ a face adaxial glabra versus lâminas menores (4,5-12(-14),5 × 1,4-3,4 cm) e face adaxial escabra em $O$. humilis. Estes carateres foram usados para distinguir as duas espécies.

Olyra glaberrima tem ocorrência conhecida nas florestas úmidas da Mesoamérica desde o México, Belize, Guatemala, Honduras, Peru e Brasil onde parece ter se espalhado a partir de uma das regiões para outras através das atividades humanas (Soderstrom et al. 1988, Oliveira \& Longhi-Wagner 2001). No Brasil ocorre no domínio da Mata Atlântica com distribuição conhecida nas regiões nordeste (BA, PE), sudeste (ES, MG, RJ, SP) e sul (SC) (Filgueiras \& Oliveira 2012a), em área alterada, subalagada e floresta úmida (Oliveira \& Longhi-Wagner 2001). O Parque Municipal Trianon situado na Avenida Paulista no centro financeiro da cidade de São Paulo, abriga duas populações desta espécie.

No PEFI foi coletada em 30 pontos, com ampla distribuição nas margens de mata e no sub-bosque. Desenvolve-se no sub-bosque das florestas em estádio secundário inicial, médio e tardio. É uma espécie nativa das florestas úmidas, sendo indicada para a restauração do sub-bosque das áreas degradadas e também para cultivo em locais sombreados e vasos para interiores.

Conhecida como taquarinha (D. Tarabay et al. s.n. SPF177388), taquinha (Filgueiras \& SantosGonçalves 2006), sarandira (s.col. s.n. SPF84299).

Coletada fértil o ano todo com maior frequência nos meses de novembro a fevereiro.
A espécie não consta do Livro Vermelho das Espécies Vegetais Ameaçadas do Estado de São Paulo (Mamede et al. 2007), esta avaliação é confirmada no presente estudo.

4.2. Olyra humilis Nees, F1. Bras. Enum. P1. 2: 304. 1829.

Figura 17

Rizoma curto ou longo. Colmos monomórficos, 20-100 cm compr., eretos ou geniculado-ascendentes; entrenós 5-16,5(-20,5) cm compr., cilíndricos, fistulosos, glabros a curto-híspidos com tricomas esbranquiçados, verdes. Linha nodal horizontal, aneliforme, glabra, castanha a negra. Folhas de ramo: bainha 4,5-14 × 0,3-0,6 cm compr., glabra, pilosa ou com tricomas papiloso-pilosos, castanhas com máculas esverdeadas, estriadas, margem cilioladas; aurículas nulas; pseudopecíolo 0,8-3 mm compr., densamente híspidos em ambas as faces com tricomas esbranquiçados; lígula externa nula; lígula interna 0,2-0,9 mm compr, membranosa, curto ciliolada no ápice; lâmina 4,5-12(-14) × 1,4-3,4 cm, ovallanceolada a lanceolada, patente, face adaxial escabra a completamente glabra, abaxial glabra a híspida, base assimétrica, truncada a arredondada, ápice acuminado, margem escabra. Panículas 6-10(-17) cm compr., piramidal, laxa, ramos difusos, terminal, inferiores verticilados a alternos, superiores alternos, cada ramo com numerosas espiguetas inferiormente masculinas aos pares (um curto e outro longo-pedicelado) e uma única espigueta feminina terminal. Pedicelo da espigueta feminina espessado no ápice, liso e glabro, pedicelo da espigueta masculina filiforme e escabro. Espiguetas femininas 13-16(-19) mm compr., fusiformes, oblongas, glumas desiguais, geralmente mais longas que o antécio; antécio fértil 1; gluma I, (7-)9-10(-14) mm compr., 5-7-nervada, verdeoliváceo, curto-pilosa a escabra na superfície interna e glabra a escabérula na superfície externa, algumas aristas geniculadas, arista 3-4(-11) mm; gluma II, (7-)9-12 mm compr., 5-7-nervada, verde-olivácea, curto pilosa a escabra na superfície interna e glabra a escabérula na superfície externa, acuminada; estípite nula; antécio (5-)6-6,5(-7) mm compr., esbranquiçado, liso e brilhante, tricomas longos e esbranquiçados a acastanhados somente na base e ápice da superfície ventral; lema 6-6,5 mm compr., 5-nervado, superfície dorsal com tricomas esparsos a glabros; pálea 5-6(-6,8) mm compr., 2-nervadas com tricomas achatados em direção ao ápice, 


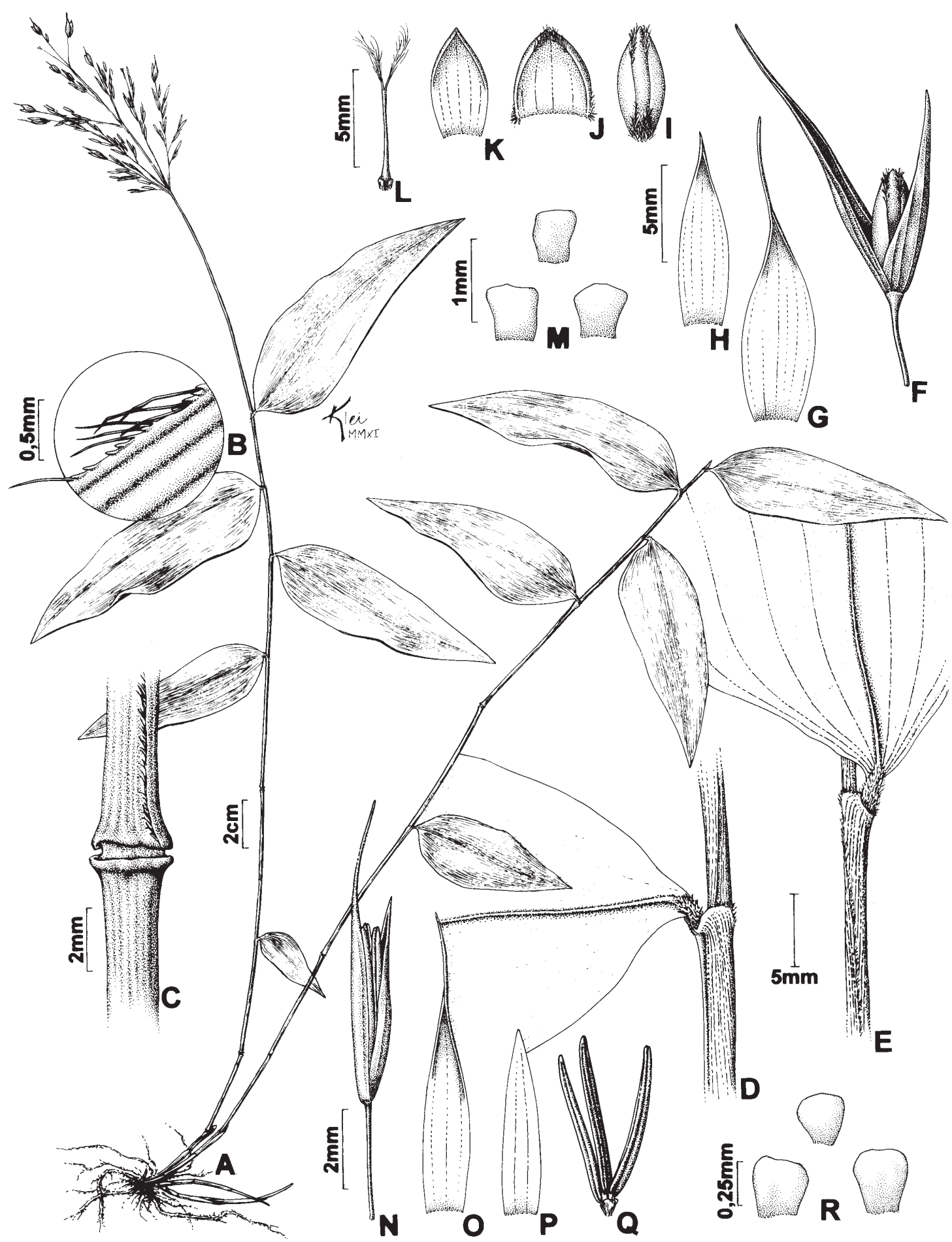

Figura 17. Olyra humilis. A. Hábito. B. Margem da lâmina. C. Nó do colmo. D. Detalhe da face adaxial do pseudopecíolo e da face adaxial da lâmina. E. Detalhe da face abaxial do pseudopecíolo e da face abaxial da lâmina. F. Espigueta feminina. G. Gluma I. H. Gluma II. I. Antécio. J. Lema. K. Pálea. L. Flor feminina. M. Lodículas da flor feminina. N. Espigueta masculina. O. Lema. P. Pálea. Q. Flor masculina. R. Lodículas da flor masculina. (R.T. Shirasuna 2617).

Figure 17. Olyra humilis. A. Habit. B. Edge of the blade. C. Node of the culm. D. Detail of the adaxial face of the pseudopeciole and the adaxial side of the blade. E. Detail of the abaxial face of the pseudopeciole and the abaxial side of the blade. F. Female spikelet. G. Glume I. H. Glume II. I. Anthoecium. J. Lemma. K. Palea. L. Female flower. M. Lodicules of the female flower. N. Male spikelet. O. Lemma. P. Palea. Q. Male flower. R. Lodicules of the male flower. (R.T. Shirasuna 2617). 
restante glabra; estigmas plumosos; lodículas 0,5-0,8 $\mathrm{mm}$ compr., margem inteira, glabras. Espiguetas masculinas 6,5-8(-10) $\mathrm{mm}$ compr., lanceoladas; lema 4-5 mm compr., 3-nervado, vináceo, glabro, arista escabra, arista 1-3 mm, geniculada; pálea 5-6(-8) mm compr., 2-nervada, vinácea, glabra, aguda; lodículas 0,1-0,3 mm compr., margem inteira, glabras; anteras 3,5-5 $\mathrm{mm}$ compr., acastanhadas. Cariopse $5 \times 2,8 \mathrm{~mm}$, elíptica, hilo atingindo o tamanho da cariopse, castanha.

Material examinado: BRASIL. São PAUlo: São Paulo, Parque Estadual das Fontes do Ipiranga, IBt, 9-I-1965, fl., W.D. Clayton \& G. Eiten 4186 (SP); IBt, 7-XII-1931, fl., F.C. Hoehne s.n. (SP28592); IBt, 4-XI-2009, fl., R.T. Shirasuna 2617 (SP).

Ocorre no nordeste da Argentina, Paraguai e Brasil em ambiente florestal, em orla de mata, sub-bosque e capoeira úmida (Oliveira \& LonghiWagner 2001). No Brasil, ocorre nos domínios da Caatinga, Cerrado e Mata Atlântica com distribuição conhecida nas regiões nordeste (BA), centro-norte (DF, GO), sudeste (MG, SP) e sul (PR, RS) (Filgueiras \& Oliveira 2012a). No PEFI foi coletada em oito pontos, em floresta em estádio sucundário inicial, médio e tardio. É uma espécie de ocorrência rara e restrita. Faz parte do sub-bosque natural das florestas, podendo ser eventualmente usada para a restauração de áreas degradadas, desde que haja abundância de mudas ou cariopses.

Conhecida como taquinha (Filgueiras \& SantosGonçalves 2006)

Coletada fértil o ano todo com maiores frequências nos meses de outubro a março.

A espécie não consta do Livro Vermelho das Espécies Vegetais Ameaçadas do Estado de São Paulo (Mamede et al. 2007), esta avaliação é confirmada no presente estudo.

\subsection{Olyra loretensis Mez, Notizbl. Bot. Gart. Berlin-} Dahlem 7(63): 47.1917.

\section{Figura 18}

Rizoma curto. Colmos dimórficos: vegetativos 30-60 cm alt., arqueados a reptantes, geniculadosascendentes, formando densas moitas; entrenós 7,5-13(-20) cm compr., cilíndricos, fistulosos, curtopubescentes, castanho-esverdeados, não maculados. Linha nodal pouco espessada, negra, híspida a pubescente. Folhas de ramo: dos nos basais consistindo somente de bainha ou com lâmina rudimentar; bainha $6-6,5 \times 0,8-1 \mathrm{~cm}$, esparsamente papiloso- piloso com tricomas curtos, caducos e apressos, margem ciliolada mais densa em direção ao ápice; pseudopecíolo 2-3 mm compr., densamente piloso em ambas as faces; lígula externa nula; lígula interna 0,5-1 mm compr., membranoso-ciliolada; lâmina 10-13(-17) $\times(2,2-)-4,7-5,2 \mathrm{~mm}$, lanceolada a ovallanceolada, patente a deflexa, face adaxial glabra, face abaxial pilosa em direção à base e restante escabra, base assimétrica, curtamente ciliolada, truncada, ápice acuminado. Colmos reprodutivos com bainhas ca. $9 \times 1,5 \mathrm{~cm}$, estramineas a violáceas, fortemente estriadas e sobrepostas, glabras a esparsamente pilosas, lâminas nulas. Panículas (7-)9-10(-11,5) cm compr., piramidais, laxas, terminais, as jovens incluídas nas bainhas, ramos inferiores verticilados portando apenas espiguetas masculinas, superiores alternos ou opostos com numerosas espiguetas masculinas em longas ramificações terciarias, espigueta feminina terminal e solitária em cada ramo. Espiguetas femininas 11,2-15 mm compr., lanceoladas, glumas desiguais, mais longas que o antécio, antécio fértil 1; gluma I, 7-8 mm compr., 5-9-nervada, esbranquiçada, escabra a esparçamente pilosa em direção ao ápice ou completamente glabra, longo-aristada, arista 7-8 mm compr.; gluma II, 7-11 mm compr., 5-9-nervada, esbranquiçada, escabra a glabra, aristada, arista 1,5-5 mm compr.; estípite curto; antecio 6-8 $\mathrm{mm}$ compr., esbranquiçado, totalmente piloso; lema 6-8 mm compr., 3-nervado, piloso; pálea 5,8-7,8 mm compr., 2-nervada, tricomas na base e ápice; lodículas $0,6-0,7 \mathrm{~mm}$ compr. levemente vascularizadas, duas iguais e uma menor, glabras. Espiguetas masculinas 2-2,5 mm compr., lanceoladas; lema 2-2,5 mm compr., 3-nervado, violáceo, escabro a escabérulo, mucronado; pálea 1,8-2 mm compr., 2-nervada, violácea, escabérula, ápice agudo; lodículas 0,3-0,5 mm compr., margem irregular; anteras 1-1,5 mm compr., amarelo-acastanhadas. Cariopse 4,5 × 2,2 mm, elíptica, hilo tão longo quanto à cariopse, castanha.

Material examinado: BRASIL. São Paulo: São Paulo, Parque Estadual das Fontes do Ipiranga, IBt, 14-III-1967, fl., T. Sendulsky 607 (SP).

Material adicional: BRASIL. AmAPÁ: Serra do Navio, $\mathrm{km} 189$ along railroad track., growing in forest along road subtending railroad, 3-XII-1974, fl., C.E. Calderón 2280 (SP, US). Amazonas: Humaitá, ca. $50 \mathrm{~km}$ ocidente da cidade, mata de terra firme, 28-XI-1977, fl., N.B.M. Brantjes 100503 (UEC). 


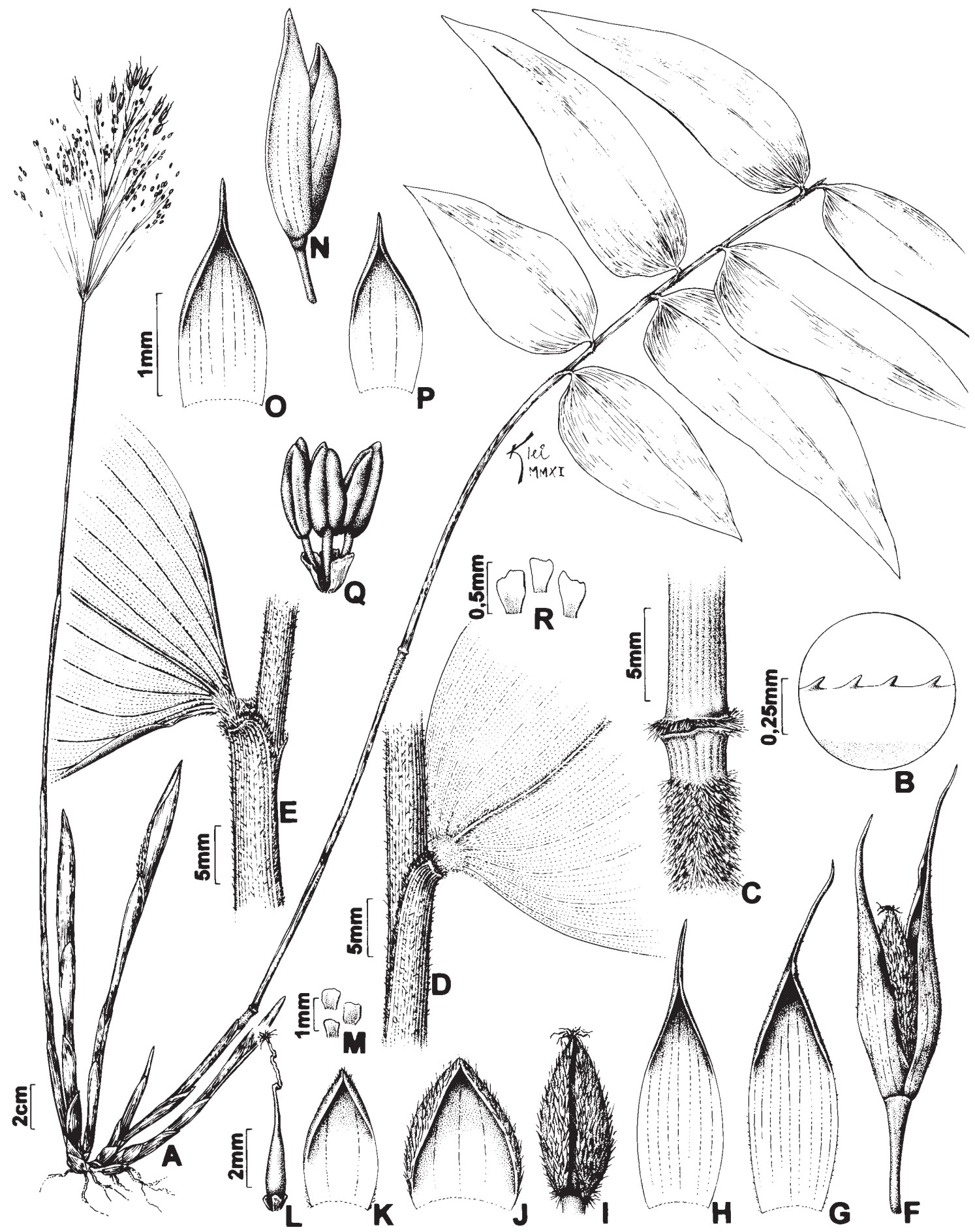

Figura 18. Olyra loretensis. A. Hábito. B. Margem da lâmina. C. Nó do colmo. D. Detalhe da base da face adaxial da lâmina. E. Detalhe do pseudopecíolo e da base da face abaxial da lâmina. F. Espigueta feminina. G. Gluma I. H. Gluma II. I. Antécio. J. Lema. K. Pálea. L. Flor feminina. M. Lodículas da flor feminina. N. Espigueta masculina. O. Lema. P. Pálea. Q. Flor masculina. R. Lodículas da flor masculina. (T. Sendulsky 617).

Figure 18. Olyra loretensis. A. Habit. B. Edge of the blade. C. Node of the culm. D. Detail of the base of the adaxial face of the blade E. Detail of the pseudopecile and the base of the abaxial face of the blade. F. Female spikelet. G. Glume I. H. Glume II. I. Anthoecium. J. Lemma. K. Palea. L. Female flower. M. Lodicules of the female flower. N. Male spikelet. O. Lemma. P. Palea. Q. Male flower. R. Lodicules of the male flower. (T. Sendulsky 617). 
O. loretensis difere de outras espécies de Olyra do PEFI principalmente por ser a única que apresenta dimorfismo entre os colmos vegetativos e reprodutivos. $\mathrm{O}$ colmo vegetativo apresenta folhas com bainha e lâminas bem desenvolvidas e o colmo reprodutivo apenas folhas desprovidas de lâminas. Apresenta sinflorescência masculina vermelhopúrpura contrastando com as espiguetas femininas brancas possivelmente adaptadas para atrair o inseto polinizador (Judziewicz et al. 1999).

Faz parte do grupo informal das espécies de Olyra que apresenta o antécio feminino totalmente recoberto por tricomas como: O. amapana Soderstr. \& Zuloaga, O. bahiensis R.P.Oliveira \& Longhi-Wagner, $O$. ciliatifolia Raddi e $O$. juruana Mez (Oliveira \& Longhi-Wagner 2005).

Ocorre na Bolívia, Brasil, Colômbia e Peru. No Brasil é conhecida no domínio da Amazônia com distribuição para a região norte (AM, AP, PA, RO) (Filgueiras \& Oliveira 2012a), sendo este o primeiro registro para a região sudeste. Por não ter sido coletada novamente no PEFI, apesar da intensidade de coletas na área, permanece ainda uma dúvida residual sobre a autenticidade da procedência do material aqui citado. Entretanto os autores acreditam que a coleta foi realizada por um especialista em Poaceae (T. Sendulsky) por apresentar abundante material (três duplicatas) vegetativo (rizomas adultos, jovens e folhas completas) e florífero (inflorescências jovens e adultas). Além do mais, a troca de rótulo não é provável, pois a Sra. Sendulsky nunca coletou nos estados do Amapá e Amazônia, estados onde há registros de ocorrência da espécie.

Conhecida como taquinha (Filgueiras \& SantosGonçalves 2006).

Registram-se coletas férteis nos meses de março, novembro e dezembro.

Aplicando os critérios do Livro Vermelho das Espécies Vegetais Ameaçadas do Estado de São Paulo (Mamede et al. 2007), é classificada como "criticamente ameaçada".

5. Parodiolyra Soderstr. \& Zuloaga, Smithsonian Contr. Bot. 69: 64. 1989.

Caracteres diagnósticos: colmos monomórficos, panícula laxa, determinada, terminal e/ou axilar; ramos inferiores somente com espiguetas masculinas, os superiores com espiguetas masculinas inferiormente e femininas terminais, ou só espiguetas femininas ou só masculinas, espiguetas unissexuadas, basítonas, espiguetas femininas pouco maiores que as masculinas, pedicelo não espessado no ápice, filiforme, geralmente desarticulando abaixo das glumas, entrenó entre as glumas conspícuo, espessado, antécio fértil 1, estigmas 2 , espiguetas masculinas pouco menores que as femininas.

Parodiolyra é composto por cinco espécies florestais ocorrendo da Costa Rica até o Paraguai e sul do Brasil (Oliveira \& Longhi-Wagner 2001).

No Brasil ocorre nos biomas da Amazonia, Caatinga, Mata Atlântica e Pantanal com distribuição conhecida nas regiões norte (AC, AM, AP, RR), nordeste (AL, BA, MA, PE, SE), centro-oeste (MT, MS), sudeste (ES, MG, RJ, SP) e sul (PR, RS, SC) (Filgueiras \& Oliveira 2012b).

No PEFI registra-se a ocorrência de apenas Parodiolyra micrantha.

5.1. Parodiolyra micrantha (Kunth) Davidse \& Zuloaga, Novon 9: 590. 1999.

Figura 19

Rizoma curto. Colmos monomórficos, 0,5-3 m alt., eretos na base, escandentes a pendentes no ápice, 1-3 ramificações; entrenó (4,0-)5-21(-29) cm compr., cilíndricos, fistulosos, estriados e glabros, verde com ou sem máculas verde-escuras. Linha nodal horizontal, pouco espessada, curtamente pubescente a glabra, negra. Folhas de ramo: bainha 5-11 ×0,5-1,1(-2,4) cm, densamente pubescente a glabra, fortemente estriada, estramínea, esverdeada a vinácea, às vezes com máculas esverdeadas, margem ciliolada, aurícula inconspícua; pseudopecíolo 2-3 mm compr., híspido em ambas as faces, castanho a vináceo; lígula interna (2-)5-10(-15) mm compr., membrano-ciliolada a inteira, superfície adaxial glabra e abaxial esparsamente pubescente a glabra; lâmina $6,5-17 \times 1,3-4,5 \mathrm{~cm}$, ovallanceolada a oblongo-lanceolada, patente, superfície adaxial esverdeada, glabra, ocasionalmente híspida a escabra, superfície abaxial glauca, glabra a híspida, base assimétrica, subcordada a truncada, ápice acuminado, margem curtamente escabra. Panícula 4-20,5 cm compr., piramidal, aberta, difusa, terminal e/ou axilar, os inferiores verticilados somente com espiguetas masculinas, superiores alternos somente com espiguetas femininas ou só masculinas ou só femininas. Pedicelo da espigueta feminina filiforme, escabro a híspido. Espiguetas femininas 4-6 mm compr., ovais; glumas desiguais, mais longas que o antécio, separadas por um entrenó, caindo com o antécio; gluma I, 4-6 mm compr., mais longa 


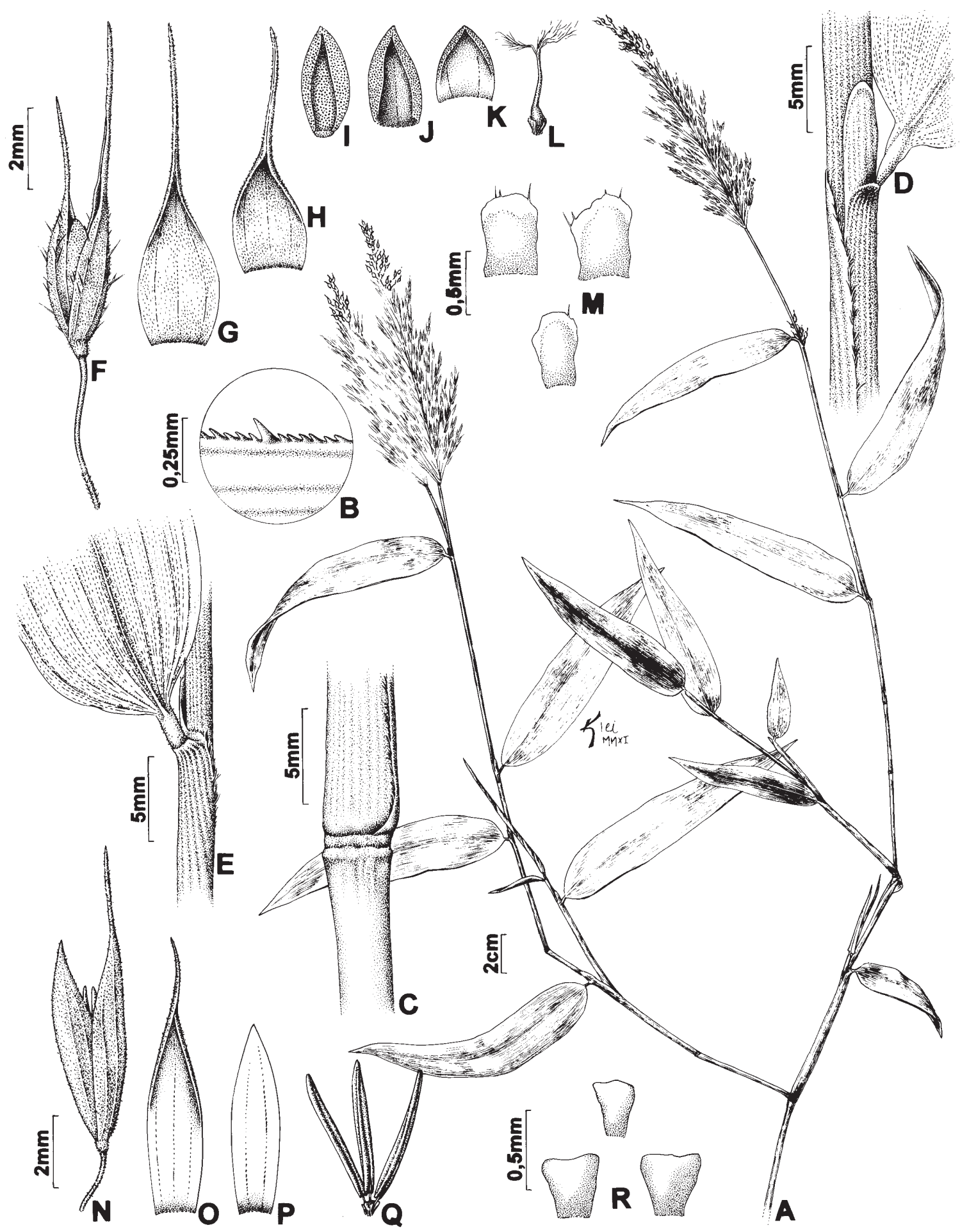

Figura 19. Parodiolyra micrantha. A. Ramo fértil. B. Margem da lâmina. C. Nó do colmo. D. Detalhe da lígula interna. E. Detalhe do ápice da bainha e base da face abaxial da lâmina. F. Espigueta feminina. G. Gluma I. H. Gluma II. I. Antécio. J. Lema. K. Pálea. L. Flor feminina. M. Lodículas da flor feminina. N. Espigueta masculina. O. Lema. P. Pálea. Q. Flor masculina. R. Lodículas da flor masculina. (T. Sendulsky 1038).

Figure 19. Parodiolyra micrantha. A. Fertile branch. B. Edge of the blade. C. Node of the culm. D. Detail of the inner ligule. E. Detail of the sheath apex and the blade base, abaxial face. F. Female spikelet. G. Glume I. H. Glume II. I. Anthoecium. J. Lemma. K. Palea. L. Female flower. M. Lodicules of the female flower. N. Male spikelet. O. Lemma. P. Palea. Q. Male flower. R. Lodicules of the male flower. (T. Sendulsky 1038). 
que a gluma II, raro subiguais, 5-nervada, verdeolivácea, densamente híspida a escabra, aristada, arista 1,5-2(-8) mm; gluma II, 2-5 mm compr., 3-5-nervada, verde-olivácea, densamente híspida a escabra, aristada a subulada, arista 1-4 mm compr.; estípite nulo; antécio 2,5-3,5 mm compr., creme, oliváceo ou acastanhado, foveolado ou pontuado com escavações arredondadas, sem manchas escuras na maturação, escabro em direção ao ápice do lema a completamente glabro; lema 2,5-3 mm compr., 5-nervado; pálea 2,3-2,8 mm compr., 2-nervada; estigmas plumosos; lodículas 0,5-0,6 mm compr., margem inteira a pouco ciliolada, duas iguais e uma um pouco menor. Espiguetas masculinas 5-7 mm compr., lanceoladas, lema 5-7 mm compr., 3-nervado, castanho a vináceo, escabro, aristado, arista 2-3 $\mathrm{mm}$; pálea 4-5 $\mathrm{mm}$ compr., 2-nervada, castanho a vinácea, escabra, aguda a acuminada; lodículas 0,2-0,4 mm compr., margem inteira; anteras 3-3,7 mm compr., castanha. Cariopse $3 \times 2 \mathrm{~mm}$, oblonga, foveolada, castanho-clara.

Material examinado: BRASIL. São PAUlo: São Paulo, Parque Estadual das Fontes do Ipiranga, IBt, 18-XII-1967, fl., C.E. Calderón 2007 (HUEFS, S, SP); IBt, 24-VII-1979, fl., S. A. Corrêa et al. 22 (HUEFS, SP); IBt, 21-II-1976, fl., G. Davidse \& W.G. D'Arcy 10427 (SP); IBt, 1-IX-1976, fl., P.H. Davis \& T. Sendulsky 60395 (UEC); IBt, 23-XI-1966, fl., R. Faria \& O.G. Fonseca s.n. (HUEFS, SP99428); IBt, 18-I-1961, fl., C.G. Fonseca 4 (HUEFS, SP); IBt, 26-IX-1932, fl., F.C. Hoehne s.n. (SP29798); IBt, 25-IX-1945, fl., W. Hoehne 1849 (BHCB, CEPEC, ESA, F, G, HUEFS, IPA, K, MBM, R, SP, SPF, U, UB, UEC, US); IBt, 13-IX-1977, fl., S.L. Jung \& L.M. Barbosa 47 (SP); IBt, 8-XI-1977, fl., S.L. Jung et al. 194 (SP); IBt, 24-X-1977, fl., H. Makino 94 (HUEFS, SP); IBt, 29-VIII-1977, fl., H. Makino 83 (HUEFS, SP); IBt, 18-VIII-1977, fl., M.R.F. Melo 17 (HUEFS, SP); IBt, 5-X-1977, fl., M.R.F. Melo 30 (HUEFS, SP); IBt, 31-I-1979, fl., M.R.F. Melo et al. 123 (HUEFS, SP); IBt, 18-VIII-1977, fl., M.R.F. Melo 19 (HUEFS, SP); IBt, 31-X-1977, fl., M.R.F. Melo 47 (SP); IBt, s.a., fl. T. Sendulsky 1266 (SP); IBt, 13-VIII-1968, fl., T. Sendulsky 1005 (HUEFS, SP); IBt, 13-VIII-1968, fl., T. Sendulsky 805 (HUEFS, SP); IBt, 21-VIII-1968, fl., T. Sendulsky 953 (HUEFS, SP); IBt, 16-XI-1970, fl., T. Sendulsky 1066 (SP); IBt, 13-X-1970, fl., T. Sendulsky 1038 (HUEFS, SP); IBt, 13-VIII-1968, fl., T. Sendulsky 1006 (HUEFS, SP); IBt, 24-VI-2005, fl., R.T. Shirasuna 110 (SP); Cien
Tec , 29-VII-2010, fl., R.T. Shirasuna 2863 (SP); IBt, 19-XI-1963, fl., B. Skvortzov 167 (HUEFS, SP); IBt, 25-VIII-1977, fl., M.S.F. Silvestre 76 (SP); IBt, 25-X-1985, fl., C. Suemitsu 3 (ESA, HUEFS); IBt, 5-X-2007, fl., D. Vinha s.n. (SP398159).

Parodiolyra micrantha apresenta grande amplitude relacionada ao tamanho das plantas, as de menor tamanho entre $0,5-1 \mathrm{~m}$ altura e as mais robustas de até $3 \mathrm{~m}$ altura. No PEFI a grande maioria das plantas é do tipo menos robusto, com até $1 \mathrm{~m}$ altura, crescendo nas margens das matas e em locais mais ensolarados, podendo ser encontrado o tipo robusto com menor frequência no sub-bosque da floresta.

Está amplamente distribuída na América do Sul, ocorrendo nos Andes, Argentina, Bolívia, Brasil, Colômbia, Paraguai e Venezuela, em fragmentos de floresta atlântica secundária, margens de florestas e áreas alteradas (Oliveira \& Longhi-Wagner 2001), entre 20 e 1.065 m.s.m. (Renvoize 1984).

No Brasil, ocorre nos domínios da Amazônia, Caatinga e Mata Atlântica com distribuição conhecida nas regiões: norte (AC, AM, PA, RO), nordeste (AL, BA, MA, PE, SE), centro-oeste (MS), sudeste (ES, MG, RJ, SP) e sul (PR, RS, SC) (Filgueiras \& Oliveira 2012b).

No PEFI, foi coletada em 37 pontos, estando amplamente distribuída em todas as regiões. Ocorre preferencialmente em ambiente sombreado, porém também sob alta intensidade luminosa. É uma espécie que pode alastrar-se por vários metros no sub-bosque das florestas, mas faz parte integral do estrato herbáceo e subarbustivo. Eventualmente pode ser indicada para a restauração do sub-bosque das áreas degradadas, devido a rusticidade e rápido desenvolvimento vegetativo.

Conhecida como Taquara (C.G. Fonseca 4), taquari (M. Kuhlmann 188).

Coletada fértil praticamente o ano todo, com maiores incidências nos meses de setembro a janeiro.

A espécie não consta do Livro Vermelho das Espécies Vegetais Ameaçadas do Estado de São Paulo (Mamede et al. 2007), esta avaliação é confirmada no presente estudo.

Com a conclusão do estudo florístico da família Poaceae no PEFI, evidencia-se a importância de duas espécies (Merostachys scandens) endêmica do Estado de São Paulo e do Brasil e (Merostachys burmanii) que, no Estado de São Paulo, é encontrada somente no PEFI. Isto reforça a importância deste fragmento 
de Mata Atlântica inserida em uma das maiores áreas urbanas da maior metrópole da América do Sul. Portanto, esforços são necessários para a preservação e manutenção deste parque que abriga tantas espécies raras e extremamente ameaçadas de extinção.

É importante enfatizar também que os bambus não são elementos estranhos à floresta, ao contrário, são parte integrante dela e participam ativamente dos estádios sucessionais e demais processos ecológicos.

\section{Agradecimentos}

A primeira autora agradece à Profa. Dra. Ana Paula Santos-Gonçalves e ao Prof. Dr. Eduardo L.M. Catharino pelas valiosas contribuições. Ambos os autores agradecem ao Instituto de Botânica pelo apoio no uso da infraestrutura e pelo financiamento do projeto.

\section{Literatura citada}

APG (Angiosperm Phylogny Group) III. 2009. An update of the Angiosperm Phylogeny Group classification for the orders and families of flowering plants: APG III. Botanical Journal of Linnean Society 161: 105-121.

Aragaki, S. 1997. Florística e estrutura de trecho remanescente de floresta no Planalto Paulistano (SP). Dissertação de Mestrado. Universidade de São Paulo, São Paulo.

Barros, F., Mamede, M.C.H., Melo, M.R.F., Lopes, E.A., Jung-Mendançolli, S.L., Kirizawa, M., Muniz, C.F.S., Makino-Watanabe, H., Chiea, S.A.C. \& Melhem, T.S. 2002. A Flora Fanerogâmica do PEFI: composição, afinidades e conservação. Unidade de Conservação que Resiste a Urbanização de São Paulo. Governo do Estado de São Paulo, Secretaria do Estado do Meio Ambiente, São Paulo, pp. 93-110.

Calderón, C.E. \& Soderstrom, T.R. 1980. The genera of Bambusoideae (Poaceae) of the American Continent: keys and comments. Smithsonian Contributions to Botany 44: 1-27.

Clark, L.G. 1995. Diversity and distribuition of the Andean woody bamboos (Poaceae: Bambuseae). In: S.P. Churchil; H. Balslev, E. Forero \& J. Luteyn. Biodiversity and Conservation of Neotropical Montane Forests. New York Botanical Garden, New York, pp. 501-512.

Clark, L.G. 2001. Chusquea. In: H.M. Longhi-Wagner, V. Bittrich, M.G.L. Wanderley \& G.J. Shepherd (orgs.). Poaceae-Flora Fanerogâmica do Estado de São Paulo. Editora Hucitec, São Paulo.
Clark, L.G., Judziewicz, E.J. \& Tyrrell, C.D. 2007. Aulonemia ximenae (Poaceae: Bambusoideae) a new northern Andean specie with fimbriate sheath margins. The Journal of the American Bamboo Society 20: 1-6.

Dutra, J. 1938. Les bambusées de Rio Grande Du Sud. Revista Sudamericana de Botânica 5: 145-152.

Filgueiras, T.S. \& Oliveira, R.P. 2012a. Olyra. In: R.C. Forzza, A. Costa, B.M.T. Walter, J.R. Pirani, M.P. Morim, L.P. Queiroz, G. Martinelli, A.L. Peixoto, M.A.N. Coelho, J.F.A. Baumgratz, J.R. Stehmann, L.G. Lohmann, M. Hopkins. Lista de Espécies da Flora do Brasil. Jardim Botânico do Rio de Janeiro, Rio de Janeiro. http://floradobrasil.jbrj.gov.br/2012/FB013360 (acesso em 9.02.2012).

Filgueiras, T.S., Oliveira, R.P. 2012b. Parodiolyra. In: R.C. Forzza, A. Costa, B.M.T. Walter, J.R. Pirani, M.P. Morim, L.P. Queiroz, G. Martinelli, A.L. Peixoto, M.A.N. Coelho, J.F.A. Baumgratz, J.R. Stehmann, L.G. Lohmann, M. Hopkins. Lista de Espécies da Flora do Brasil. Jardim Botânico do Rio de Janeiro, Rio de Janeiro. http://floradobrasil.jbrj.gov.br/2010/FB013424 (acesso em 9.02.2012)

Filgueiras, T.S. \& Santos Gonçalves, A.P. 2004. A Checklist of the basal grasses and bamboos in Brazil (Poaceae). The Journal of the American Bamboo Society 18: 7-18.

Filgueiras, T.S. \& Santos-Gonçalves, A.P. 2006. Bambus Nativos no Brasil: Oportunidades e Desafios para seu Conhecimento. In: Anais do I Seminário Nacional do Bambu, Estrutura da Rede de Pesquisa e Desenvovimento, Brasília, DF pp. 33-42.

Filgueiras, T.S. \& Shirasuna, R.T. 2009. Redescoberta de espécies presumivelmente extintas de Poaceae da Flora de São Paulo, Brasil. Hoehnea 36: 507-509.

Filgueiras, T.S., Longhi-Wagner, H.M., Viana, P.L., Zanin, A., Guglieri, A., Oliveira, R.C., Canto-Dorow, T.S., Shirasuna, R.T., Valls, J.F.M. \& Oliveira, R.P. 2012. Poaceae. In: R.C. Forzza, A. Costa, B.M.T. Walter, J.R. Pirani, M.P. Morim, L.P. Queiroz, G. Martinelli, A.L. Peixoto, M.A.N. Coelho, J.F.A. Baumgratz, J.R. Stehmann, L.G. Lohmann, M. Hopkins. Lista de Espécies da Flora do Brasil. Jardim Botânico do Rio de Janeiro, Rio de Janeiro. http://floradobrasil.jbrj.gov. br/2012/FB000193 (acesso em 6.02.2012).

Fisher, A.E., Triplett, J.K., Ho, C.S., Schiller, A.D., Oltrogge, K.A., Schrodewr, E.S., Kelchner, S.A. \& Clark, L.G. 2009. Paraphyly in the bamboo subtribe Chusqueainae (Poaceae: Bambusoideae) and a revised infrageneric classification for Chusquea. Sytematic Botany 34: 673-683.

Gibson, D.J. 2009. Grasses and grassland ecology. Oxford University Press, New York. 
Gomes, E.P.C. 1992. Fitossociologia do componente arbóreo de um trecho de mata em São Paulo. Dissertação de Mestrado. Universidade de São Paulo, São Paulo.

Gomes, E.P.C. 1998. Dinâmica do componente arbóreo de um trecho de mata em São Paulo, SP. Tese de Doutorado. Universidade de São Paulo, São Paulo.

GPWG (Grass Phylogeny Working Group). 2001. Phylogeny and subfamilialclassification of the grasses (Poaceae).Annals of the Missouri Botanical Garden 88: 373-457.

IBGE \& MMA. 2004. IBGE lança o mapa de biomas do Brasil e o mapa de vegetação do Brasil, em comemoração ao dia mundial da biodiversidade. http://www.ibge.gov. br/home/presidencia/noticias/21052004biomas.shtm (acesso em 26.10.2010).

Judziewicz, E.J., Clark, L.G., Londoño, X \& Stern, M. 1999. American Bamboos. Smithsonian Institution, Washington, D.C.

Judziewicz, E.J., Soreng, R.J., Davidse, G., Peterson, P.M., Filgueiras, T.S. \& Zuloaga, F.O. 2000. Catalogue of New World grasses (Poaceae): I. Subfamilies Anomochlooideae, Bambusoideae, Ehrhartoideae and Pharoideae. Contributions from the United States National Herbarium 39: 1-128.

Liebsch, D. \& Reginato, M. 2009. Florescimento e frutificação de Merostachys skvortzovii Sendulsky (taquara-lixa) no Estado do Paraná. Iheringia, série Botânica 64: 53-56.

Longhi-Wagner, H.M., Bittrich, V., Wanderley, M.G.L. \& Shepherd, G.J. 2001. Poaceae. In: M.G.L. Wanderley, G.J. Shepherd, \& A.M. Giulietti (coords.). Flora Fanerogâmica do Estado de São Paulo. v.1, Fapesp, Hucitec, São Paulo.

Mamede, M.C.H., Souza, V.C., Prado, J., Barros, F., Wanderley, M.G.L \& Rando, J.G. 2007. Livro vermelho das espécies vegetais ameaçadas do Estado de São Paulo. Instituto de Botânica, São Paulo.

Mantovani, W. 1993. Estrutura e dinâmica da Floresta Atlântica na Juréia, Iguape, SP. Tese de Livre-Docência, Universidade de São Paulo, São Paulo.

McClure, F.A. 1973. Genera of bamboos native to the New World. Smithsonian Contributions to Botany 9: 1-148.

McClure, F.A. \& Smith, L.B. 1967. Gramíneassuplemento Bambúseas. In: Reitz, P.R. (ed.). Flora Ilustrada Catarinense, Itajaí.

Mori, S.A. Silva, L.A.M. Lisboa, G. \& Coradin, L. 1989. Manual de manejo do herbário fanerogâmico. Centro de Pesquisa do Cacau, Ilhéus.

Nastri, V.D.F., Catharino, E.L.M., Rossi, L., Barbosa, L.M., Pirré, E., Bedinelli, C., Asperti, L.M., Dorta, R.O. \& Costa, M.P. 1992. Estudos fitossociológicos em uma área do Instituto de Botânica de São Paulo utilizados em programas de educação ambiental. J.L. Timoni (ed.). In: Anais do $2^{\circ}$ Congresso Nacional sobre Essências Nativas, Revista do Instituto Florestal, 4: 219-225.
Oliveira, R.P. \& Longhi-Wagner, H.M. 2001. Parodiolyra Soderstr. \& Zuloaga In: H.M. Longhi-Wagner, V. Bittrich, M.G.L. Wanderley \& G.J. Shepherd (eds.). Poaceae-Flora Fanerogâmica do Estado de São Paulo. v.1. Editora Hucitec, São Paulo, pp. 47-48.

Oliveira, R.P. \& Longhi-Wagner, H.M. 2005. Olyra bahiensis (Poaceae-Olyreae): uma nova espécie para a mata atlântica do estado da Bahia, Brasil. Revista Brasileira de Botânica 28: 835-839.

Pivello, V.R. \& Peccinini, A.A. 2002. A Vegetação do PEFI. Parque Estadual das Fontes do Ipiranga. Unidade de Conservação que Resiste a Urbanização de São Paulo. Governo do Estado de São Paulo, Secretaria do Estado do Meio Ambiente, São Paulo, pp. 75-92.

Ponçano, V.L., Carneiro, C.D.R., Bistrich, C.A., Almeida, F.F.M. \& Prandini, F.L. 1981. Mapa geomorfológico do estado de São Paulo: notícia explicativa. São Paulo Instituto de Pesquisas Tecnológicas/PRÓ MINÉRIO/ PROMOCET, pp. 1-94.

Renvoize, S.A. 1984. The grass of Bahia. Royal Botanical Gardens, Kew.

Santos, P.M. \& Funari, F.L. 2002. Clima Local. Parque Estadual das Fontes do Ipiranga. Unidade de Conservação que Resiste a Urbanização de São Paulo. Governo do Estado de São Paulo, Secretaria do Estado do Meio Ambiente, São Paulo, pp. 29-48.

Santos, R.F. (cord.). 2006. Estudos sócio-econômicoecológico e legislativo para caracterização, zoneamento e implantação do Plano de Manejo do Parque Estadual das Fontes do Ipiranga e do seu programa de eco-desenvolvimento: diagnóstico v.1. Laboratório de Planejamento Ambiental - LAPLA/Planejamento Engenharia Agrícola - PLANTEC, Campinas.

Schwarzbach, L.L.C., Negrelle, R.R.B. \& Sanquetta, C.R. 2008. Merostachys skvortzovii Sendulsky: aspectos botânicos e ecológicos-uma revisão. Visão Acadêmica, Curitiba 9: 7-12.

Sendulsky, T. 1992. Merostachys burmanii (Poaceae: Bambusoideae: Bambuseae), a new species from Brazil. Novon 2: 111-114.

Sendulsky, T. 1995. Merostachys multiramea (Poaceae: Bambusoideae: Bambuseae) and similar species from Brazil. Novon 5: 76-96.

Sendulsky, T. 1997. Twelve new species of Merostachys (Poaceae: Bambusoideae: Bambuseae) from Brazil. Novon 7: 285-307.

Sendulsky, T. 2001. Merostachys Spreng. (Poaceae, Bambusoideae, Bambuseae): a new species from Brazil and critical notes on "group speciosa". Kew Bulletin 56: 627-638.

Shirasuna, R.T. 2012a. Chusquea. In: R.C. Forzza, A. Costa, B.M.T. Walter, J.R. Pirani, M.P. Morim, L.P. Queiroz, G. Martinelli, A.L. Peixoto, M.A.N. Coelho, J.F.A. Baumgratz, J.R. Stehmann, L.G. Lohmann, M. Hopkins. Lista de Espécies da Flora do Brasil. Jardim Botânico do Rio de Janeiro, Rio de Janeiro. http:// floradobrasil.jbrj.gov.br/2010/FB013092 (acesso em 22.03.2012). 
Shirasuna, R.T. 2012b. Merostachys. In: R.C. Forzza, A. Costa, B.M.T. Walter, J.R. Pirani, M.P. Morim, L.P. Queiroz, G. Martinelli, A.L. Peixoto, M.A.N. Coelho, J.F.A. Baumgratz, J.R. Stehmann, L.G. Lohmann, M. Hopkins. Lista de Espécies da Flora do Brasil. Jardim Botânico do Rio de Janeiro, Rio de Janeiro. http:// floradobrasil.jbrj.gov.br/2010/FB013316 (acesso em 22.03.2012).

Soderstrom, T.R. \& Young, S.M. 1983. A guide to collecting bamboos. Annals of the Missouri Botanical Garden 70: 128-136.

Soderstrom, T.R., Judziewicz, E.J. \& Clark, L.G. 1988. Distribution patterns in neotropical bamboos. In: Heyer, W.R. \& Vanzolini, P.E. (eds). Proceedings of the Neotropical Biotic Distribution Pattern Workshop, 12-16. Academia Brasileira de Ciências. Rio de Janeiro, pp. 121-157.

Struffaldi-De-Vuono, Y., Lopes, M.I.M.S. \& Domingos,

M. 1984. Poluição atmosférica e elementos tóxicos na Reserva Biológica do Instituto de Botânica, São Paulo, Brasil. Revista Brasileira de Botânica 7: 149-156.
Sungkaew, S., Stapleton, C.M.A., Salamin, N. \& Hodkinson, T.R. 2009. Non-monophyly of the woody bamboos (Bambusoideae; Poaceae): a multi-gene region phylogenetic analysis of Bambusoideae s.s. Journal of Plant Research 122: 95-108.

Thiers, B. 2012. Index Herbariorum: a global directory of public herbaria and associated staff. New York Botanical Garden's Virtual Herbarium. http://sweetgum.nybg.org/ $\mathrm{ih} /$ (Acesso em 1.11.2012).

Viana, P.L. 2010a. Aulonemia. In: R.C. Forzza, A. Costa, B.M.T. Walter, J.R. Pirani, M.P. Morim, L.P. Queiroz, G. Martinelli, A.L. Peixoto, M.A.N. Coelho, J.F.A. Baumgratz, J.R. Stehmann, L.G. Lohmann, M. Hopkins. Lista de Espécies da Flora do Brasil. Jardim Botânico do Rio de Janeiro, Rio de Janeiro. http:// floradobrasil.jbrj.gov.br/2010/FB013022 (acesso em 18.01.2012).

Viana, P.L. 2010b. O gênero Aulonemia Goudot (Poaceae: Bambusoideae: Bambuseae) no Brasil. Tese de Doutorado, Universidade Federal de Minas Gerais, Belo Horizonte. 